\title{
AVALIAÇÃO DA SEMEADURA A LANÇO DE ESPÉCIES FLORESTAIS NATIVAS PARA RECUPERAÇÃO DE ÁREAS DEGRADADAS
}

\author{
DENIS FAQUIM ARAKI
}

Dissertação apresentada à Escola Superior de Agricultura "Luiz de Queiroz", Universidade de São Paulo, para obtenção do título de Mestre em Ecologia de Agroecossistemas.

PIR A C ICAB A

Estado de São Paulo - Brasil

Abril - 2005 


\title{
AVALIAÇÃO DA SEMEADURA A LANÇO DE ESPÉCIES FLORESTAIS NATIVAS PARA RECUPERAÇÃO DE ÁREAS DEGRADADAS
}

\author{
DENIS FAQUIM ARAKI \\ Biólogo
}

Orientador: Prof. Dr. RICARDO RIBEIRO RODRIGUES

Dissertação apresentada à Escola Superior de Agricultura "Luiz de Queiroz", Universidade de São Paulo, para obtenção do título de Mestre em Ecologia de Agroecossistemas.

PIRACICABA

Estado de São Paulo - Brasil

Abril - 2005 
Dados Internacionais de Catalogação na Publicação (CIP) DIVISÃO DE BIBLIOTECA E DOCUMENTAÇÃO - ESALQ/USP

Araki, Denis Faquim

Avaliação da semeadura a lanço de espécies florestais nativas para recuperação de áreas degradadas / Denis Faquim Araki. - - Piracicaba, 2005.

150 p. : il.

Dissertação (mestrado) - - Escola Superior de Agricultura Luiz de Queiroz, 2005.

Bibliografia.

1. Banco de sementes 2. Espécies florestal 3. Plantas nativas 4. Reabilitação de áreas degradadas 5. Semeadura direta I. Título

CDD 634.97

"Permitida a cópia total ou parcial deste documento, desde que citada a fonte - O autor" 
Dedico este trabalho aos meus avós paternos SHISAKI ARAKI (in memoriam) e HATSUME SERIKAWA (in memoriam) e maternos BENJAMIM FAQUIM (in memoriam) e CAROLINA COLOMBO. 


\section{AGRADECIMENTOS}

A FAPESP pela bolsa de estudos concedida e pela reserva técnica, imprescindíveis para a realização deste projeto.

A Cia. Açucareira Vale do Rosário pela área experimental cedida e todo apoio logístico e financeiro, importantíssimos para a realização deste.

Ao Prof. Ricardo Rodrigues pela orientação, amizade, compreensão e confiança. Sem dúvida aprendi muito com suas valiosas palavras. Obrigado pela oportunidade.

Ao Prof. Décio Barbin pela paciência no planejamento estatístico do experimento e inúmeras consultas durante o projeto.

Ao Prof. Carlos Tadeu pelo insight nas análises dos dados finais participação na banca de qualificação.

Ao Prof. Sergius Gandolfi pela participação na banca de qualificação.

Aos amigos da Vale do Rosário, Milton Jarreta e Aluísio Martins pela amizade cativada e por toda ajuda prestada durante o projeto. Muito obrigado mesmo pela atenção e dedicação, sem os quais este projeto não viria a ser concretizado. Valeu Jarretinha e Aluísio.

A amiga Ana pela ajuda no entendimento e no planejamento das análises estatísticas.

Ao amigo Valério pelos conselhos, empréstimos de matérias bibliográficos e dicas de pesquisa.

Aos amigos da República Blue House: Pelé, Gaúcho, Raul, Sandal e Ricardinho, pela convivência e baladas.

Ao Murruga pela paciência na correção da ortografia do trabalho. 
Ao Sô Zé do viveiro pela amizade e dedicação à preservação da natureza através da simplicidade.

Aos amigos do LERF: Alzira, Adriana, Martinha, Vicente, Penúltimo, Pinus, Fá, Vânia, Toco, Fininho, Lucrésia, Córgo, Cris, Xis e Chicão pela amizade e alegres momentos compartilhados.

A Oriza pela motivação e por sua árdua luta na preservação ambiental do campus.

A Tandera pela ajuda na coleta de dados no campo e ao Pedro pela ajuda no projeto de viveiro.

Ao grande amigo Véio pelo reencontro e força nos trabalho.

Aos amigos irmãos Neto e Netim e Édão que mesmo distantes agitam a torcida.

Ao meu primo Carlos Araki pela motivação e palavras sábias.

A galera da República Kama Sutra: Flavião, CPI e ao meu irmão Maicon Araki pela ajuda na coleta de dados no campo, pelo companheirismo, família, motivação e a nossa amada MÚSICA de cada dia que sem dúvida me empenhou a realizar este projeto.

Aos meus queridos amigos da Associação Giatti Karate - Do principalmente ao Sensei Silvio por todas palavras amigas e ensinamentos de filosofia de vida. "Oss"

À minha Mãe Clarice e meu Pai Washington, por todo amor e carinho.

A minha Irmã Cristina e minhas sobrinhas Bruninha e Fernandinha pela motivação nos estudos e carinho durante nossos encontros.

A minha vó Carolina, por todas orações fervorosas e incansáveis, tenho certeza que elas iluminaram minha vida.

Enfim agradeço a Erica que foi companheira de todos os momentos. Muito obrigado linda por toda amizade, paciência, compreensão, carinho e valiosos conselhos durante todo o tempo que compartilhamos juntos. Valeu Gente! 


\section{SUMÁRIO}

Página

LISTA DE FIGURAS ................................................................. viii

LISTA DE TABELAS .................................................................. ix

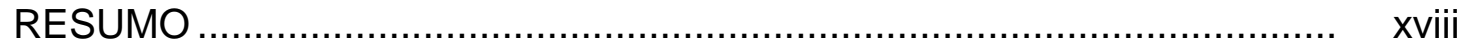

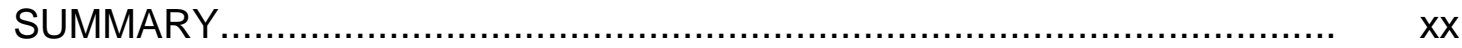

1 INTRODUÇÃO ............................................................................... 1

2 REVISÃO DE LITERATURA....................................................... 5

2.1 Bases e conceitos da disciplina recuperação de áreas degradadas...... 5

2.1.1 O desenvolvimento de métodos para restauração florestal ................ 8

2.1.2 Métodos de recomposição florestal .............................................. 12

2.1.2.1 Regeneração artificial por semeadura direta de espécies florestais . $\quad 14$

2.1.2.1.1 Métodos de semeadura direta ............................................. 18

2.1.2.2 Implicações do uso da semeadura direta de espécies florestais .... $\quad 19$

2.1.2.2.1 Regiões temperadas ..................................................... 20

2.1.2.2.2 Regiões tropicais ..................................................... 22

2.1.2.3 Semeadura direta de espécies florestais nativas no Brasil........... 27

2.1.2.4 Semeadura direta versus plantio de mudas.............................. 36

3 MATERIAS E MÉTODOS ......................................................... 39

3.1 Área de implantação do projeto .................................................. 39

3.2 Escolha das espécies florestais ........................................... 40

3.3 Instalação e condução dos experimentos......................................... 41

3.4 Experimento "A" .................................................................. 43

3.4.1 Preparação do sítio de plantio ..................................................... 50

3.4.2 Tratos culturais ..................................................................... 51 
3.4.3 Densidade de sementes por espécies ................................... 55

3.5 Experimento "B" ....................................................... 58

3.5.1 Experimento de campo ................................................... 58

3.5.1.1 Densidade de sementes por espécies ..................................... 60

3.5.1.2 Preparo do sítio de plantio ................................................. 62

3.5.2 Controle da germinação em sementeiras .................................... 64

3.6 Avaliação da emergência e sobrevivência das espécies florestais....... 66

3.6.1 Experimento "A" ............................................................. 66

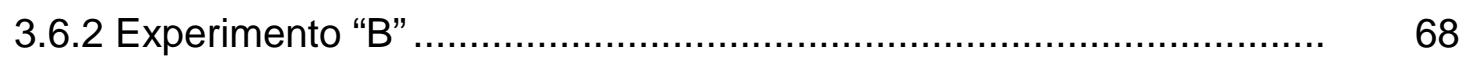

3.6.2.1 Experimento de campo e em viveiro ..................................... 68

4 RESULTADOS E DISCUSSÃO .................................................... 69

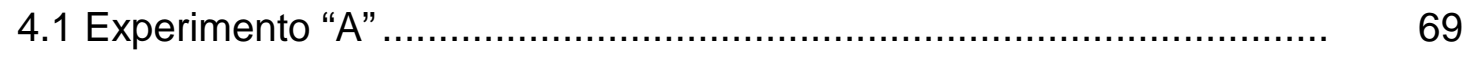

4.1.1 Emergência de plântulas................................................... 70

4.1.2 População final ......................................................................... 72

4.1.3 Platypodium elegans................................................................ $\quad 74$

4.1.4 Pterogyne nitens ................................................................ 81

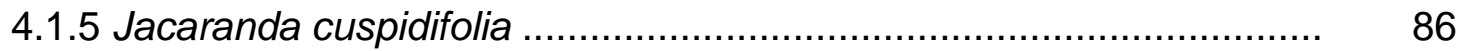

4.1.6 Possíveis causas da não emergência das outras espécies florestais semeadas neste experimento .................................................... 93

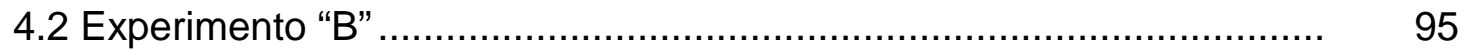

4.3 Consideração sobre a viabilidade metodológica e econômica da técnica utilizada...................................................................................... 98



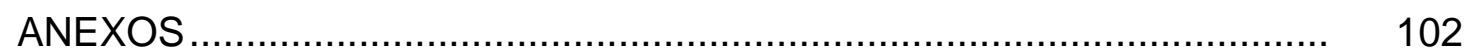

REFERÊNCIAS BIBLIOGRÁFICAS.............................................. 124 


\section{LISTA DE FIGURAS}

1 Esquema de implantação dos tratamentos e

Página testemunhas nas parcelas de acordo com 0 delineamento experimental de blocos casualizados, do experimento " $A$ " do projeto de semeadura direta. Fazenda Paineiras, Morro Agudo, SP

2 Parcela onde foi utilizado esterco bovino, em destaque distribuição uniforme usando rastelo de jardinagem, no experimento " $A$ " do projeto de semeadura direta. Fazenda Paineiras, Morro Agudo, $\mathrm{SP}$

3 Distribuição a lanço do superfosfato simples nas respectivas parcelas do experimento " $A$ " do projeto de semeadura direta. Fazenda Paineiras, Morro Agudo, SP

4 Implantação das parcelas na área do experimento "A" do projeto de semeadura direta após o preparo do solo. Fazenda Paineiras, Morro Agudo, SP 
5 Semeadura a lanço das espécies florestais na parcela do experimento " $A$ " do projeto de semeadura direta. Fazenda Paineiras, Morro Agudo, SP

6 Incorporação das sementes ao solo na parcela do experimento " $A$ " do projeto de semeadura direta, em destaque o soquete de madeira utilizado, Fazenda Paineiras, Morro Agudo, SP

7 Aspecto geral da área do experimento " $A$ " do projeto de semeadura direta após o preparo do solo. Fazenda Paineiras, Morro Agudo, SP

8 a) Coroamento e estaqueamento de plântulas com estaca de bambu e b) Aspecto de uma plântula coroada e marcada, para facilitar o controle de competidores no experimento " $A$ " do projeto de semeadura direta. Fazenda Paineiras, Morro Agudo, $\mathrm{SP}$

9 Plântula protegida para aplicação do herbicida glifosate no experimento " $A$ ", em destaque o protetor físico (garrafa plástica), no projeto de semeadura direta. Fazenda Paineiras, Morro Agudo, SP

10 Precipitação diária dos meses fevereiro, março, abril e maio do ano de 2003 emitida pelo pluviômetro instalado na Usina Vale do Rosário, Orlândia, SP, 8 $\mathrm{km}$ aproximado em linha reta da área experimental do projeto de semeadura direta 
11 Índice pluviométrico mensal relativo a 1 ano após a implantação do experimento em campo, emitido pelo pluviômetro instalado na Usina Vale do Rosário, Orlândia, SP, $8 \mathrm{~km}$ aproximado em linha reta da área experimental do projeto de semeadura direta.

12 Aspecto geral da área do experimento "B" do projeto de semeadura direta durante o preparo do solo com gradagem leve. Fazenda Paineiras, Morro Agudo, SP

13 Esquema de implantação dos tratamentos e testemunhas nas parcelas de acordo com o delineamento experimental de blocos casualizados, do experimento "B" do projeto de semeadura direta. Fazenda Paineiras, Morro Agudo, SP

14 Precipitação diária dos 5 primeiros meses do ano de 2004 emitida pelo pluviômetro instalado na Usina Vale do Rosário, Orlândia, SP, 8 km aproximado em linha reta da área experimental do projeto de semeadura direta

15 Incorporação das sementes ao solo na parcela do experimento "B" do projeto de semeadura direta, em destaque o rolete de metal utilizado. Fazenda Paineiras. Morro Agudo, SP.

16 Área do experimento "B" do projeto de semeadura direta sendo preparada para implantação, em destaque as parcelas do experimento "A" ao fundo. Fazenda Paineiras, Morro Agudo, SP 
17 Aplicação do herbicida pré-emergente nas parcelas do experimento "B", destacando-se a barra utilizada para a pulverização do produto, no projeto de semeadura direta. Fazenda Paineiras, Morro Agudo, SP

18 Sementeira vista de cima com as sementes distribuídas, montada em viveiro para acompanhamento do experimento "B" do projeto de semeadura direta. Viveiro BioFlora, Piracicaba - SP

19 Indivíduos emergentes (a) Jacaranda cuspidifolia Mart. e (b) Platypodium elegans Vog. vistos de cima na parcela do experimento "A", aos 90 dias após a semeadura no projeto de semeadura direta. Fazenda Paineiras, Morro Agudo, SP

20 Indivíduos emergentes (a) Jacaranda cuspidifolia Mart e (b) Pterogyne nitens Tul., na parcela do experimento " $A$ " aos 120 dias após a semeadura, no projeto de semeadura direta. Fazenda Paineiras, Morro Agudo, SP.

21 Aspecto geral da área do experimento "A", um ano após a semeadura, no projeto de semeadura direta. Fazenda Paineiras, Morro Agudo, SP 
22 Médias de porcentagens de emergência e erro padrão para $P$. elegans no grupo $P$ (preenchimento), no grupo $\mathrm{P}+\mathrm{D}$ (preenchimento e diversidade) aos 90 e 360 dias após a semeadura (DAS) do experimento "A" do projeto de semeadura direta.

23 Médias de porcentagens de emergência para $P$. nitens no grupo $\mathrm{P}$ (preenchimento) e no grupo $\mathrm{P}+\mathrm{D}$ (preenchimento e diversidade) aos 90 e 360 dias após a semeadura (DAS) do experimento "A" do projeto de semeadura direta.

24 Médias de porcentagens de emergência para $J$. cuspidifolia no grupo P (preenchimento) e no grupo $\mathrm{P}+\mathrm{D}$ (preenchimento e diversidade) aos 90 e 360 dias após a semeadura (DAS) do experimento "A" do projeto de semeadura direta.

25 Porcentagens de emergência para as espécies testadas no experimento " $\mathrm{B}$ " em condições de viveiro do projeto de semeadura direta 


\section{LISTA DE TABELAS}

1 Descrição dos fatores e seus respectivos níveis

Página utilizados para o experimento " $A$ " do projeto de semeadura direta. Fazenda Paineiras, Morro Agudo, $\mathrm{SP}$

2 Relação das espécies florestais e respectivas densidades de sementes do grupo de preenchimento utilizadas no experimento " $A$ " no projeto de semeadura direta. Fazenda Paineiras, Morro Agudo, SP

3 Relação das espécies florestais e respectivas densidades de sementes do grupo de diversidade utilizadas no experimento "A" no projeto de semeadura direta. Fazenda Paineiras, Morro Agudo, $\mathrm{SP}$

4 População total das espécies florestais emergidas após 360 dias pós - semeadura no experimento "A" do projeto de semeadura direta $(\mathrm{P}=$ preenchimento, $\mathrm{D}=$ diversidade e $\mathrm{P}+\mathrm{D}=$ preenchimento + diversidade). 
5 Valores médios de porcentagem de emergência das plântulas da espécie Platypodium elegans estudada no grupo de preenchimento $(P)$, aos 90 dias após a semeadura, nas diferentes condições testadas (NPel - sementes não peletizadas, Pel - sementes peletizadas, CIN - com incorporação da semente ao solo, SIN - sem incorporação da semente ao solo)

6 Valores médios de porcentagem de emergência das plântulas da espécie Platypodium elegans estudada no grupo de preenchimento $(P)$, aos 360 dias após a semeadura, nas diferentes condições testadas (NPel - sementes não peletizadas, Pel - sementes peletizadas, CIN - com incorporação da semente ao solo, SIN - sem incorporação da semente ao solo)

7 Valores médios de emergência das plântulas da espécie Platypodium elegans estudada no grupo preenchimento + diversidade $(P+D)$, aos 90 dias após a semeadura, nas diferentes condições testadas (NPel - sementes não peletizadas, Pel sementes peletizadas, CIN - com incorporação da semente ao solo, SIN - sem incorporação da semente ao solo). 
8 Valores médios de emergência das plântulas da espécie estudada Platypodium elegans no grupo preenchimento + diversidade $(P+D)$, aos 360 dias após a semeadura, nas diferentes condições testadas (NPel - sementes não peletizadas, Pel sementes peletizadas, CIN - com incorporação da semente ao solo, SIN - sem incorporação da semente ao solo)

9 Valores médios de porcentagem de emergência das plântulas da espécie Pterogyne nitens estudada no grupo de preenchimento $(\mathrm{P})$, aos 90 dias após a semeadura, nas diferentes condições testadas (NPel - sementes não peletizadas, Pel - sementes peletizadas, CIN - com incorporação da semente ao solo, SIN - sem incorporação da semente ao solo)

10 Valores médios de porcentagem de emergência das plântulas da espécie Pterogyne nitens estudada no grupo de preenchimento $(P)$, aos 360 dias após a semeadura, nas diferentes condições testadas (NPel - sementes não peletizadas, Pel - sementes peletizadas, CIN - com incorporação da semente ao solo, SIN - sem incorporação da semente ao solo) 
11 Valores médios de emergência das plântulas da espécie Pterogyne nitens estudada no grupo preenchimento + diversidade $(P+D)$, aos 90 dias após a semeadura, nas diferentes condições testadas (NPel - sementes não peletizadas, Pel sementes peletizadas, CIN - com incorporação da semente ao solo, SIN - sem incorporação da semente ao solo).

12 Valores médios de emergência das plântulas da espécie estudada, Pterogyne nitens no grupo preenchimento + diversidade $(P+D)$, aos 360 dias após a semeadura, nas diferentes condições testadas (NPel - sementes não peletizadas, Pel sementes peletizadas, CIN - com incorporação da semente ao solo, SIN - sem incorporação da semente ao solo)

13 Valores médios de emergência das plântulas da espécie Jacaranda cuspidifolia estudada no grupo de diversidade (D), aos 90 dias após a semeadura, nas diferentes condições testadas (NPel - sementes não peletizadas, Pel - sementes peletizadas, CIN com incorporação da semente ao solo, SIN - sem incorporação da semente ao solo) 
14 Valores médios de emergência das plântulas da espécie estudada Jacaranda cuspidifolia no grupo de diversidade (D), aos 360 dias após a semeadura, nas diferentes condições testadas (NPel - sementes não peletizadas, Pel - sementes peletizadas, CIN com incorporação da semente ao solo, SIN - sem incorporação da semente ao solo)

15 Valores médios de emergência das plântulas da espécie Jacaranda cuspidifolia estudada no grupo preenchimento + diversidade $(P+D)$, aos 90 dias após a semeadura, nas diferentes condições testadas (NPel - sementes não peletizadas, Pel sementes peletizadas, CIN - com incorporação da semente ao solo, SIN - sem incorporação da semente ao solo)

16 Valores médios de emergência das plântulas da espécie estudada Jacaranda cuspidifolia no grupo preenchimento + diversidade $(P+D)$, aos 360 dias após a semeadura, nas diferentes condições testadas (NPel - sementes não peletizadas, Pel sementes peletizadas, CIN - com incorporação da semente ao solo, SIN - sem incorporação da semente ao solo) 


\section{AVALIAÇÃO DA SEMEADURA A LANÇO DE ESPÉCIES FLORESTAIS NATIVAS PARA RECUPERAÇÃO DE ÁREAS DEGRADADAS}

Autor: DENIS FAQUIM ARAKI

Orientador: Prof. Dr. RICARDO RIBEIRO RODRIGUES

\section{RESUMO}

Através da semeadura de espécies nativas de diferentes grupos ecológicos, será possível levantar dados sobre a constituição, o adensamento e o enriquecimento do banco de sementes como uma possível prática de recuperação de áreas degradadas, principalmente visando: 1) o primeiro recobrimento do solo; 2) o possível enriquecimento da área (aumento do número de espécies) com a semeadura direta. $\mathrm{O}$ objetivo geral desse trabalho foi analisar a viabilidade metodológica da constituição artificial de banco de sementes de espécies florestais nativas, como estratégia de recuperação de áreas degradadas. Este trabalho teve como objetivos específicos: i) Estudar espécies potenciais para uso de semeadura direta de espécies nativas em áreas degradadas, quanto à emergência de plântulas e se, o número de indivíduos estabelecidos após um ano da semeadura é suficiente para ocupação florestal de uma área degradada; ii) Avaliar diferentes condições (tratamentos) da semeadura a lanço de espécies florestais nativas para potencializar a emergência de plântulas. Foram realizados neste trabalho dois experimentos em períodos diferentes. O experimento "A" foi instalado em fevereiro de 2003, em delineamento de blocos casualizados (DBC) e 36 tratamentos com 3 
repetições, resultando em 108 parcelas em esquema fatorial $(3 \times 2 \times 3 \times 2)$ objetivando testar 20 espécies florestais, sendo 10 pertencentes ao grupo de preenchimento e 10 pertencentes ao grupo de diversidade. O experimento "B" foi instalado em janeiro de 2004, em blocos casualizados (DBC) e 4 tratamentos com oito repetições, resultando em 32 parcelas em esquema fatorial (2x2) objetivando testar 20 espécies florestais do grupo de preenchimento. Neste experimento as sementes das espécies florestais nativas (20 espécies) além de semeadas no campo tiveram também sua germinação testada em sementeiras no viveiro para posterior comparação com a germinação das espécies em condições de campo. De acordo com os resultados obtidos a método mostrouse viável conseguindo nesse experimento, aos 360 dias após a semeadura até 874 indivíduos ha ${ }^{-1}$ no grupo de preenchimento (4 espécies) e 1902 indivíduos ha $^{-1}$ no grupo de diversidade (7 espécies) no experimento "A". As espécies do grupo de preenchimento Platypodium elegans e Pterogyne nitens e a do grupo de diversidade Jacaranda cuspidifolia foram as que mais se destacaram no experimento "A" com 292, 318, 574 indivíduos ha $^{-1}$ respectivamente. Embora as espécies no experimento "B" não tenham germinado em condições de campo, seus dados de germinação em sementeiras no viveiro demonstraram que as sementes estavam viáveis, exceto Cecropia pachystachya. Os fatores ambientais em condições de campo contribuíram para a não germinação de sementes das espécies florestais estudadas neste experimento ("B"), principalmente a competição com Brachiaria decumbens. Isso demonstra que o manejo desta gramínea pós-semeadura é fundamental para o sucesso deste método.

Palavras chaves: semeadura direta; restauração florestal; recuperação de áreas degradadas; ocupação florestal; espécies nativas. 


\title{
EVALUATION OF THE THROWING SOWING OF NATIVE FOREST SPECIES FOR RECOVERY OF DEGRADED AREAS
}

\author{
Author: DENIS FAQUIM ARAKI
}

Adviser: Prof. Dr. RICARDO RIBEIRO RODRIGUES

\section{SUMMARY}

Through the sowing of native species of different ecological groups, it will be possible to raise information on the constitution, the growing and enrichment of the bank of seeds as possible practical of recovery of degraded areas, mainly aiming at: 1) the first covering of the ground; 2) the possible enrichment of the area (increase of the species number) with the direct sowing. The general objective of this work was to analyze the methodological viability of the artificial constitution of bank of seeds of native forest species, as strategy of recovery of degraded areas. This work had as objective specific: A) To study the potential species for use of direct sowing of native species in degraded areas, how much to the emergency of seedlings and if the number of individuals established after one year of the sowing is enough for forest occupation of a degraded area; $\mathrm{B}$ ) to determine different conditions (treatments) of the throwing sowing of native forest species to increase the emergency of seedlings. Two experiments in different periods had been carried through in this work. The experiment "A" was installed in February of 2003, in a randomized blocks design with 36 treatments and 3 repetitions, resulting in 108 parcels in factorial project

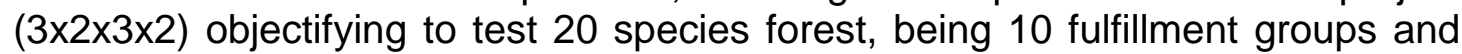
10 diversity groups. The experiment "B" was installed in February of 2003 with a randomized blocks design and 4 treatments with eight repetitions, resulting in 32 parcels in factorial project $(2 \times 2)$ objectifying to test 20 
forest pioneer species. In this experiment the seeds of the native forest species (20 species) beyond sown in the field had also its germination tested in nursery, for posterior comparison with the germination of the species in field conditions. In accordance with the gotten results the methodology revealed viable obtaining in the " $A$ " experiment, to the 360 days after the sowing up to 874 individuals ha ${ }^{-1}$ of fulfillment groups (4 species) and 1.902 individuals ha $^{-1}$ of diversity groups (7 species). The Platypodium elegans and Pterogyne nitens of fulfillment groups and of the diversity groups Jacaranda cuspidifolia had been the more distinguished in the experiment " $A$ " with 292, 318, 574 individuals ha ${ }^{-1}$ respectively. Although the species in experiment "B" have not germinated in field conditions, its germination data in nursery had demonstrated that the seeds were viable, except Cecropia pachystachya. The ambient factors in field conditions had been the causers of this ungermination seeds of the studied forest species, mainly competition with Brachiaria decumbens. This results demonstrates that the handling of this grassy after-sowing is basic for the success of this methodology.

Keys words: direct sowing; forest restoration; degraded areas recovery; forest occupation; native species. 


\section{INTRODUÇÃO}

A expansão econômica mundial no século $X X$ promoveu uma intensa ocupação de áreas, causando com isso, grandes perturbações ao meio ambiente pela intensa fragmentação de biomas.

Entre os principais fatores de degradação de ambientes terrestres estão: os desmatamentos para fins de agricultura, a urbanização, as obras de engenharia para construção de estradas, ferrovias ou represas, a mineração a céu aberto, a super exploração da vegetação, as práticas agrícolas inadequadas, tal como o uso excessivo de produtos químicos, o uso de máquinas inadequadas, a ausência de práticas conservacionistas do solo e as atividades industriais ou bioindustriais que causam a poluição do solo (Dias \& Griffith, 1998).

No Brasil, a conseqüente fragmentação de paisagens por estas atividades constitui uma das mais marcantes interferências ambientais causadas pelo homem. Este processo teve início com a colonização, sendo intensificado neste último século. O uso e a ocupação desordenada tal como tem ocorrido, em todo território brasileiro tanto para exploração agrícola como para expansão de áreas urbanas e industriais tem acarretado preocupações com o uso dos recursos naturais por estas e pelas futuras gerações para a sociedade como um todo (Barbosa \& Mantovani, 2000).

Devido à expansão agropecuária, representada pela cana-de-açúcar, laranja, reflorestamentos homogêneos e pastagens, atualmente restam apenas $7,16 \%$ da cobertura natural do Estado de São Paulo (Fundação SOS Mata Atlântica \& Instituto Nacional de Pesquisas Espaciais, 1992). Por isso espécies 
nativas têm chamado a atenção dos reflorestamentos como meio de recompor as áreas degradadas.

Assim, a necessidade de se recuperar o meio ambiente vem sendo a cada dia uma discussão pertinente pela real situação na qual se encontram os ecossistemas brasileiros.

A recuperação de áreas degradadas é uma prática muito antiga, podendo-se encontrar exemplos de sua existência na história de diferentes povos, épocas e regiões. No entanto, até recentemente ela se caracterizava como uma atividade sem vínculos estreitos com concepções teóricas, sendo executada normalmente como uma prática de plantio de mudas, com objetivos muito específicos, como controle de erosão, estabilização de taludes, melhoria visual, entre outros (Rodrigues, 1999). Esta recuperação é limitada a uma série de fatores naturalmente controlados pelas condições do ambiente, sendo bastante variável o efeito que o conjunto de técnicas restauradoras, pode proporcionar (Abrahão \& Mello, 1998).

As interferências humanas em áreas alteradas, buscando restabelecer os processos ecológicos e, portanto a integridade ecológica dessas com vegetação natural, requerem esforços diferenciados, dependentes da história de degradação de cada situação do mosaico ambiental e das características de seu entorno, expressando sua resiliência ou capacidade de auto-recuperação (Rodrigues \& Gandolfi, 2000).

Embora existam muitas metodologias que instrumentalizam o objetivo de restaurar um ecossistema florestal ou subtropical, uma abordagem científica desta questão implica conhecer a complexidade dos fenômenos que se desenvolvem nesta floresta e compreender os processos definidores à estruturação e manutenção destes ecossistemas no tempo (Rodrigues \& Gandolfi, 1998).

A escolha ou criação de um modelo de restauração é um processo em constante aprimoramento, que é alimentado não só pelos conhecimentos básicos sobre ecologia, demografia, genética, biogeografia, mas também pelas 
informações sobre o ambiente físico e biológico da região onde irá ser implantado (Kageyama \& Gandara, 2000).

Uma forma de incrementar o potencial de auto-recuperação seria através do adensamento e enriquecimento do banco de sementes por semeadura de espécies iniciais em áreas cujo histórico indica a ausência do banco de sementes ou em áreas já ocupadas com espécies inicias por semeadura de espécies tardias, essa é uma estratégia para construir um banco de semente com densidade e diversidade de espécies.

$\mathrm{O}$ adensamento de espécies consiste em introduzir espécies pioneiras no interior de uma capoeira ou de um trecho de floresta degradado (Rodrigues \& Gandolfi, 2000), bem como em áreas sem cobertura florestal. O enriquecimento de espécies consiste em introduzir num remanescente espécies não pioneiras (secundárias tardias ou climácicas) no enriquecimento de florestas secundárias (Kageyama \& Gandara, 2000).

Uma das alternativas ao plantio de mudas de espécies florestais é o uso de semeadura direta, esse modelo visa aumentar as populações de algumas espécies, que em função da degradação, tiveram suas populações muito reduzidas na área (Rodrigues \& Gandolfi, 2000).

Através da semeadura de espécies nativas de diferentes grupos ecológicos, será possível levantar dados sobre a constituição, o adensamento e o enriquecimento do banco de sementes como uma possível prática de recuperação de áreas degradadas, principalmente visando: 1) o primeiro recobrimento do solo; 2) o possível enriquecimento da área (aumento do número de espécies) com a semeadura direta. Vale ressaltar que essa proposta é valida dentro do método de recuperação de áreas que valoriza a restauração dos processos ecológicos e não a restauração de um modelo final idealizado de floresta.

O objetivo geral desse trabalho foi analisar a viabilidade metodológica da constituição artificial de banco de sementes de espécies florestais nativas, como estratégia de recuperação de áreas degradadas. 
Este trabalho teve como objetivos específicos:

$\checkmark$ Estudar espécies potenciais para uso de semeadura direta de espécies nativas em áreas degradadas, quanto à emergência de plântulas e se o número de indivíduos estabelecidos após um ano da semeadura é o suficiente para ocupação florestal de uma área degradada;

$\checkmark$ Avaliar diferentes condições (tratamentos) da semeadura a lanço de espécies florestais nativas para potencializar a emergência de plântulas. 


\section{REVISÃO DE LITERATURA}

\subsection{Bases e conceitos da disciplina recuperação de áreas degradadas}

Uma área degradada pode ser definida como local onde após um distúrbio causado principalmente pelo uso incorreto, comprometeu ou eliminou os seus meios de regeneração natural apresentando assim uma baixa resiliência (Pimm, 1986), ou seja, pode ou não ocorrer seu retorno ao estado original (Kageyama et al., 1989). Já uma área perturbada é aquela que sofreu algum distúrbio, porém manteve seus meios de regeneração biótica (Carpenezzi et al., 1990).

O processo de recomposição florística de um ecossistema natural, perturbado naturalmente ou por ação antrópica, pode ser realizado utilizando-se técnicas de restauração, recuperação ou reabilitação (Herrera et al., 1993). A restauração é caracterizada pela manutenção dos meios de regeneração biótica, podendo recompor naturalmente ao longo do tempo, quando somente mantido em pousio e melhor ainda se receber ajuda do homem. Recuperação é a recomposição de algumas características mais importantes, enquanto reabilitação é a formação de um novo ecossistema com características desejáveis, porém distintas à original (Flores-Aylas, 1999).

De acordo com Engel \& Parrotta (2003), por muito tempo o termo restauração e seu equivalente em inglês "restoration" foi utilizado dentro de seu sentido restrito, expressando o retorno ao estado original do ecossistema. 
idéia da restauração difundia erroneamente o conceito de que os objetivos seriam praticamente impossíveis de se alcançar, já que as condições originais dos ecossistemas dificilmente são conhecidas e os rumos da sucessão secundária nem sempre podem ser previstos. Desta maneira, no Brasil, sempre predominou e predominam ainda hoje o uso dos termos recuperação e reabilitação ao invés de restauração.

Rodrigues \& Gandolfi (2000) salienta que existem muitas divergências no emprego dos termos mais adequados para expressar os objetivos pretendidos num dado programa de recuperação de áreas. Os autores recomendam a adoção da nomenclatura proposta por Aronson et al. (1995) pela clareza dos conceitos envolvidos na definição nomenclatural e pelo fato de estar sendo adotada na maioria das publicações de síntese desta disciplina científica. Nessa definição nomenclatural são introduzidos dois conceitos importantes: o primeiro define que a recuperação de uma dada área depende da trajetória percorrida durante a degradação e de quais foram às conseqüências deste processo no ecossistema em questão; o segundo enfoca que, embora se possa definir um objetivo pretendido com a recuperação, este também só poderá ser alcançado através de uma dada trajetória que se desenvolverá na recuperação da área degradada.

Desta forma, a degradação de um ecossistema ocorreria segundo uma determinada trajetória e caso esta degradação não tenha sido muito profunda, a sua recuperação poderá acontecer passando por um caminho exatamente inverso ao percorrido durante a degradação ou então por uma trajetória alternativa, mas que conduza o ecossistema ao estado inicial. Em níveis mais intensos de degradação, alguns limites poderiam ter sido ultrapassados impedindo o retorno natural do ecossistema à condição inicial, sendo necessário nesse caso, uma forte intervenção antrópica para que sejam superados impedimentos existentes à recuperação natural do ecossistema. Desta forma possibilitar-se-á o retorno da área à condição original ou pré-existente ou a algum estado estável permanente (Rodrigues \& Gandolfi, 2000). 
A restauração como definida por Engel \& Parrotta (2003) não deve ter a pretensão de refazer uma floresta exatamente igual à que existia antes, mas sim colocar no campo uma composição de espécies, de tal forma que forneça condições para que essa nova comunidade tenha maior probabilidade de se desenvolver e se autorenovar, ou que tenha maior probabilidade de ser sustentável.

Assim sendo, a restauração busca a recuperação de parte da biodiversidade local, e a facilitação dos processos biológicos relacionados à manutenção do ecossistema florestal, através do plantio, condução e manejo de espécies florestais nativas (Kageyama et al., 2003).

Para Kageyama \& Gandara (2000), a restauração de ecossistemas degradados, também denominada "revegetação" e "recomposição florestal", deve utilizar os conceitos de diversidade de espécies, interação entre espécies, sucessão ecológica, assim como adaptar as tecnologias já conhecidas da silvicultura tradicional às espécies nativas. A meta da restauração é a de criar um novo ecossistema o mais semelhante possível ao original, de modo a criar condições de biodiversidade renovável, em que as espécies regeneradas artificialmente tenham condições de serem auto-sustentáveis, ou que sua reprodução esteja garantida e a diversidade genética em suas populações possibilite a continuidade de evolução das espécies.

Hobbs \& Harris (2001) ressaltam que os objetivos da restauração devem se concentrar muito mais nas características desejadas do ecossistema no futuro do que pretéritas.

Lamb et al. (1997) citados por Engel \& Parrotta (2003), destacam algumas razões pelo quais torna-se difícil "recriar" as condições originais exatas de ecossistemas florestais tropicais: sua enorme e ainda pouca conhecida riqueza de espécies; a pequena representatividade dos remanescentes florestais em relação à diversidade de habitats original, uma vez que as áreas mais férteis e de topografia mais plana são hoje mal representadas por terem sido submetidas a maior pressão de ocupação agrícola; a falta de conhecimento 
das necessidades de habitat da maioria das espécies e a natureza estocástica da sucessão. Os autores consideram que, mesmo assim, objetivos mais modestos de restauração podem ser definidos, como o restabelecimento de uma comunidade estável, rica em espécies vegetais e animais.

Para Lugo (1992) as dificuldades associadas à restauração dos ecossistemas florestais variam, consideravelmente de sítio para sítio. Estas dificuldades são decorrentes da estrutura inicial e composição de espécies, características do solo, do clima, complexidade e resiliência dos processos básicos do ecossistema (fluxo de energia, ciclos biogeoquímicos, história, persistência e intensidade de distúrbios), que inibem ou retardam os processos de sucessão natural.

Segundo Parrotta (1993), os objetivos primordiais da restauração são: facilitar, acelerar e direcionar os processos sucessionais naturais, aumentar a produtividade biológica, reduzir o processo de erosão do solo, aumentar a fertilidade e o controle biótico sobre os fluxos biogeoquímicos dentro do ecossistema.

Kageyama \& Gandara (2000) apontam que os principais pontos abordados nas estratégias de regeneração e nos modelos empregados são diversidade de espécies, eficiência da regeneração natural, interação plantaanimal e representatividade da população.

\subsubsection{O desenvolvimento de métodos para restauração florestal}

Nos últimos anos houve importantes mudanças metodológicas na área da ecologia de restauração, tais mudanças têm sido baseadas no Paradigma Contemporâneo, o Paradigma do não equilíbrio como denominado por Pickettet al. (1992) - A Natureza em Fluxo. Nesse Paradigma é aceita a teoria de que as mudanças sucessionais da vegetação podem ocorrer seguindo múltiplas trajetórias, não existindo uma convergência nas mudanças do sistema para 
chegar a um "ponto clímax único". A incorporação desses conceitos nos trabalhos de restauração ecológica está proporcionando importantes alterações metodológicas (Nave, 2005).

De acordo com o Paradigma Contemporâneo são necessárias três condições básicas para que ocorram os processos de sucessão em uma área a ser restaurada: a) Disponibilidade de local adequado; b) Disponibilidade de diferentes espécies; c) Disponibilidade de diferentes performances entre as espécies (Pickett et al., 1987; Barbosa, 2004).

A base conceitual mais forte da restauração ecológica tem sido a sucessão natural (Young, 2000). Os modelos de sucessão têm sido usados para desenvolver esquemas de plantio (Kageyama et al., 1992; Rodrigues et al., 1992; Goosem \& Tucker, 1995; Reis, 1999) e para prever se os projetos de restauração atingiram seus objetivos (Parker, 1997; Siqueira, 2002; Sorreano, 2002; Souza, 2002; Bertoncini, 2003; Farah, 2003; Rozza, 2003; Souza \& Batista, 2004). Engel \& Parrotta (2003) lembram que a sucessão é o processo pelo qual os ecossistemas se recuperam de distúrbios e, portanto, compreender como este processo atua em um dado sítio é fundamental. Apenas iniciar o processo de sucessão muitas vezes é o suficiente, mas em casos em que o nível de degradação foi muito intenso, é necessário usar estratégias de longo prazo.

O estudo do processo de sucessão secundária (Budowski, 1965; Deslow, 1980; Gómes-Pompa \& Vásques-Yanes, 1981; Whitmore, 1982; Martinez-Ramos, 1985) tem sido a fonte primordial para o desenvolvimento de métodos de recomposição.

A sucessão secundária é o processo de mudanças que se verifica nos ecossistemas após a destruição parcial da comunidade. Pode ser em uma pequena área de floresta nativa, devido à queda de uma árvore, ou em vários hectares de uma cultura agrícola abandonada. Nesse processo, ocorre uma progressiva mudança na composição florística da floresta, iniciada a partir de espécies pioneiras até espécies climácicas (Kageyama \& Gandara, 2003). 
Segundo Gómez-Pompa (1971), esse mecanismo é responsável pela auto-renovação das florestas tropicais, através da cicatrização de locais perturbados, ou clareiras, que ocorrem a cada momento em diferentes pontos da mata.

As clareiras são formadas pela morte natural ou acidental de uma ou mais árvores, resultando em uma abertura no dossel da floresta. Nesses locais, há uma grande mudança nas condições ambientais, tais como o aumento da quantidade de luz, de temperatura do solo e do ar e da disponibilidade de nutrientes, em um decréscimo da umidade relativa (Bazzaz \& Pickett, 1980).

O fator principal que influência a colonização de clareiras é a luz. Diferentes tamanhos e formas de clareiras produzem situações diversas de microclima, possibilitando que diferentes grupos de espécies se estabeleçam (Kageyama \& Gandara, 2000).

Nas clareiras, ocorre uma reocupação por diferentes grupos ecológicos de espécies adaptadas a regenerar em clareiras de diferentes tamanhos (Whitmore, 1982).

A classificação das espécies, baseada na resposta a essas clareiras, pode ser muito interessante para o entendimento da dinâmica das florestas tropicais e para a elaboração de estratégias de regeneração de áreas desflorestadas.

Os grupos ecológicos sucessionais da floresta tropical têm sido descritos por diversos autores, com diferentes visões e tipos de sucessão, porém com uma certa concordância para os estágios serais mais iniciais ou finais, e algumas diferenças quanto aos grupos intermediários. Os autores divergem também quanto à ocorrência ou não de uma separação brusca entre os grupos, porém há uma certa unanimidade quanto à existência, em si, dos diferentes grupos ecológicos.

A seguir é apresentada uma classificação desses grupos ecológicos citados por Kageyama \& Gandara (2003): 
- Pioneiras: espécies arbóreas e arbustivas que recobrem rapidamente o solo utilizam imediatamente os nutrientes da camada superficial do solo e produzem sombra às espécies dos estágios seguintes da sucessão. As pioneiras típicas, na sucessão secundária têm ciclo de vida curto (5 a 15 anos), reprodução abundante e precoce e as suas sementes ficam dormentes no solo (banco de sementes). As pioneiras antrópicas, na sucessão do próprio nome, normalmente têm ciclo de vida mais longo (10 a 30 anos), podem ou não ter dormência de sementes e normalmente não formam banco de sementes que fecham clareiras grandes na floresta natural. Esse grupo de pioneiras pode ser incluído como sendo as secundárias iniciais de Budowski (1965) ou as pioneiras longevas de Martinez-Ramos (1985).

- Secundárias: espécies arbóreas do dossel ou emergentes na floresta natural, com ciclo de vida longo (100 anos ou mais), cujas sementes normalmente anemocóricas não têm dormência e podem germinar a sombra, mas o banco de plântulas necessita de clareiras pequenas para se desenvolver. Esse grupo geralmente tem muita baixa densidade de indivíduos na mata e é responsável pela alta diversidade de espécies da floresta tropical. As espécies de clareiras pequenas de Deslow (1980), as secundárias tardias de Budowski (1965) e as nômades de Martinez-Ramos (1985) podem ser incluídas neste grupo de secundárias.

- Climácicas: espécies arbóreas de sub-bosque, do subdossel com ciclo de vida médio a longo (40 a 100 anos ou mais), cujas sementes podem germinar a sombra e com banco de plântulas que tem a capacidade de desenvolver também sob o dossel da floresta. As espécies de não clareiras de Deslow (1980) e as tolerantes de Martinez-Ramos (1985) podem ser incluídas no grupo das climácicas.

Para os estudos de recomposição florestal é extremamente importante o uso de classificações quanto aos grupos ecológicos. A partir deste conhecimento é possível escolher mais fácil e de forma precisa às espécies a 
serem utilizadas, incrementando o sucesso no método de recuperação a ser empregada.

\subsubsection{Métodos de recomposição florestal}

Com os avanços na compreensão da floresta tropical, vários modelos de recomposição florestal foram desenvolvidos para implantação de vegetação arbórea nativa no Brasil. Porém, a maior parte das vezes, a recuperação condiciona-se ao plantio de mudas sem se dar conta do potencial de autorecuperação da área ou ao uso de técnicas alternativas (Rodrigues \& Gandolfi, 2000).

Kageyama \& Mendes (1996), Rodrigues \& Gandolfi (1996) e Barbosa \& Barbosa (1998) citam que no processo de recuperação, a diversidade representa um dos aspectos que muitas vezes não é contemplado. Os autores lembram que a alta diversidade de espécies é a principal característica da floresta tropical. A recuperação visa: a recuperação da vegetação original, com o máximo de diversidade de espécies locais, restabelecer o maior número de inter-relações ecológicas de forma a aumentar a variabilidade do sistema. Destaca-se porém que, a alta diversidade de espécies da floresta tropical implica em raridade para a maioria das espécies, com um pequeno número de espécies comuns (Kageyama \& Gandara, 2000).

As métodos usadas para a recomposição florestal podem ser divididas em duas classes: regeneração natural e regeneração artificial.

Regeneração natural: O primeiro medida a ser tomado para a escolha dos modelos de restauração é a observação do potencial de regeneração natural do ambiente degradado (Kageyama \& Gandara, 2000). Neste sistema há necessidade de uma leve ação antrópica, tal como, indução do banco de sementes, preservação de plântulas e árvores remanescentes, adequação do 
sítio para a entrada e desenvolvimento de propágulos alóctones oriundos de remanescentes florestais próximos (Rodrigues \& Gandolfi, 2000).

Regeneração artificial: Em ambientes degradados onde não haja possibilidade de indução da auto-recuperação, será necessário o uso da regeneração artificial. Este sistema altamente antrópico é realizado basicamente por plantios de mudas de espécies arbóreas, tendo também outras opções alternativas como: transporte de serrapilheira alóctone e semeadura direta no sítio a ser recuperado, entre outros. Porém o uso desses métodos alternativos é muito restritivo para a recuperação, devido a carências de informações até ao momento.

O que prevalece nos dias atuais no Brasil é o uso de modelos de implantação florestal a partir do plantio de mudas, dentre estes se pode citar os trabalhos de Kageyama et al. (1990), Rodrigues et al. (1992), Barbosa et al. (1993), Macedo et al. (1993), Botelho et al. (1995) entre outros. Os diferentes modelos usados por estes autores diferem na composição, disposição e espaçamento das espécies florestais nativas dos diferentes estágios sucessionais. Porém, o uso de modelos com plantio de mudas é ainda muito caro tornando-se limitado aos pequenos e médios proprietários.

Deste modo há necessidade e uma extrema urgência de pesquisar e desenvolver métodos alternativos para recomposição florestal.

Martins (2001) cita que o uso da serrapilheira para recuperação de áreas parte do pressuposto de que a serrapilheira contém grande parte do banco de sementes de espécies pioneiras, de nutrientes e de matéria orgânica, desta forma, após a germinação, as plântulas encontrarão condições mais adequadas para o seu estabelecimento, desencadeando o processo sucessional na área com um todo. Espera-se que os melhores resultados sejam obtidos quando a serrapilheira for coletada nas bordas ou em clareiras de florestas secundárias, onde se concentram as espécies pioneiras, que formam banco de sementes e que estarão mais aptas a colonizar a área a ser recuperada. 0 custo envolvido é a coleta e o transporte da serrapilheira até a área a ser 
recuperada. Quando não existem fragmentos de floresta secundária nas proximidades, o custo se eleva, podendo tornar-se inviável.

É importante ressaltar que o uso da serrapilheira é polêmico, pois não se deve degradar uma área para recuperar outra. Sendo assim são necessários mais estudos que investiguem e monitore o impacto gerado na floresta para torná-la uma técnica segura.

Ozório (2000), relata que o transporte de serrapilheira vem sendo muito usado para recuperação em áreas de mineração. O autor discute que numa visão ampla dos resultados de seu experimento, foi observado que a serrapilheira possui um grande potencial para disseminação de propágulos para recuperação de áreas degradadas, porém o sucesso da revegetação dependerá não somente do uso da serrapilheira, mas também de outras técnicas usadas em conjunto.

Dentre os métodos alternativos, a semeadura direta parece ser muito promissora, apresentando bons resultados iniciais quanto ao custo de implantação e o estabelecimento de espécies, expressando assim necessidade e importância de aprimoramento para potencialização de seu uso.

\subsubsection{Regeneração artificial por semeadura direta de espécies florestais}

A revegetação de áreas extensas, utilizando o sistema de regeneração convencional, isto é, com a formação de mudas em viveiros, é onerosa e muitas vezes dificulta a recuperação de áreas degradadas (Franco et al., 1992).

A semeadura direta é um método barato comparado com plantio de mudas porque envolve menos equipamentos e estrutura necessária em viveiros, além de que, grandes áreas podem ser semeadas com menos problemas de organização. Contudo, semente de alta qualidade e alto teor germinativo, muitas vezes não é abundante para permitir sua utilização em semeadura direta (Mattei, 1993). 
As possibilidades de insucesso podem ser reduzidas se houver um controle sobre os agentes destruidores da semente e se as condições de sítio forem favoráveis. O sucesso também depende se a precipitação é suficiente para manter a parte superficial do solo úmida durante o período de germinação e o estágio seguinte. Existem muito mais riscos da sobrevivência ser baixa com o método de semeadura direta do que com o plantio de mudas. No viveiro há um criterioso cuidado dessas plântulas contra inimigos naturais e competições com ervas daninhas, além disso, são pré-selecionadas quanto ao vigor antes de irem para o sítio de plantio. Já as mudas que germinam e crescem no campo não carecem destes cuidados especiais ficando expostas aos numerosos agentes letais, os quais podem ser controlados em viveiros (Smith, 1986).

A semeadura direta é praticada desde antigamente, embora não seja utilizada operacionalmente em muitas regiões. É uma técnica versátil de reflorestamento que pode ser usada na maioria dos sítios e em algumas situações onde a regeneração natural ou plantio não podem ser praticados. É aplicável onde a fonte natural de sementes não é adequada e disponível e onde o acesso, condições de solo torna o plantio difícil, caro ou impossível (Lohrey \& Jones, 1981).

Esta técnica foi gerada como sendo um método rápido e de baixo custo, para reflorestamento de áreas que tinham sido exploradas por corte raso, começando operacionalmente somente no ano 1958. Segundo Cooper et al. (1959) e Campbell (1985), era menos confiável e oferecia menores chances de sucesso do que o plantio de mudas oriundas de viveiros.

A semeadura direta foi desenvolvida para vencer a deficiência de produção de semente em uma área cortada e para recobrir rapidamente grandes áreas com pouco trabalho e baixos custos (Guldin, 1983).

A semeadura direta deve ser considerada como mais uma alternativa para o reflorestamento para fins ecológicos e econômicos não desmerecendo o plantio de mudas e a regeneração natural. 
Experiências comerciais já provaram a rapidez e confiabilidade deste métodos com todas as espécies de Pinus importantes do Sul dos Estados Unidos (Derr \& Mann, 1971; Dougherty, 1990). Como os demais métodos de regeneração, a semeadura direta não é totalmente segura. Dougherty (1990) relata que as principais falhas registradas tem sido antrópicas, tais como: a semeadura em sítios inconvenientes (ou mesmo fora de estação), preparação inadequada do sítio e a utilização de sementes de baixa qualidade.

Sítios onde plantios de mudas tenham falhado devem ser considerados inadequados. Na maior parte das vezes locais que podem ser plantados, também podem ser semeados, todavia, devem ser evitados os sítios baixos e mal drenados, solos profundos e com alto teor de areia os quais secam rapidamente após a chuva e solos sujeitos à erosão onde as sementes são facilmente deslocadas pelo movimento da água (Mann \& Derr, 1964; Derr \& Mann, 1971; Barnett \& Baker, 1991).

A semeadura direta é indicada para proprietários que precisam reflorestar pequenas áreas, sendo recomendado também para grandes áreas destruídas pelo fogo (Barnett \& Baker, 1991). Uma regra básica neste método é a necessidade da semente estar em contato com o solo (Brender, 1973).

A utilização de sementes com elevada taxa de germinação é uma forma de aprimorar este método (Huss, 1956; Dunlap \& Barnett, 1983), somente sementes de boa qualidade devem ser utilizadas. Se viabilidade for abaixo de $85 \%$, talvez o vigor das sementes possa estar declinando rapidamente e as semeaduras de campo podem levar ao insucesso se as condições de campo não forem ideais. Segundo Derr \& Mann (1971), ao invés de se aumentar à quantidade de sementes, quando a viabilidade é mais baixa, é melhor utilizar estas sementes para semeadura em viveiros, onde as condições são mais adequadas. Neste sistema a emergência das plântulas é considerada como resultado da interação entre a semente e o ambiente, que direciona ao desenvolvimento de um método consistente de semeadura direta (Flores-Aylas, 1999). 
Para Smith (1986), o sucesso da semeadura direta também depende de se criar um microssítio com condições tão favoráveis quanto possíveis para uma rápida germinação. As sementes devem ficar em contato com o solo mineral e, se possível, cobertas a uma profundidade compatível para uma germinação bem sucedida. Deve haver umidade permanentemente disponível na camada de solo junto à semente, até a fase em que as raízes tenham penetrado nas camadas mais profundas e possam garantir o suprimento de água.

Em alguns países vários trabalhos têm sido desenvolvidos buscando estratégias para incrementar o método de semeadura direta para repovoamentos de espécies florestais. Este sistema já é bastante difundido e estudado para repovoamentos em florestas boreais nos países da América do Norte (diferentes objetivos de estudos podem ser encontradas em Mann, 1968; Hodgkins, 1966; Waldron, 1974; Dalmacio \& Barangan, 1976; Day \& Ludeke, 1980; Campbell, 1981; Fraser, 1981; Venning, 1985; Putman \& Zasada, 1986; Hazel et al., 1989; Barnett \& Baker, 1991; Bullard, et al., 1992; Fleming \& Mossa, 1994 e 1995, Groot \& Adams, 1994; Fowler, 1995; Haywood \& Grelen, 2000; Cabin et al., 2002; Montalvo et al., 2002;) e Escandinavos (diferentes objetivos de estudos podem ser encontradas em Heth, 1983; Kinnunen, 1982 e 1992; Valtanen \& Engberg, 1987; Bergsten, 1988; Van Damme, 1991; Van Damme \& Bax, 1992; Winsa \& Bergsten, 1994; Winsa, 1995; Muzzi, 1997; Varmola et al., 1998; Wennström, et al., 1999; Wennström, et al., 2001; Winsa \& Sahlén, 2001; Ammer et al., 2002; Brofas \& Karetsos, 2002; Nilson \& Hjältén, 2003; Gratzer \& Rai, 2004).

$\mathrm{Na}$ Austrália a semeadura direta foi introduzida em 1980 visando espécies arbóreas com potencial madeireiro (Clemens, 1980). Só na década de 90 os trabalhos de reflorestamentos com espécies arbustivas e arbóreas para recuperação florestal foram iniciados (diferentes objetivos de estudos, observações e conclusões podem ser encontradas em Sun, et al., 1995; Sun \& Dickinson, 1995 e 1996; Barron et al., 1996; Barron \& Dalton, 1996; Knight et al., 1998). 
No Brasil este método foi introduzido recentemente para reflorestamentos de áreas degradadas (diferentes objetivos de estudos podem ser encontradas em Barbosa et al. 1992a, 1992b; 1996; Flores-Aylas, 1999; Parrotta \& Knowles, 1999; Engel \& Parrotta, 2001; Camargo, et al., 2002; Engel et al., 2002; Mattei \& Rosenthal, 2002; Almeida, 2004) e plantios comerciais (diferentes objetivos de estudos podem ser encontradas em Mattei, 1993, 1995, 1997 e 1998; Serpa, 1999; Brum, 1999; Mattei, et al., 2001; Finger et al., 2003).

Na África (Mandal \& Nielsen, 2004; Owuor et al., 2001) e Ásia (Woods \& Elliott, 2004) esta técnica já demonstra resultados iniciais promissores na recuperação de ecossistemas degradados.

\subsection{Métodos de semeadura direta}

A semeadura direta é um sistema de regeneração alternativo, onde as sementes são espalhadas diretamente no local a ser reflorestado, sem a necessidade da formação de mudas (Toumey \& Korstian, 1967). Os métodos pelos quais pode-se fazer a semeadura são: a lanço em toda área, semeadura em linhas ou em pontos (Barnett \& Baker, 1991). Estes dois últimos parecem minimizar as falhas na semeadura direta, quando previamente selecionados e preparados. Por outro lado o custo é mais alto se comparado com a semeadura a lanço, contudo mais barato que o plantio (Smith, 1986).

Nos Estados Unidos, alguns proprietários têm mudado completamente o modo de produção com espécies arbóreas de plantios comerciais para a semeadura direta. Porém, outros acreditam que o plantio é o melhor método para atingir seus objetivos. Entretanto, a maioria está utilizando ambas as técnicas para obter a máxima vantagem pelo ajuste a cada situação. Derr \& Mann (1971) são convictos de que semeadura direta é tão confiável quanto ao plantio, desde que as operações sejam executadas de acordo com as recomendações. 
Nos países Escandinavos, onde mais de $25 \%$ do total da regeneração artificial é por semeadura direta, as coníferas são restabelecidas utilizando-se este sistema com menor custo que com o emprego de formação de mudas. Este avanço foi dado na década de 70, onde cientistas visando melhorar a germinação e a sobrevivência em semeadura direta, começaram a avaliar o uso de protetores plásticos. O objetivo do protetor era de proporcionar um microssítio mais apropriado para a germinação e crescimento das plântulas (Lähde, 1974).

Os protetores plásticos desde a década de 80 , estão também sendo testados na América do Norte (Putman \& Zasada, 1986). Os autores afirmam ser este mais um artifício positivo para melhorar o desempenho da técnica de semeadura direta.

No Brasil o uso de protetores plásticos foi introduzido na década de 90. As primeiras experiências relatadas em literatura é com uso de protetores em espécies florestais do gênero Pinus (Mattei, 1993, 1995, 1997 e 1998; Brum, et al., 1999; Serpa, 1999; Mattei, et al., 2001). Só recentemente foi testado o uso de protetores em espécies arbóreas nativas (Mattei, 1995; Santos Junior, 2000; Ferreira, 2002; Mattei \& Rosenthal, 2002).

\subsubsection{Implicações do uso da semeadura direta de espécies florestais}

Nos paises de clima temperado, onde a semeadura direta de espécies florestais é uma prática muito antiga, estudos apontam vários fatores que devem ser controlados e monitorados para o sucesso da implantação florestal. Apesar disso, sua aplicabilidade em climas tropicais na maior parte das vezes é inviabilizada, fato atribuído à complexidade nesses ambientes, expressando dessa maneira um grande desafio a ser conquistado pela comunidade científica. 


\subsection{Regiões temperadas}

No Canadá, nas últimas três décadas, este sistema tem se mostrado bastante viável ecológica e economicamente, porque além de promover a conservação do solo e da água, tem reduzido significantemente os custos com fertilizantes (Waldron, 1974; Dalmacio \& Barangan, 1976; Fraser, 1981; Fowler, 1995).

Groot \& Adams (1994) em seus estudos nos Estados Unidos com diferentes tipos de cobertura de solo para avaliar o crescimento de Picea mariana a partir de sementes verificaram, que o estabelecimento de mudas foi melhor quando o solo foi coberto com uma camada de esfagno, proporcionando densidades de 20 a $50 \%$ de mudas estabelecidas para cada 100 sementes semeadas.

Estudos com pinus nos Estados Unidos mostram que a predação de sementes por pássaros e roedores é um fator que interfere significantemente no sucesso da semeadura (Derr \& Mann, 1971; Campbell, 1981). Na tentativa de amenizar a problemática da predação de sementes novas pesquisas têm sido desenvolvidas.

Nolte \& Barnett (2000), estudaram o efeito de um repelente a base de extrato de Capisicum sp. misturado com o fungicida Thiram (THI) em sementes de Pinus palustris L. no controle de predação de sementes por roedores silvestres no sul dos Estados Unidos. Estes autores concluíram que o repelente foi eficiente, diminuindo significantemente a predação das sementes por roedores. Barnett (1998) relata que a oleoreozina, substância que confere as pimentas (Capisicum sp.) sabor picante é ótimo repulsor contra mamíferos predadores de sementes, uma vez que esta causa irritações no trato digestivo, mucosa da boca e olho desses animais, fazendo com que se distanciem dos sítios de semeadura. Por outro lado, é improvável intimidar o consumo das sementes tratadas por pássaros. De acordo com Campbell (1981), o fungicida Thiram é muito usado no controle de predação de sementes contra pássaros e 
mamíferos. Segundo Nolte (1998), este fungicida emite um odor suforoso e quando ingerido impregnado na semente tratada pode induzir o predador ao regurgito.

Para Winsa \& Bergsten (1994), utilizando sementes de Pinus Sylvestris L., e Fleming \& Mossa (1994), utilizando sementes de Picea mariana L., ambos estudos no Canadá, identificaram a preparação do sítio como um fator essencial ao estabelecimento das sementes.

Kinnunen (1982) testando a semeadura direta de Pinus sp. na Finlândia, afirma que para minimizar os problemas com preparação de sítio, predação de sementes é necessário incrementar o número de sementes por área.

Na Suécia (Wennström, et al., 1999; Nilson \& Hjältén, 2002) e Alemanha (Ammer et al., 2002) esforços têm sido intensificados nos últimos anos para o entendimento e aperfeiçoamento da técnica de semeadura.

Nilson \& Hjältén (2002) estudaram o recobrimento das sementes de Pinus sylvestris L. após a semeadura, estes autores concluíram que o recobrimento das sementes imediatamente após semeadura reduz significantemente a predação de sementes e aumentam a emergência das plântulas.

Wennström et al. (1999) testaram o uso de semeadura direta mecanizada de Pinus sylvestris L. em alguns sítios na floresta boreal no norte da Suécia. Os autores indicam esta técnica para repovoamentos em sítios em condições semelhantes por diminuir significantemente o custo do plantio.

Ammer et al. (2002) estudaram na Alemanha a semeadura direta de Fagus sylvatica L. e Picea abies [L] Karst. e relataram que a umidade do solo foi um fator que incrementou significantemente a germinação das sementes e indicam que a capacidade germinativa de sementes é um requerimento básico para êxito desta técnica. 


\subsection{Regiões tropicais}

Diferentemente da América do Norte e Escandinávia, os países tropicais muito recentemente começaram suas pesquisas com semeadura direta de espécies florestais. Devido a grande variação dos ecossistemas tropicais a semeadura direta nestes ambientes é muito mais complexa e requer uma atenção diferenciada.

Um dos grandes obstáculos para o uso de semeadura direta é o fenômeno dormência muito característica das sementes das espécies florestais tropicais. Segundo Toledo \& Marcos Filho (1977), a dormência é de grande significado para as espécies florestais, pois a semente somente germinará quando sua dormência for "quebrada", ou seja, quando houver condições ambientais favoráveis para seu desenvolvimento. Deste modo é imprescindível à eliminação desta barreira para o uso das sementes no sistema de semeadura direta.

Barbosa et al. (1996) citam que a manutenção das condições ideais à germinação e o estabelecimento inicial é de fundamental importância para o sucesso do plantio realizado por semeadura direta. Dentro deste contexto alguns pesquisadores no Brasil (Brum, et al., 1999; Mattei, 1993, 1995, 1997 e 1998; Serpa, 1999; Santos Junior, 2000; Mattei, et al., 2001; Ferreira, 2002; Mattei \& Rosenthal, 2002) utilizaram protetores físicos em pontos de semeadura, que segundo os autores mantêm valores de umidade e temperatura adequados, além de reduzir consideravelmente a mortalidade das plântulas por herbivoria.

A possibilidade de sucesso no estabelecimento de mudas por semeadura direta diminui nas regiões tropicais pela grande variedade dos graus de perturbação da terra. Segundo Sun et al. (1995), para regiões de florestas tropicais úmidas da Austrália, a utilização deste método é recomendado antes que ocorra uma degradação mais intensa, porém torna-se uma prática de risco devido à variação climática. 
Knight et al. (1998) citam que a semeadura direta de espécies arbóreas e arbustivas permite clara opção alternativa de baixo custo em áreas degradadas no Sul da Austrália. Os autores obtiveram sucesso em experimento de campo estudando espécies endêmicas (acácia e eucalipto) na Austrália, no entanto os mesmos advertem que é recomendável utilizar outras espécies pertencentes a gêneros diferentes, com o objetivo de maximizar o sucesso deste sistema de regeneração.

Em experimentos com sementes de Alphitonia petriei (família Rhamnaceae) em casa de vegetação e em campo, Sun et al. (1995) verificaram que a competição com gramíneas e a infertilidade do solo foram os fatores que mais afetaram a sobrevivência e crescimento das mudas no campo. Estes autores afirmam que solos inférteis e compactados são detrimentais à sobrevivência e crescimento das mudas. Lembram que plantas daninhas possuem uma agressividade característica que as torna excepcionais competidoras, já que, em poucos meses colonizam uma determinada área, não permitindo assim o desenvolvimento de espécies arbóreas, principalmente as de crescimento lento.

Flores-Aylas (1999) estudando no Brasil a semeadura de espécies arbóreas nativas em casa de vegetação, ressalta que um simples aumento na densidade de sementes por área, não é o bastante para garantir o sucesso da semeadura, e sim aliar isto a uma prévia preparação do sitio de plantio. Segundo Santos Junior (2000), um preparo do solo, anterior à semeadura, reduz as barreiras físicas a serem encontradas pela plântula, aumenta a absorção de água pelo solo e torna disponíveis nutrientes situados nas camadas inferiores do solo, entre outros fatores.

Owuor et al. (2001), em seus estudos de semeadura direta com Sesbania sesban e Mandal \& Nielsen (2002) com Calliandra calothyrsus no Quênia verificaram que a profundidade da semente no solo, disposição de nutrientes e água são essenciais para o sucesso da semeadura. 
Mattei (1995) no Brasil e Stanton (1975) na Costa Rica, trabalhando com semeadura de Pinus taeda L., relatam que a pressão da herbivoria é outro aspecto que muito influencia a regeneração em florestas tropicais.

Hau (1999), utilizando semeadura direta no Sul da China relata problemas enfrentados com a predação de sementes causada por ratos. Por outro lado, Woods \& Elliott (2004), em seus estudos com semeadura direta no norte da Tailândia em áreas de agricultura abandonada verificaram que as formigas ao invés dos roedores foram os maiores predadores de sementes e que para amenizar este problema é necessário incorporar as sementes ao solo, protegendo-as contra predação por formigas, pássaros e mamíferos e da luz solar direta. Esses cuidados incrementaram significantemente o número de sementes germinadas.

Clemens (1980) estudando semeadura de espécies arbóreas na Austrália sugere o uso de mulch para manter a umidade nas sementes, enquanto Sun \& Dickinson (1995) recomendam enterrar as sementes para mantê-las úmidas no solo e seguras contra o ataque de formigas. Hau (1999) mostrou em seu experimento com semeadura direta na China que uma média camada de solo recobrindo as sementes não foi o suficiente para reduzir o número de sementes predadas.

Nas regiões tropicais onde as espécies arbóreas pioneiras podem ser favorecidas em áreas abertas, as gramíneas e herbáceas invasoras tornam-se uma importante barreira para o seu desenvolvimento inicial, devido à competição (Sun \& Dickson, 1996; Toledo, et. al., 2001) e alelopatia (Souza, et. al., 2003).

As plantas daninhas são consideradas um dos principais fatores que interferem no desenvolvimento inicial das espécies recém implantadas. Pelo método de semeadura direta este fator parece ser ainda mais acentuado, pois as plantas daninhas podem suprimir as espécies desde a germinação das sementes até a fase de estabelecimento das mudas. Desta forma o sucesso da revegetação pode ser seriamente comprometido (Ferreira, 2002). 
A presença de plantas daninhas em áreas de reflorestamento é consideravelmente problemática, uma vez que estas competem por nutrientes, água, luz e $\mathrm{CO}_{2}$, com as mudas recém germinadas ou plantadas. Devido a estes fatores é extremamente necessário realizar um monitoramento periódico para reduzir sua infestação, fato que aumenta consideravelmente o custo da implantação (Davide \& Botelho, 1999).

Do ponto de vista ecológico, a presença de plantas daninhas em algumas áreas, pode ser desejável pelo fato de promover uma cobertura do solo, reduzindo a erosão, melhorando a estrutura física e incorporando a matéria orgânica (Davide et al., 2000).

Em reflorestamentos de espécies comerciais (pinus e eucalipto) com plantio de mudas, o uso de herbicidas pós e pré-emergentes surgiram na década de 80 no Brasil (Pascoal \& Nakano, 1988; Ribeiro, 1988; Rodrigues et al., 1988; Thomaz et al., 1988). O objetivo comum era de reduzir a infestação de plantas daninhas na fase inicial de implantação e assim acelerar o estabelecimento das mudas. Os resultados mostraram-se satisfatório sendo um fator acrescido a ser considerado para aumentar o rendimento dos povoamentos e reduzir o custo de implantação.

Só recentemente foi testado no Brasil o uso de herbicidas pré e pósemergentes no desenvolvimento inicial de mudas nativas estabelecidas por semeadura direta (Ferreira, 2002). O autor testou em seus experimentos o uso de 4 tipos de herbicidas pré-emergentes (imazapyr, atrazina, acetochlor, oxyfluorfen) no controle de ervas daninhas na preparação do sítio de plantio antes da semeadura e o efeito destes no desenvolvimento inicial de 4 espécies florestais nativas pioneiras: Senna multijuga, Senna macranthera, Solanum granuloso-leprosum e Trema micrantha. Dentro os herbicidas testados, o acetochlor apresentou resultados satisfatórios, tanto na emergência de plântulas como na sobrevivência de mudas das espécies florestais nativas testadas. Com a exceção da T. micrantha, as demais espécies mostraram-se susceptíveis a ação do imazapyr na sobrevivência de mudas. A atrazina e o oxyfluorfen 
mostraram-se passíveis de utilização, mas é necessária uma criteriosa avaliação quanto a definição das espécies. O autor ressalta que nenhum dos herbicidas apresentou resultado superior ao tratamento controle, tanto na emergência ou na sobrevivência das mudas e que houve eficiência no controle de plantas daninhas, visto que foi verificada a presença destas neste tratamento.

Por outro lado, é notável que a aplicação inadequada de herbicidas em algumas situações pode promover contaminações irreversíveis no ecossistema (Pitelli \& Karam, 1988). Rodrigues \& Almeida (1998) lembram que os herbicidas podem provocar intoxicações em aves, peixes e abelhas.

Sun \& Dickson (1996) estudaram em casa de vegetação e campo em Queensland na Austrália, o efeito competitivo de Brachiaria decumbens no crescimento inicial de uma espécie pioneira arbórea nativa a Alphitonia petriei, estabelecida por semeadura direta. Em ambos os experimentos (casa de vegetação e campo), a $B$. decumbens limitou o crescimento de $A$. petriei, competindo inicialmente por luz, devido ao rápido crescimento desta gramínea nas primeiras semanas após a germinação. Os autores sugerem o controle de B. decumbens neste período por ser a fase crítica competitiva desta espécie, caso contrário, levará ao insucesso da semeadura de $A$. petriei.

Toledo et al. (2001), no Brasil, estudaram em campo o efeito da densidade de plantas de Brachiaria decumbens no crescimento inicial de Eucalyptus grandis. Os autores verificaram que $B$. decumbens na densidade a partir de 4 plantas $\mathrm{m}^{-1}$ interferiu negativamente sobre o crescimento inicial de $E$. grandis o suficiente para reduzir a biomassa seca do caule $(55,22 \%)$, dos ramos $(77,29 \%)$ e das folhas $(55,30 \%)$, bem como a área foliar $(63,26 \%)$, o número de folhas $(70,56 \%)$ e o diâmetro de caule $(27,78 \%)$. Por outro lado, a altura de $E$. grandis mostrou-se menos sensível $(18,47 \%)$ à interferência de $B$. decumbens.

O trabalho de Souza et al. (2003), evidencia um efeito alelopático de Brachiaria decumbens no desenvolvimento inicial de Eucalyptus grandis. Os autores estudaram a matéria seca incorporada ao solo de 18 espécies de plantas daninhas e $B$. decumbens foi à espécie que demonstrou uma acentuada 
capacidade de reduzir o crescimento de E. grandis em todas as variáveis analisadas (altura, teor de clorofila, área foliar, matéria seca de folhas, caule e raiz). Este fato confirma que a presença de substâncias aleloquimicas no sítio de plantio prejudica o desenvolvimento das espécies florestais em reflorestamentos.

\subsubsection{Semeadura direta de espécies florestais nativas no Brasil}

No Brasil estudos com sistema de semeadura direta de espécies florestais nativas visando à recuperação de áreas degradadas são relatados em literatura somente na forma de experiências como as de Mattei \& Rosenthal (2002), no estado do Rio Grande do Sul; Pompéia et al. (1989), Barbosa et al. (1992a, 1992b e 1996), Engel \& Parrotta (2001) e Engel et al. (2002), em São Paulo; Flores-Aylas (1999), Santos Junior (2000), Ferreira (2002) e Almeida (2004) em Minas Gerais; Camargo et al. (2002) e Parrotta \& Knowles (1999) na Amazônia. Estes autores afirmam ser esta uma prática viável ecologicamente e economicamente, que deve ser incentivada, mas que necessita de estudos complementares que auxiliem no seu sucesso.

Pompéia et al. (1989) é relatado em literatura como o primeiro trabalho no Brasil testando o uso de semeadura de espécies nativas. Os autores testaram na região de Cubatão-SP a semeadura de 39 espécies diferentes pertencentes aos estratos herbáceo, arbustivo e arbóreo definidas como resistentes ou tolerantes à poluição atmosférica. Neste trabalho as espécies foram pelotizidas com gel hidrofílico visando otimizar a proteção, germinação, seu acesso e fixação ao solo uma vez que a semeadura deu-se por via aérea. $A$ semeadura aérea foi realizada por helicópteros e aviões agrícolas resultando no lançamento de 750 milhões de sementes em $15 \mathrm{~km}^{2}$ de trechos degradados na Serra do Mar. De acordo com o primeiro monitoramento realizado em maio de 1989, onde se determinou a densidade de pelotas por metro quadrado e sua 
germinação em laboratório, os autores afirmam que obtiveram uma média de 400 a 600 unidades $/ \mathrm{m}^{2}$, para a semeadura por helicóptero, e de 100 a 200 unidades no plantio por avião agrícola. Quanto à germinação da pelotas recolhidas na região do plantio, obtiveram em laboratório um índice médio de germinação de $80 \%$ sendo considerado satisfatório de acordo com os autores.

Barbosa et al. (1992a) investigaram a viabilidade de enriquecimento de uma área degradada de mata ciliar, testando a semeadura direta de quatro espécies florestais (Aspidosperma olivaceum Muell. Arg., Cariniana estrellensis (Raddi) O. Kuntze, Copaifera langsdorfii Desf. e Hymenaea courbaril L.) comuns da mata ciliar utilizando o método de semeadura em covas. Neste experimento foi estudado o comportamento destas espécies em dois tipos de ambientes: i) Pleno sol e ii) Sub-bosque. Os autores discutem que o fator luz teve grande interferência quanto à porcentagem de emergência das plântulas no subbosque, quando comparadas com os tratamentos em pleno sol evidenciando que as espécies estudadas pertencem ao grupo de espécies secundárias tardias e climácicas dos estágios de sucessão natural. Concluem que a recuperação através do enriquecimento da floresta por sementes é um processo viável, caracterizando-a como mais uma alternativa para ser considerada nos modelos de recuperação de áreas degradadas. Sugerem que outras espécies sejam investigadas considerando a flora específica de cada região a ser recuperada.

Barbosa et al. (1992b) estudaram o estabelecimento de indivíduos a partir de sementes de quatro espécies florestais (Aspidosperma olivaceum Muell. Arg., Cariniana estrellensis (Raddi) O. Kuntze, Copaifera langsdorfii Desf. e Sebastiania serrata (Baill) Muell. Arg.) usando o método de semeadura em covas citada por Barbosa et al. (1992a). Os autores relatam que inicialmente houve competição entre as plântulas, por condições nutricionais, principalmente pelo ambiente e que as dificuldades no estabelecimento inicial pode estar atribuído a vários fatores, entre eles o vigor das sementes. Tal fato foi comprovado com as espécies $C$. estrellensis e C. langsdorfii que apresentaram 
boa germinação nas avaliações iniciais tendo uma considerável taxa de mortalidade nas avaliações seguintes, evidenciando que a utilização de sementes de máxima qualidade é fundamental na semeadura direta. Concluem que o fator competição foi positivo, porque contribuiu para o estabelecimento de indivíduos mais vigorosos e que a semeadura em covas mostrou-se viável. Sugerem que estudos sobre tecnologia e maturação de sementes devem ser incrementados para espécies nativas para assim implementar os trabalhos de recuperação de áreas degradadas com diferentes graus de perturbação.

Barbosa et al. (1996) investigaram a recuperação de trechos degradados em uma área ciliar utilizando semeadura direta em covas (Barbosa et al. 1992a) de Inga uruguensis Hook. et Arn. considerando diferentes condições de umidade do solo (de acordo com a distância do rio) e luminosidade (a pleno sol e sub-bosque). Os resultados obtidos pelos autores mostram que $I$. uruguensis entre os tratamentos estudados, apresenta melhor desenvolvimento em condições de pleno sol e em distância próximas do rio (4$6 \mathrm{~m})$. Os autores concluem que $I$. uruguensis é uma espécie de grande potencial para ser usada em reflorestamentos ciliares por semeadura direta e que a umidade do solo aliada à condição de pleno sol promovem o melhor estabelecimento desta espécie.

Flores-Aylas (1999) estudou o desenvolvimento inicial de seis espécies florestais nativas (Senna macranthera Collad. Irwin et Barn., Guazuma ulmifolia Lam., Senna multijuga Rich. Irwin et Barn., Solanum granuloso-leprosum Dunal, Schinus terebenthifolius Raddi e Trema micrantha (L.) Blume) sob efeito de micorrização e estimulante desta estabelecidas por semeadura direta. 0 experimento foi conduzido em casa de vegetação com tratamentos de inoculação (Glomus etunicatum), Mycoform (estimulante) e fósforo (0,002; 0,02 e $0,2 \mathrm{mg} \mathrm{L}^{-1}$ de $\mathrm{P}$ disponível). De acordo com o autor as espécies responderam à inoculação em baixa fertilidade $\left(0,002\right.$ e $\left.0,02 \mathrm{mg} \mathrm{L}^{-1}\right)$ principalmente para produção de massa seca e área foliar total. O autor relata que S. granulosoleprosum não sobreviveu em solo com $0,002 \mathrm{mg} \mathrm{L}^{-1}$ de $\mathrm{P}$ e foi dominante em 
$0,02 \mathrm{mg} \mathrm{L}^{-1}$. S. macranthera foi dominante em solo com 0,002 $\mathrm{mg} \mathrm{L}^{-1}$. Com a adição de estimulantes somente $S$. macranthera respondeu no crescimento vegetativo. O autor conclui que o crescimento das espécies foi favorecido pela elevação de $P$ e que a inoculação com $G$. etunicatum favoreceu o crescimento e o equilíbrio entre as espécies na semeadura direta e ainda a disponibilidade de $\mathrm{P}$ no solo favoreceu a dominância de certas espécies, principalmente $S$. granuloso-leprosum.

Parrotta \& Knowles (1999) estudaram áreas de mineração recuperadas em quatro diferentes modelos de plantios de espécies florestais, entre eles a semeadura direta. Os autores relatam que as técnicas de plantio foram utilizadas na década de 80 visando à recuperação de áreas mineradas para exploração de bauxita na Amazônia e que a semeadura direta foi realizada com 48 espécies nativas do início da sucessão ecológica. Entre 1995 e 1997 os autores avaliaram a estrutura e a composição florística desses reflorestamentos comparados com uma floresta primária vizinha. Os autores constataram que no tratamento com semeadura direta havia registrado 117 espécies arbóreas pertencentes a 37 famílias e na floresta primária 157 espécies arbóreas pertencentes a 39 famílias. Das 117 espécies pertencente ao tratamento com semeadura direta, somente 42 foram plantadas. A partir destes resultados os autores relembram que a presença de remanescentes próximos e da avifauna, é extremante importante para auxiliar o restabelecimento dos processos ecológicos em áreas degradadas.

Santos Junior (2000) estudou a semeadura direta de cinco espécies florestais nativas (Cedrella fissilis Vell., Copaifera langsdorfii Desf., Enterolobium contortisiliquum Vell., Piptadenia gonoacantha (Mart.) Macbr. e Tabebuia serratifolia (Vahl) Nich.) utilizando protetores físicos para sementes. O experimento foi conduzido em duas áreas: uma na condição de luz direta incidente (viveiro florestal) e outra em um sub-bosque de Trema micrantha. $\mathrm{O}$ autor discute que o protetor físico favoreceu a germinação, tanto no que se refere à quantidade quanto a velocidade de germinação das sementes das cinco 
espécies estudadas. O protetor auxiliou também na sobrevivência das plantas por promover maiores temperaturas em seu interior quando comparado com o meio externo. No que se refere ao desenvolvimento inicial das espécies, o autor comenta que o uso do protetor germinativo influencia de forma positiva no desenvolvimento inicial das espécies. Conclui que para as espécies estudadas o método de semeadura direta mostrou se viável.

Engel \& Parrotta (2001) estudaram o desenvolvimento de cinco espécies florestais nativas (Chorisia speciosa St. Hil, Croton floribundus Spreng, Enterolobium contortisiliquum (Vell.), Mimosa scabrella Benth., Schizolobium parahyba (Vell) Blake utilizando o método de semeadura direta em linhas em 3 diferentes sítios de plantios. Das espécies estudadas somente duas delas ( $E$. contortisiliquum e S. parahyba) apresentaram boa germinação (respectivamente 88-100\%) e sobrevivência (respectivamente 1050-1790 indivíduos por hectare). Os autores avaliaram o custo operacional para estabelecimento e manutenção do plantio durante 2 anos nos três sítios considerando: materiais, maquinários, sementes, preparação do sítio (roçadas, aração da terra e aplicação de herbicidas), plantio (semeadura das sementes) e manutenção (capina, aplicação de herbicidas e formicidas). Nos sítios 2 e 3 tiveram gastos totais de US\$747/ha (valor cotado do dólar no período: $\mathrm{R} \$ 1,70$ ) enquanto que o sítio 1 foi gasto US\$ 912/ha. Os autores reportam que os custos com o estabelecimento variaram entre 63 a 68\% dos custos totais e que o sítio 1 teve maior custo em relação aos sítios 2 e 3, devido a necessidade da supressão física de capim napier ( $P$. purpureum) por roçada mecânica antes da aplicação de herbicida e ainda custos adicionais na semeadura manual. Relatam ainda que estes custos comparados com o plantio a partir de mudas nativas produzidas em viveiros seriam bem mais caros ficando em torno de US\$1200 a 2500/ha e que o estabelecimento e manutenção em plantações comerciais de Eucaliptus ficam em torno de US\$ 700/ha. Os autores relatam também que apesar do baixo desempenho de $C$. speciosa, C. floribundus e M. scabrella em condições de campo o método de semeadura mostrou-se viável e que 2 anos após a semeadura, os sítios de 
plantios demonstravam já elevada regeneração natural providas de fontes alóctones.

Camargo et al. (2002) testaram a semeadura direta de onze espécies florestais nativas (Ochroma pyramidale Cav. ex. Lam., Jacaranda copaia D. Don. Cochlospermum orinoccense (H.B.K.) Steud., Buchenavia grandis Ducke, Tripalaris surinamensis Cham., Parkia pendula Benth. ex. Walp, Cariniana micrantha Ducke, Diniza excelsa Ducke, Simarouba amara Aubl. Caryocar villosum Aubl., Parkia multijuga Benth.) como técnica de reabilitação em sítios com diferentes graus de perturbação considerando: solo nu, pastagem, floresta secundária e floresta madura. Os autores relatam que após um ano, 33\% das sementes semeadas de somente oito espécies (B. Grandis, C. villosum, $C$. orinoccense, S. amara, C. micrantha e D. excelsa) desenvolveram em solo nu. $\mathrm{Na}$ pastagem foi estabelecido 23\%, na floresta secundária 15\% e na floresta madura $12 \%$ de somente quatro espécies semeadas (B. Grandis, C. villosum, $C$. orinoccense, S. amara). Os autores discutem uma relação positiva entre o tamanho da semente e a sobrevivência das plântulas e que a espécie que melhor se destacou com mais de $45 \%$ de emergência em todos os sítios foi $C$. villosum (espécie não pioneira). Diferentemente de todos os outros sítios estudados, o sítio com solo nu apresentou baixas taxas de predação e nele não houve competição interespecífica pelo fato de não estar recoberto por nenhuma vegetação. Os autores recomendam plantio de mudas pioneiras para ocupação da área a ser restaurada em conjunto com semeadura de espécies não pioneiras. Enfatizam que quanto maior o tamanho da semente mais chances de estabelecimento da plântula. Concluem que das espécies estudadas C. villosum e $P$. multijuga são recomendadas para reabilitação com semeadura direta em áreas degradadas na Amazônia central e que o sucesso da semeadura depende em parte da fauna presente na área a ser reabilitada.

Engel et al. (2002) testaram o uso de semeadura direta mecanizada para implantação florestal de onze espécies florestais nativas em solos degradados, visando à recuperação da fertilidade do solo e a restauração da 
floresta. As espécies testadas foram: Ormosia arborea (Vell.) Harms, Chorisia speciosa St. Hil, Anadenanthera macrocarpa (Benth.) Brenan, Enterolobium contortisiliquum (Vell.), Schinus terebinthifolius Raddi, Peltophorum dubium (Spreng.) Taub., Copaifera langsdorfii Desf., Aegyphylla sellowiana Cham, Piptadenia gonoacantha (Mart.) J.F.Macbr, Hymenaea courbaril L. e Schizolobium parahyba (Vell) Blake, destas somente sete germinaram em campo (C. speciosa, E. contortisiliquum, S. terebinthifolius, $P$. dubium, $P$. gonoacantha, $H$. courbaril e S. parahyba). O plantio foi realizado por plantadeira convencional de lavoura regulada para três linhas de plantio espaçadas de um metro, sendo a central correspondente à mistura de espécies nativas e as duas laterais sementes de adubo verde (Canavalia ensiformis e Cajanus cajan). Os autores relatam que os custos de estabelecimento e manutenção do plantio ficaram entre US\$297.38 e US\$ 440.16 (valor cotado do dólar no período: R\$ 2,40 ), o que afirmam serem bastante baixos. Concluem que o sistema mostrouse viável como método de baixo custo para solos pobres e degradados, principalmente em áreas onde existam fragmentos florestais nativos que possam funcionar como fonte de propágulos para a colonização de outras espécies.

Ferreira (2002) estudou a semeadura direta de cinco espécies florestais nativas (Cecropia pachystachya Trec., Senna multijuga (Rich.) Irwin et Barn., Senna macranthera (Collad) Irwin et Barn., Solanum granuloso-leprosum Dunal e Trema micrantha (L.) Blume) visando à implantação de matas ciliares. Os objetivos deste trabalho foram: a) avaliar o efeito da superação da dormência e do efeito de um protetor físico na emergência desenvolvimento inicial das mudas; b) avaliar a viabilidade de sementes do banco introduzido, em condições naturais; c) avaliar o comportamento das espécies durante as fases de emergência de plântulas e crescimento inicial de mudas em casa de vegetação em função da aplicação de herbicidas pré-emergentes. No experimento "a" o autor relata que os tratamentos utilizados para superar a dormência das espécies estudadas foram eficientes em laboratório, com exceção somente de S. macranthera. Já em condições de campo, os tratamentos utilizados 
beneficiaram somente S. multijuga e S. macranthera. A presença do protetor físico não beneficiou nenhuma espécie, em relação à emergência de plântulas e a sobrevivência das mudas, mas promoveu maior altura e diâmetro do colo em S. multijuga e maior altura em S. macranthera, aos 3 meses de idade. No experimento "b" o autor verificou através do teste de tetrazólio $\left(0,075 \%\right.$ a $\left.30^{\circ} \mathrm{C}\right)$ as sementes de duas espécies (S. multijuga e S. macranthera) semeadas no experimento "a", aos 0, 6, 12 e 18 meses após a semeadura no campo. As sementes destas espécies apresentavam-se viáveis caracterizando 0 comportamento típico de espécies que formam banco de sementes persistente. No experimento "c" o autor verificou a influência dos herbicidas imazapyr, atrazina, acetochlor e oxyfluorfen sobre a emergência e desenvolvimento inicial das espécies estudadas. Verificou-se que o acetochlor apresentou resultados satisfatórios, tanto na emergência de plântulas como na sobrevivência de mudas das espécies S. multijuga, S. macranthera, S. granuloso-leprosum e $T$. micrantha. O autor reporta que com exceção da T. micrantha, as demais espécies mostraram-se altamente susceptíveis à ação do imazapyr e que a atrazina e oxyfluorfen mostraram-se passíveis de utilização, mas é necessário que a escolha das espécies sejam criteriosamente avaliadas. Concluindo que pelos resultados obtidos é viável o uso da semeadura direta para implantação de florestas nativas.

Mattei \& Rosenthal (2002) avaliaram o comportamento de Peltophorium dubium (Spreng) Taub., estabelecida por semeadura direta em pontos protegidos por dois tipos de protetores físicos (copo de plástico e de papel sem fundo e laminado de madeira) em uma área de capoeira originada após o abandono do local utilizado com cultivos agrícolas sucessivos. Em cada ponto foi semeado 3 sementes de $P$. dubium. Os autores discutem que o protetor físico melhorou significantemente o estabelecimento das plantas em relação à testemunha em todas as variáveis avaliadas (emergência, sobrevivência, número de pontos com plantas, densidade a 1 ano e altura das plantas aos 18 meses) pelo fato de que, aos nove meses, $80 \%$ dos pontos semeados usando 
qualquer um dos protetores físicos apresentavam plantas estabelecidas. Neste trabalho os autores lembram que o protetor físico demonstra ser eficiente perante as adversidades ambientais, porem pouco sobre as biológicas. Os autores concluem que a semeadura direta de $P$. dubium é indicada para enriquecimento de capoeiras; que os protetores físicos em pontos de semeadura expressam efeitos benéficos sobre a emergência, sobrevivência e densidade inicial; e que o laminado de madeira por ser biodegradável e de custo reduzido, é o protetor recomendado.

Almeida (2004) estudou a semeadura de doze espécies florestais nativas (Cedrella fissilis Vell., Copaifera langsdorfii Desf., Enterolobium constortisiliquum Vell., Guazuma ulmifolia Lam., Lithraea molleoides Rich., Piptadenia gonoacantha (Mart.) Macbr., Senna macranthera (Collad) Irwin et Barn., Senna multijuga (Rich.) Irwin et Barn., Sesbania virgata L., Solanum granuloso-leprosum Dunal, Tabebuia serratifolia (Vahl) Nich. e Trema micrantha (L.) Blume.) para implantação de mata ciliar. Neste trabalho foram usadas sementes peletizadas em plantio direto mecanizado em três diferentes espaçamentos $(0,4 \mathrm{~m}, 0,7 \mathrm{~m}$ e $1,0 \mathrm{~m})$, manejos realizados por capina, uso de herbicida pré-emergente e testemunha. A autora relata, que com exceção de $L$. molleoides, as demais espécies apresentaram emergência de plântulas no campo e que, as maiores populações de plantas/ha, os maiores crescimentos foram obtidas no espaçamento $0,4 \mathrm{~m}$ e nas parcelas manejadas por capina. $\mathrm{O}$ herbicida pré-emergente de acordo com a autora, não foi eficiente no controle total de braquiária agindo apenas na minimização da ocorrência de plantas daninhas. S virgata, E. contortisiliquum e $C$ langsdorfii, foram as espécies que apresentaram as maiores emergências de plântulas no campo. A mortalidade média foi de $11,77 \%$ quando manejada por capina, 25,69\% ao utilizar herbicida pré-emergente e $24,67 \%$ na testemunha. Neste experimento, segundo a autora, a semeadura mecanizada com sementes peletizadas mostrou-se eficiente para implantação de mata ciliar. 
Diante dos diferentes trabalhos apresentados é relevante destacar a importância do estudo e incentivar o aprimoramento da técnica de semeadura direta no Brasil visto que os resultados iniciais já provaram a viabilidade deste método.

\subsubsection{Semeadura direta versus plantio de mudas}

Experiências usando o plantio de mudas já demonstram bons resultados no Brasil. Alguns modelos propostos por pesquisadores podem ser adotados em várias situações semelhantes para revegetar áreas antropizadas (Kageyama \& Castro, 1989; Kageyama et al., 1989; Salvador, 1989; Kageyama et al., 1990; Durigan \& Nogueira, 1990; Rodrigues et al., 1992; Barbosa et al., 1993; Macedo et al., 1993; Davide, 1994; Davide et al., 1994; Kageyama et al., 1994; Faria et al., 1994; Botelho et al., 1995; Faria, 1996; Gandolfi \& Rodrigues, 1996; Rodrigues \& Gandolfi, 1996 e 1998; Santarelli, 1996 Barbosa, 2000; Kageyama \& Gandara, 2000).

Quanto às vantagens financeiras a semeadura direta em relação ao plantio de mudas pode ter um custo muito reduzido em função de baixos gastos com mão-de-obra e maquinários e a isenção da fase de viveiro que representa boa parte dos custos na implantação. De acordo com Faria (1999) a média de custo de uma muda produzida em tubete varia de $R \$ 0,18$ a $R \$ 0,23$, considerando-se tanto espécies pioneiras quanto não pioneiras. Quando produzidas em sacos plásticos, o custo médio pode variar de $R \$ 0,50$ a $R \$ 1,00$.

Kageyama \& Gandara (2000) citam que em 1988, o tempo de implantação de florestas com plantio de mudas era em torno de 5 a 7 anos, com custo médio de US\$4.000/ha, enquanto nos dias atuais o tempo pode ser reduzido para 2 anos, com custo médio de US\$1.500/ha. 
É evidente que há necessidade de incentivos a novas pesquisas para gerar técnicas alternativas a fim de tornar o processo de revegetação mais acessível aos proprietários de médio e pequeno porte.

Neste sentido Engel \& Parrota (2001), em seus estudos com semeadura direta, relatam que os custos de implantação de floresta nativa a partir de plantio de mudas produzidas em viveiros ficariam entre US\$1200 e US\$2500/ha enquanto que por semeadura direta este custo seria reduzido para US\$ 912/ha até US\$ 745. Engel et al. (2002) acreditam que este valor pode ser ainda mais barato, reduzido para US\$ 297 a US\$ 440/ha.

Quanto às vantagens biológicas as plântulas providas da semeadura direta quando comparada com mudas produzidas em viveiros apresentam menor risco de deformação do sistema radicular e menos problemas no estabelecimento das plântulas (Long, 1978; Hultén, 1982; Mattei, 1993). Porém seu uso em grande escala é ainda limitado, devido à inconsistência dos resultados quanto à emergência, sobrevivência e crescimento das plantas (Valtanen \& Engberg, 1987).

Para Smith (1986) uma das vantagens da semeadura sobre o plantio é que as raízes das plantas crescem em arranjo natural e normal. Já plântulas providas de viveiros podem apresentar anormalidades em suas raízes que é raramente observada por estarem ocultas. Esses problemas afetam significantemente o desenvolvimento da muda, após a primeira fase de crescimento que na maioria das vezes são difíceis de serem solucionados.

O método de semeadura direta em comparação com o plantio apresenta vantagens e desvantagens, dependendo das situações em que a mesma será executada. Segundo Heth (1983), as vantagens excedem marcadamente as desvantagens, sendo as principais: - é dispensada a fase de viveiro necessária para produção de mudas; é evitada a distorção do sistema radicial da muda; é evitado o choque do plantio; as raízes originadas diretamente no ponto de semeadura desenvolvem-se melhor do que aquelas plantadas; a semeadura direta é mais adequada à mecanização. Por outro lado, 
às mudas nos dois primeiros anos pós-germinação requerem mais cuidados e tratos culturais adicionais, bem como maior supervisão durante todas as fases. 


\section{MATERIAS E MÉTODOS}

\section{1 Área de implantação do projeto}

O trabalho foi realizado na Fazenda Paineiras, propriedade particular pertencente à Cia. Açucareira Vale do Rosário. A área foi escolhida por já estar sendo desenvolvido nas propriedades agrícolas dessa empresa, um Programa de Adequação Ambiental, através de um convênio coordenado pelo Laboratório de Ecologia e Restauração Florestal (LERF) da ESALQ/USP (Rodrigues et al., 2002).

A área experimental localiza-se na Fazenda Paineiras, noroeste do Estado de São Paulo no município de Morro Agudo, nas coordenadas geográficas: $20^{\circ} 42^{\prime} 38^{\prime \prime} S$ e $47^{\circ} 59^{\prime} 17$ 'W, com altitude aproximada de 590m.

Nessa região, apesar de ser uma área muito ocupada pela agricultura, principalmente a cana-de-açúcar, ainda restam alguns remanescentes naturais, localizados principalmente nas Áreas de Preservação Permanente em diferentes graus de perturbações. Os formações florestais da região foram classificadas em quatro fisionomias (Rodrigues et al., 2002):

$\checkmark$ Cerradão;

$\checkmark$ Floresta Estacional Decidual;

$\checkmark$ Floresta Ribeirinha;

$\checkmark$ Floresta Paludosa.

O clima da região é classificado como tropical chuvoso, Cwa, de acordo com a classificação climática de Köppen (1948). As chuvas ocorrem no período 
de outubro a março, a temperatura média do mês mais frio é superior a $13^{\circ} \mathrm{C}$ e a do mês mais quente, superior a $27^{\circ} \mathrm{C}$ (Setzer, 1946), com precipitação anual de $1450 \mathrm{~mm}$.

Segundo Camargo (1987), o solo da área de estudo é caracterizado como Latossolo Roxo Distrófico com Moderada Textura Argilosa.

\subsection{Escolha das espécies florestais}

As espécies usadas neste trabalho foram escolhidas por serem típicas de programas de recuperação de áreas ciliares desflorestadas com plantio de mudas (Rodrigues et al., 2002). Levando-se em consideração a presença destas em trabalhos de levantamentos florísticos e fitossociológicos de matas ciliares (Ivanauskas et al, 1997; Rodrigues \& Nave, 2000) e seus papeis definidos na sucessão secundária a partir dos estudos de dinâmica de clareiras na floresta (Martins \& Rodrigues, 2002).

Neste trabalho as espécies foram agrupadas em dois grupos funcionais dentro do conceito de "grupo de preenchimento" e "grupo de diversidade". Este modelo foi desenvolvido pelo Laboratório de Ecologia e Restauração Florestal LERF-ESALQ/USP para plantio de mudas em linhas visando um recobrimento rápido do sítio de plantio com alta diversidade (Rodrigues et al., 2001; 2002).

Segundo Rodrigues et al. (2002), o grupo de preenchimento tem como função o rápido recobrimento da área, criando um ambiente favorável ao desenvolvimento dos indivíduos do grupo de diversidade, e ao mesmo tempo desfavorecendo o desenvolvimento de espécies competidoras como gramíneas, lianas, etc, pelo sombreamento rápido da área de recuperação. Dessa forma, esse grupo é constituído de espécies pioneiras e secundárias iniciais. Essas espécies pertencentes ao grupo de preenchimento devem possuir as seguintes características: rápido crescimento e copa frondosa para recobrimento do solo. O florescimento precoce e a produção abundante de sementes em curto prazo 
também são qualidades, permitindo a atração de fauna e a constituição do banco de sementes.

No grupo de diversidade incluem-se todas as demais espécies que podem ou não possuir as características do grupo de preenchimento, mas sempre com um grande número de espécies, ou seja, poucos indivíduos de um grande número de espécies, que é uma característica indispensável para a restauração da dinâmica florestal. Assim nesta categoria incluem-se espécies iniciais e finais da sucessão (Secundárias Iniciais, Secundárias Tardias e/ou Climácicas) que irão constituir a "floresta madura" e que geralmente tem grande interação com a fauna. Estas espécies são criadoras de ambientes para a recolonização da área com outras formas de vida (epífitas, lianas, arbustos, etc), abrigo e puleiro para animais, formação de subosque, etc. (Rodrigues, 2002).

Vale ressaltar que neste trabalho foram utilizadas 20 espécies florestais diferentes para o experimento " $A$ " (10 espécies de preenchimento e 10 espécies de diversidade) e 20 espécies do grupo preenchimento para o experimento "B". Esse número é consideravelmente baixo quando comparada com o plantio a partir de mudas, onde é usado de 20 a 30 espécies de preenchimento e 80 a 100 espécies diversidade (Nave, 2005).

\subsection{Instalação e condução dos experimentos}

Foram realizados neste trabalho dois experimentos em períodos diferentes. O experimento "A" foi implantado em fevereiro de 2003, objetivando testar 20 espécies florestais (10 espécies de preenchimento e 10 espécies de diversidade), em 36 tratamentos diferentes. Com os resultados preliminares positivos do experimento " $A$ " houve a necessidade de instalar um outro experimento ("B") no ano seguinte (janeiro de 2004) para tentar suprir algumas dificuldades iniciais encontradas no experimento inicial ("A"), a fim de otimizar o método: A seguir estão apresentados alguns pontos (positivos e negativos) 
encontrados no experimento "A", os quais auxiliaram no desenvolvimento do experimento " $B$ " atentando sempre para corrigir possíveis falhas ocorridas no experimento inicial ("A"):

1) No experimento "A" as melhores taxas de emergência das espécies ocorreram nos tratamentos onde as sementes foram incorporadas ao solo;

2) No experimento " $A$ " não foi testado o uso de herbicida pré-emergente no preparo da área e, por isso, foram necessários repetidos manejos como capina manual e uso de herbicida pós-emergente para o controle de espécies invasoras (Brachiaria spp., Commelina bengalensis, Portulaca oleraceae entre outras). Além de elevar os custo desse método, possivelmente as sementes em processo de germinação das espécies nativas semeadas, e mesmo as plântulas recém emergidas sofreram alguma interferência por competição com as espécies invasoras agressivas que surgiram na área e/ou sofreram efeito alelopático da Brachiaria decumbens Stapht ou outra espécie invasora ocorrentes na área. Assim, para verificar estes efeitos no experimento "B" foi testado o uso da semeadura a lanço em dois modos diferentes de preparo da área (1-preparo de solo com uso de herbicida pré-emergente e 2- preparo tradicional do solo com uso de herbicida pós-emergente e gradagem) e ainda com e sem incorporação da semente ao solo, uma vez que as análises estatísticas dos dados iniciais do experimento " $A$ " apontaram efeito significativo da germinação quando a semente foi incorporada ao solo;

3) No experimento "A", as sementes usadas na semeadura direta não foram previamente testadas em termos de potencial germinativo ou tratadas para incremento da germinação, com intuito de simular assim uma condição real de uso desse método no campo. Deste modo algumas sementes das espécies usadas no experimento " $\mathrm{B}$ " que foram classificadas dormentes passaram por um processo de tratamento prévio (quebra de dormência) e além da semeadura em campo, as sementes foram também acompanhadas em sementeiras no viveiro, para avaliar seu potencial germinativo já que foi essa a maior deficiência do experimento "A". 
4) Sobre períodos chuvosos, o experimento "A" foi implantado no mês de Fevereiro (2003), considerado uma época tardia pelo fato de que as melhores chuvas na região ocorrem no período de outubro a março (Setzer, 1946). Já o experimento "B" foi implantado no mês de Janeiro (2004) lucrando com mais dias de chuvas em relação ao experimento " $A$ ".

\subsection{Experimento " $A$ "}

O experimento "A" foi instalado em fevereiro de 2003, em delineamento em blocos casualizados (DBC) e 36 tratamentos com três repetições, resultando em 108 parcelas em esquema fatorial $(3 \times 2 \times 3 \times 2)$. Os fatores utilizados e seus níveis estão descritos na Tabela 1.

Cada parcela ocupou uma área de $25 \mathrm{~m}^{2}(5 \times 5 \mathrm{~m})$, totalizando 40 parcelas (36 tratamentos +4 tratamentos adicionais - testemunhas) por bloco (Figura 1). 
Tabela 1. Descrição dos fatores e seus respectivos níveis utilizados para o experimento "A" do projeto de semeadura direta. Fazenda Paineiras, Morro Agudo, SP

\begin{tabular}{|c|c|}
\hline Fatores & Níveis \\
\hline \multirow{3}{*}{ Grupos } & 1- preenchimento \\
\hline & 2- diversidade \\
\hline & 3- preenchimento+diversidade \\
\hline \multirow{2}{*}{ Sementes } & 1- puras \\
\hline & 2- peletizadas \\
\hline \multirow[b]{2}{*}{ Substratos } & 1- só sementes \\
\hline & $\begin{array}{l}\text { 2- sementes+matéria orgânica } \\
\text { 3- sementes+adubo+matéria } \\
\text { orgânica }\end{array}$ \\
\hline \multirow{2}{*}{ Incorporação ao solo } & 1- sementes incorporadas \\
\hline & 2- sementes não incorporadas \\
\hline
\end{tabular}

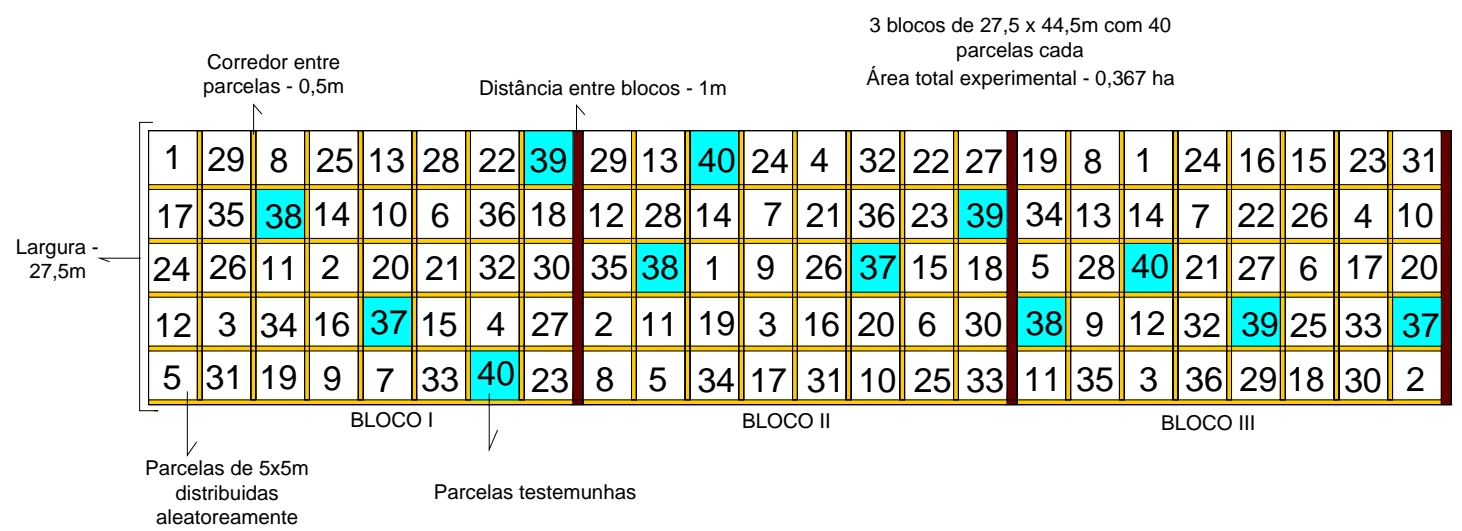

Figura 1 - Esquema de implantação dos tratamentos e testemunhas nas parcelas de acordo com o delineamento experimental de blocos casualizados, do experimento " $A$ " do projeto de semeadura direta. Fazenda Paineiras, Morro Agudo, SP 
As parcelas que receberam tratamentos com matéria orgânica foi usada uma média de 180 litros ou $121 \mathrm{~kg}$ de esterco bovino curtido, o que representa 72.000 litros ou $48.400 \mathrm{~kg}$ por hectare. O esterco bovino foi distribuído uniformemente na parcela com auxílio de um rastelo de jardinagem (Figura 2).

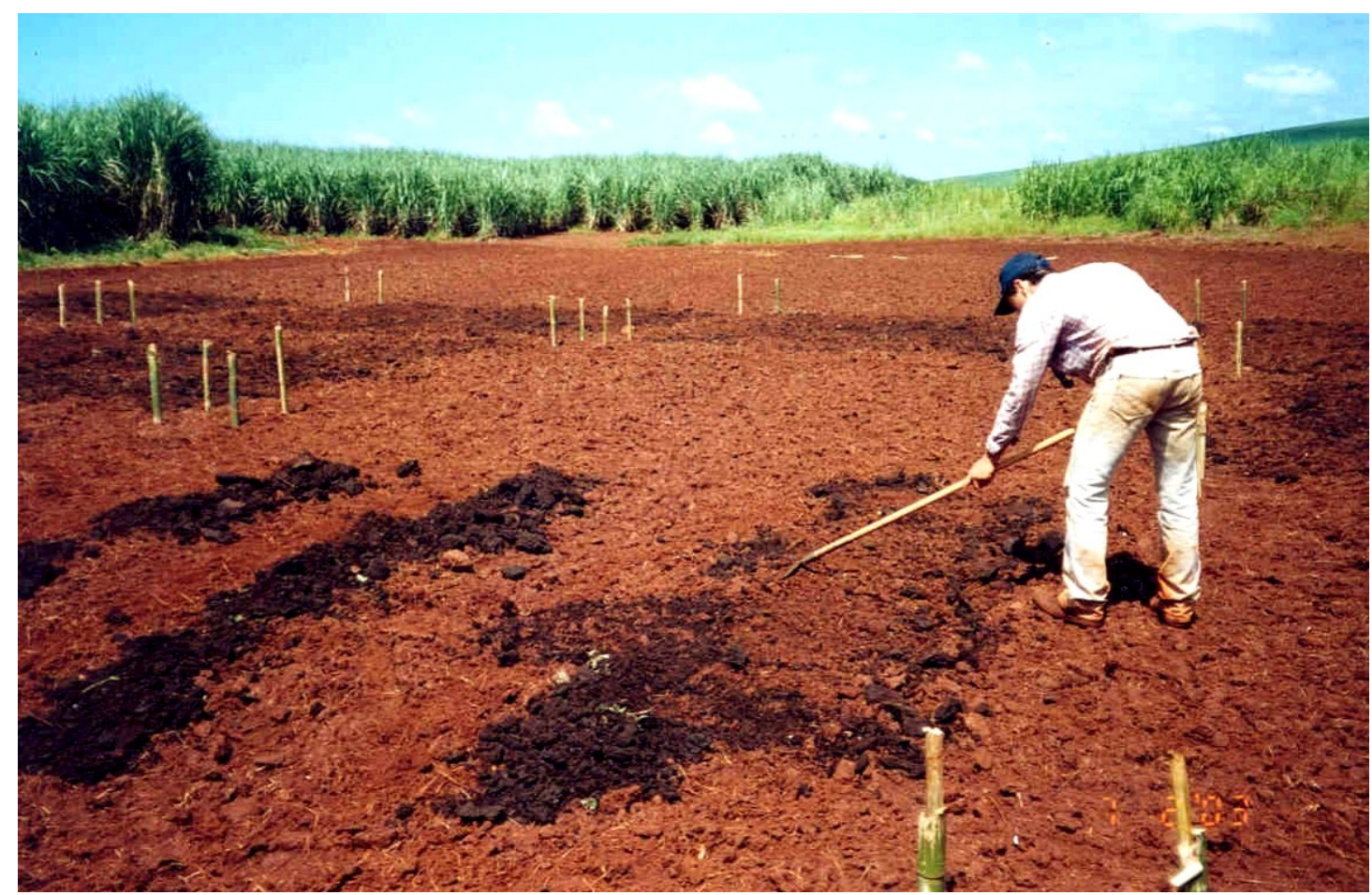

Figura 2 - Parcela onde foi utilizado esterco bovino, em destaque distribuição uniforme usando rastelo de jardinagem, no experimento " $A$ " do projeto de semeadura direta. Fazenda Paineiras, Morro Agudo, SP

O adubo utilizado nos tratamentos foi o fosfato (superfosfato simples), semeado a lanço na proporção de 2,5 kg por parcela deste tratamento, elevando a concentração de fósforo no solo para $100 \mathrm{mg} / \mathrm{dm}^{3}$ ou $1000 \mathrm{~kg} / \mathrm{ha} \mathrm{(Figura} \mathrm{3).}$ 


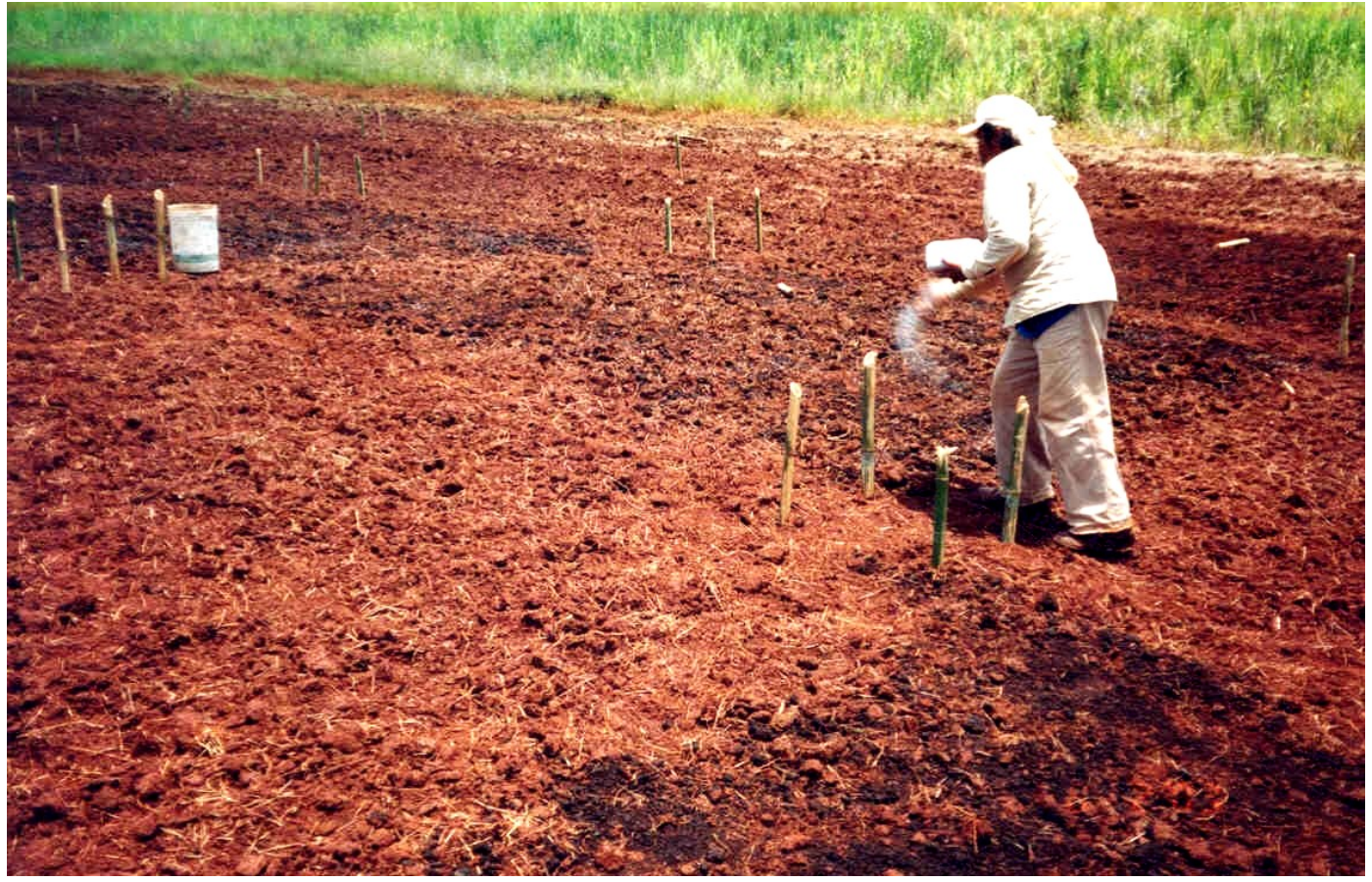

Figura 3 - Distribuição a lanço do superfosfato simples nas respectivas parcelas do experimento "A" do projeto de semeadura direta. Fazenda Paineiras, Morro Agudo, SP

As parcelas foram demarcadas com estacas de bambu e espaçadas 0,5m uma das outras, formando um corredor para viabilizar a manutenção das mesmas (Figura 4). O experimento ocupou uma área total de $3670 \mathrm{~m}^{2}$ e uma área útil semeada de $2850 \mathrm{~m}^{2}$. A análise química do solo da área encontra-se em anexo (Anexo A). 


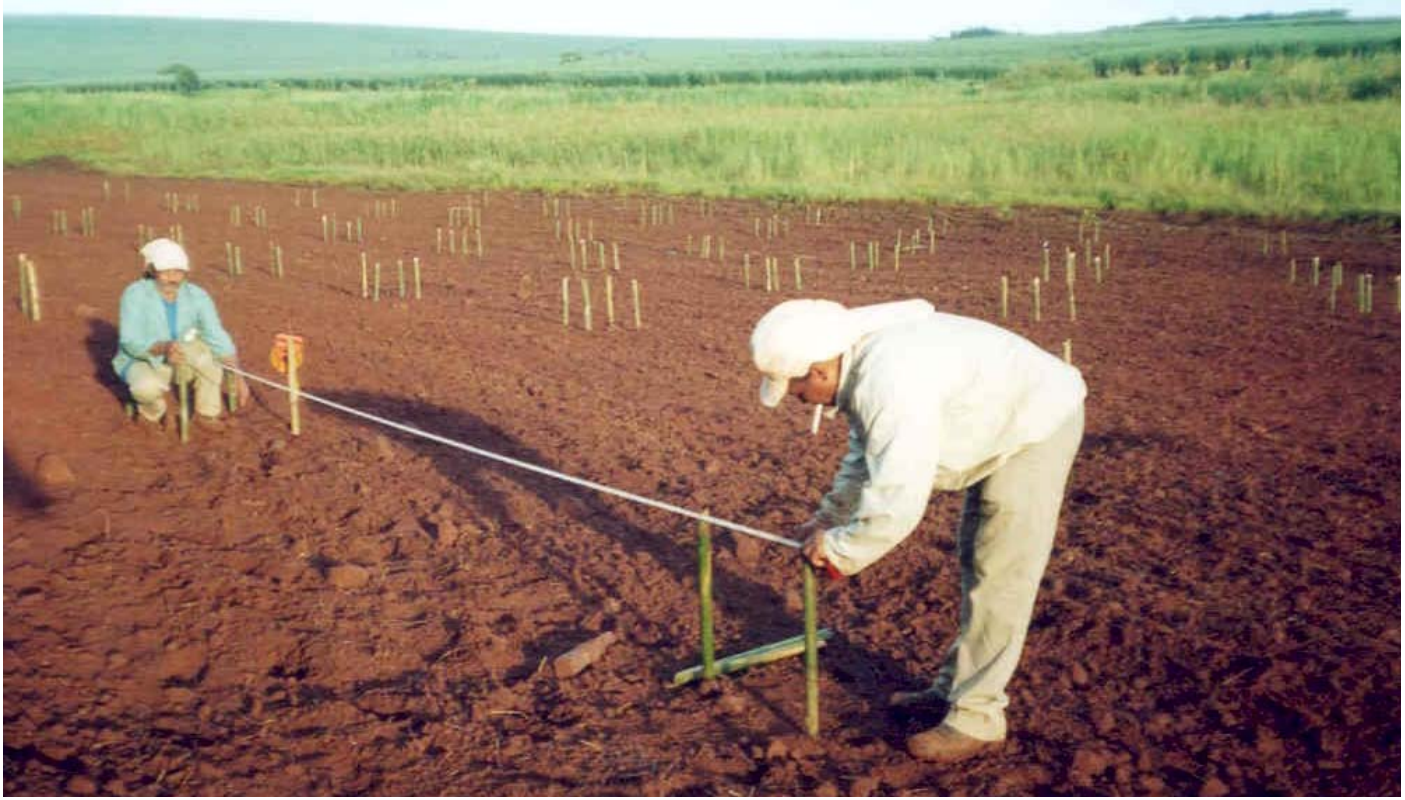

Figura 4 - Implantação das parcelas na área do experimento "A" do projeto de semeadura direta após o preparo do solo. Fazenda Paineiras, Morro Agudo, SP

As parcelas que receberam tratamento com espécies de preenchimento semearam-se 411 sementes de 10 espécies florestais (pioneiras e secundárias iniciais), 338 sementes de 10 espécies do grupo de diversidade (pioneiras, secundárias iniciais e secundárias tardias) de 749 sementes de 20 espécies (10 espécies do grupo preenchimento e 10 do grupo de diversidade), o que definiu neste último um banco de sementes com densidade superior aos demais. As sementes foram semeadas a lanço em cada parcela e para incorporação ao solo foi utilizado um soquete de madeira que enterrava a semente numa profundidade de 0,5 a $1 \mathrm{~cm}$ no solo (Figuras 5 e 6 ). 


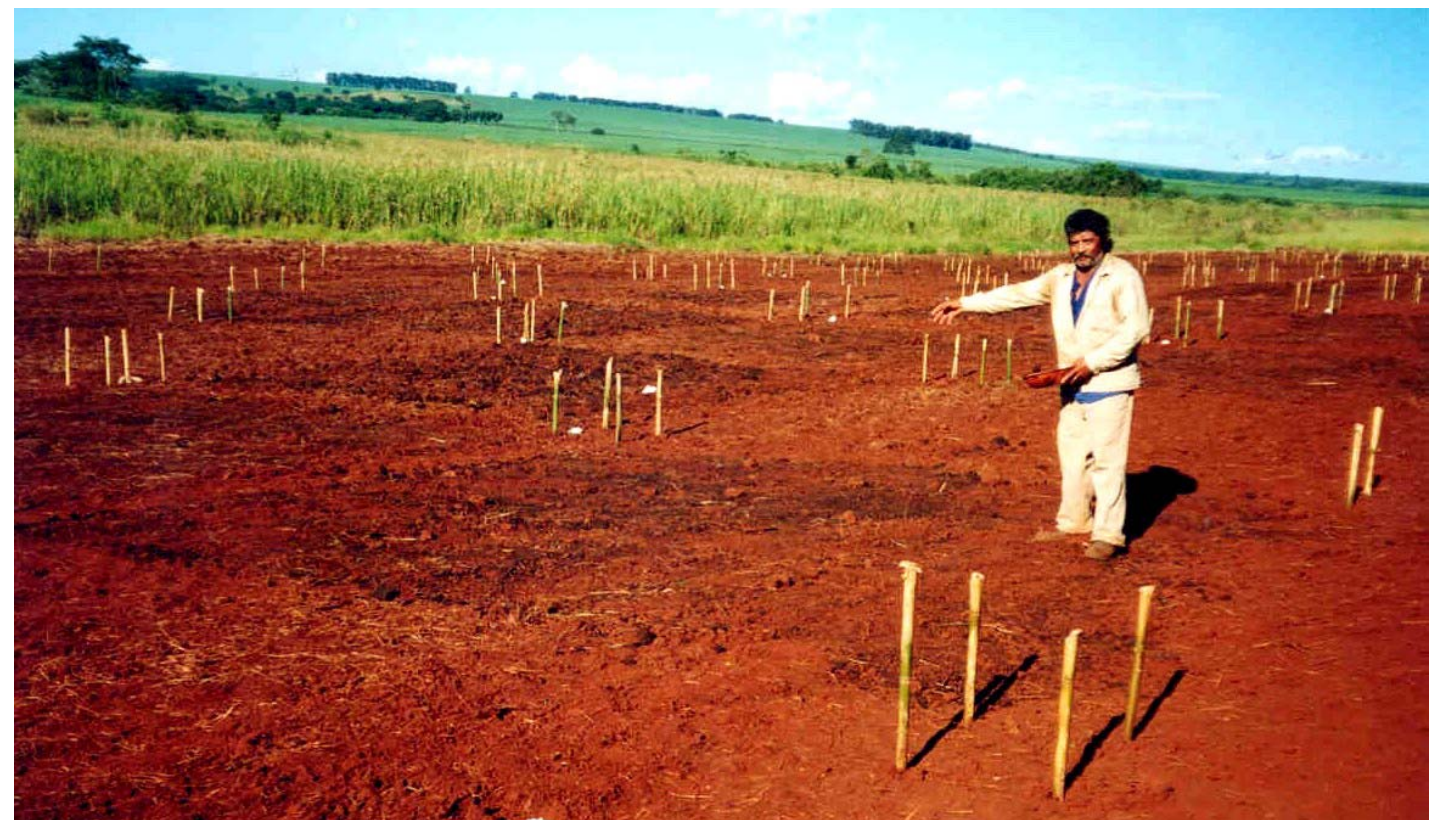

Figura 5 - Semeadura a lanço das espécies florestais na parcela do experimento "A" do projeto de semeadura direta. Fazenda Paineiras, Morro Agudo, SP 


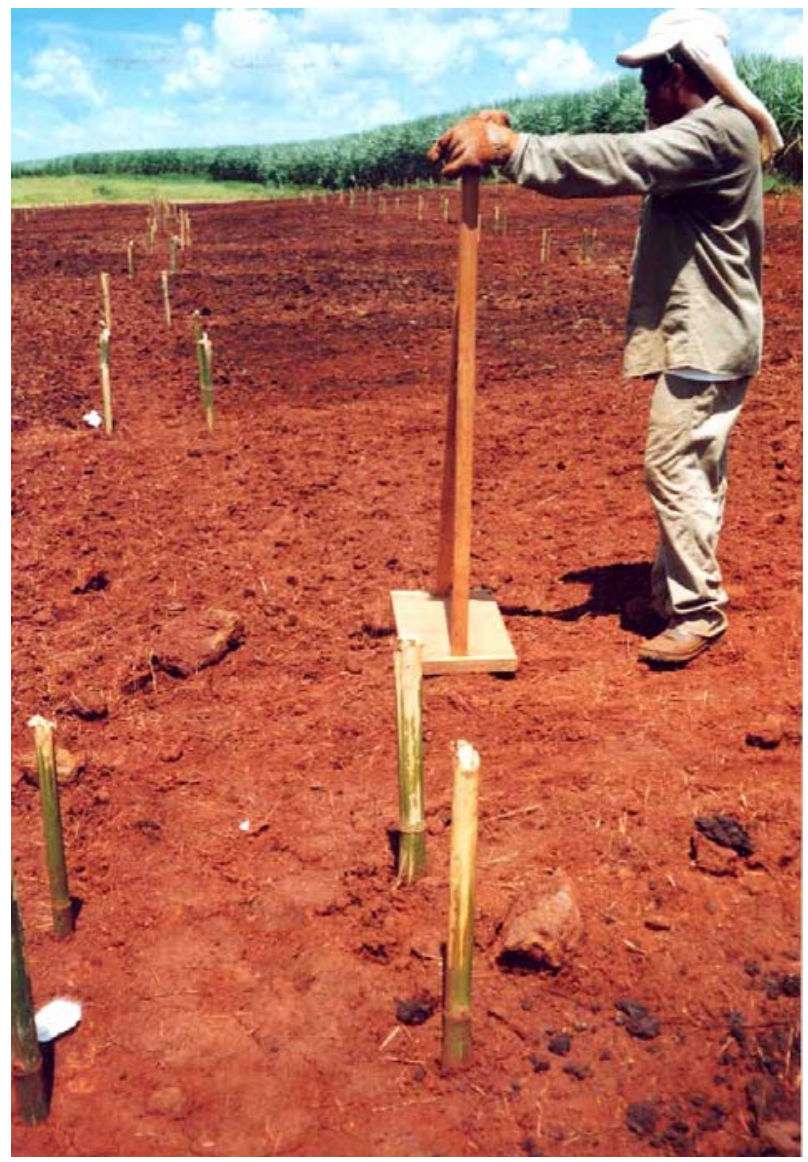

Figura 6 - Incorporação das sementes ao solo na parcela do experimento "A" do projeto de semeadura direta, em destaque o soquete de madeira utilizado, Fazenda Paineiras, Morro Agudo, SP

As sementes peletizadas de um dos tratamentos passaram por um processo de peletização manual. Nesse processo as sementes foram colocadas em um recipiente refratário e adicionado gel hidrofílico em pó (BIOSOLO ${ }^{\circledR}$ ) e uma cola a base de acetato de polivinila (PVA), sendo intensamente revolvidos para uniformização da distribuição do gel no entorno das sementes. Esse processo foi realizado separadamente para cada espécie do experimento. Após secagem em temperatura ambiente, as sementes foram acondicionadas em sacos de papel para posterior semeadura no campo. O gel hidrofílico foi usado 
somente na forma de material inerte não sendo adicionado nenhum tipo de nutriente ou defensivo no pélete.

\subsubsection{Preparação do sítio de plantio}

O experimento "A" foi instalado em uma área ciliar (Área de Preservação Permanente) nas margens de um campo úmido antrópico, com um histórico de aproximadamente 20 anos de ocupação com pastagem de braquiária (Brachiaria decumbens Stapht). O preparo da área iniciou-se em outubro de 2002, visando diminuir o banco de sementes de braquiária sem uso de herbicidas pré-emergentes, evitando com isso, o possível efeito desse herbicida sobre as sementes nativas que seriam semeadas. A área foi preparada inicialmente com herbicida sistêmico glifosate (5l/ha), 20 dias após aplicação, o solo foi gradeado e nivelado e após dois meses repetiu-se os mesmos procedimentos devido à nova infestação de braquiária e outras ervas daninhas (Figura 7). 


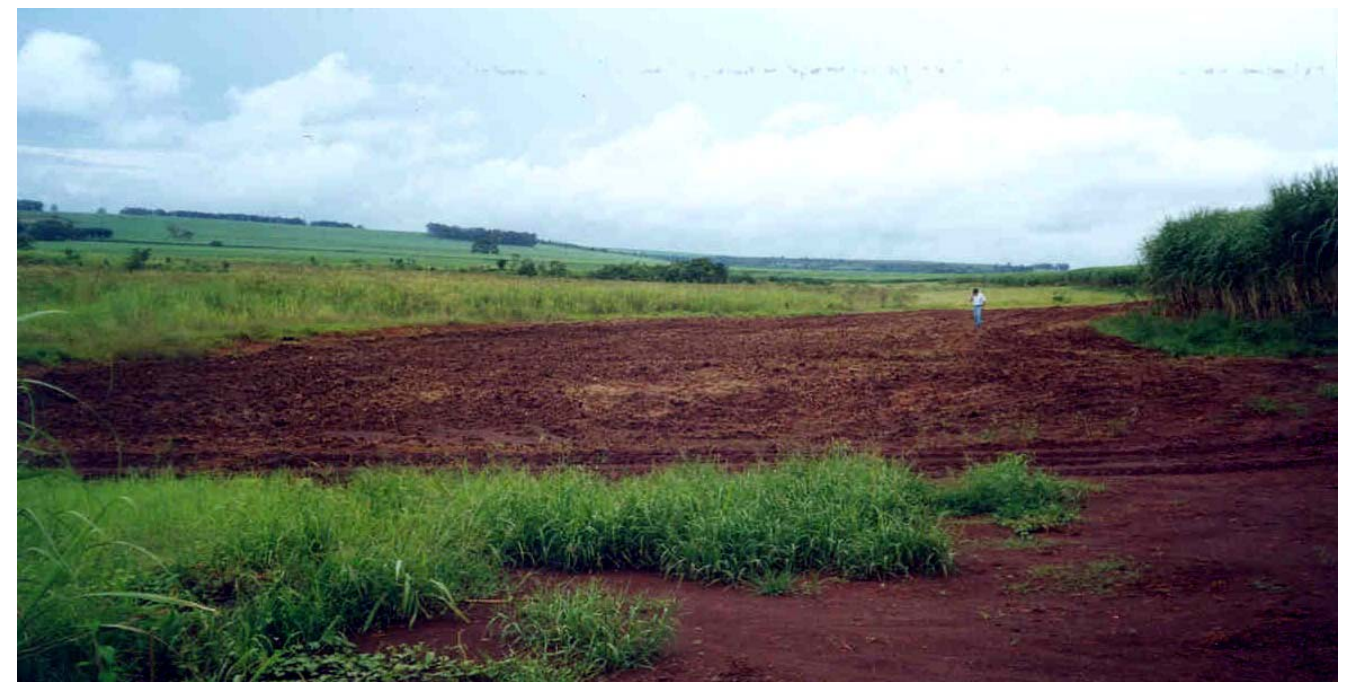

Figura 7 - Aspecto geral da área do experimento "A" do projeto de semeadura direta após o preparo do solo. Fazenda Paineiras, Morro Agudo, SP

As sementes das espécies florestais foram semeadas no dia 9 de fevereiro de 2003. Após 40 dias da semeadura foi realizada uma adubação a lanço, utilizando-se $375 \mathrm{~g}$ de nitrato de amônia e $413 \mathrm{~g}$ de cloreto de potássio em área total o que representa 150 e $165 \mathrm{~kg}$ por hectare respectivamente. Nesse mesmo período foi feito o controle de formigas, pulverizando com bomba costal em área total, o produto REGENT ${ }^{\circledR} 800$ WG na proporção de $10 \mathrm{~g} / 20$.

\subsubsection{Tratos culturais}

Durante os quatros meses após a semeadura, foram realizados cinco tratos culturais (controle de ervas daninhas) de modo a não comprometer a emergência e o estabelecimento das plântulas das espécies estudadas, aos 30 , 40, 55, 85 e 120 dias após a semeadura. O controle aos 30 dias foi realizado manual (arranquio) e com herbicida glifosate, por ainda não haver emergido as espécies semeadas. Aos 40, 55 e 120 dias foram realizados o desbaste de competidores com capina manual e para facilitar a visualização das mudas 
todas foram marcadas com uma estaca de bambu (Figura 8). No quarto período, aos 85 dias, foi utilizado o herbicida glifosate aplicado seletivamente nas espécies competidoras, uma vez que nesse período algumas das espécies semeadas encontravam-se emergidas, para isso todas as mudas foram protegidas fisicamente, usando um recipiente plástico (Figura 9). No terceiro e quinto período (55 e 120 dias), além do controle de espécies invasoras foi realizado também o revolvimento do solo com enxada em área total, visando expor o banco de sementes restantes ainda não germinadas, potencializando o processo de germinação.

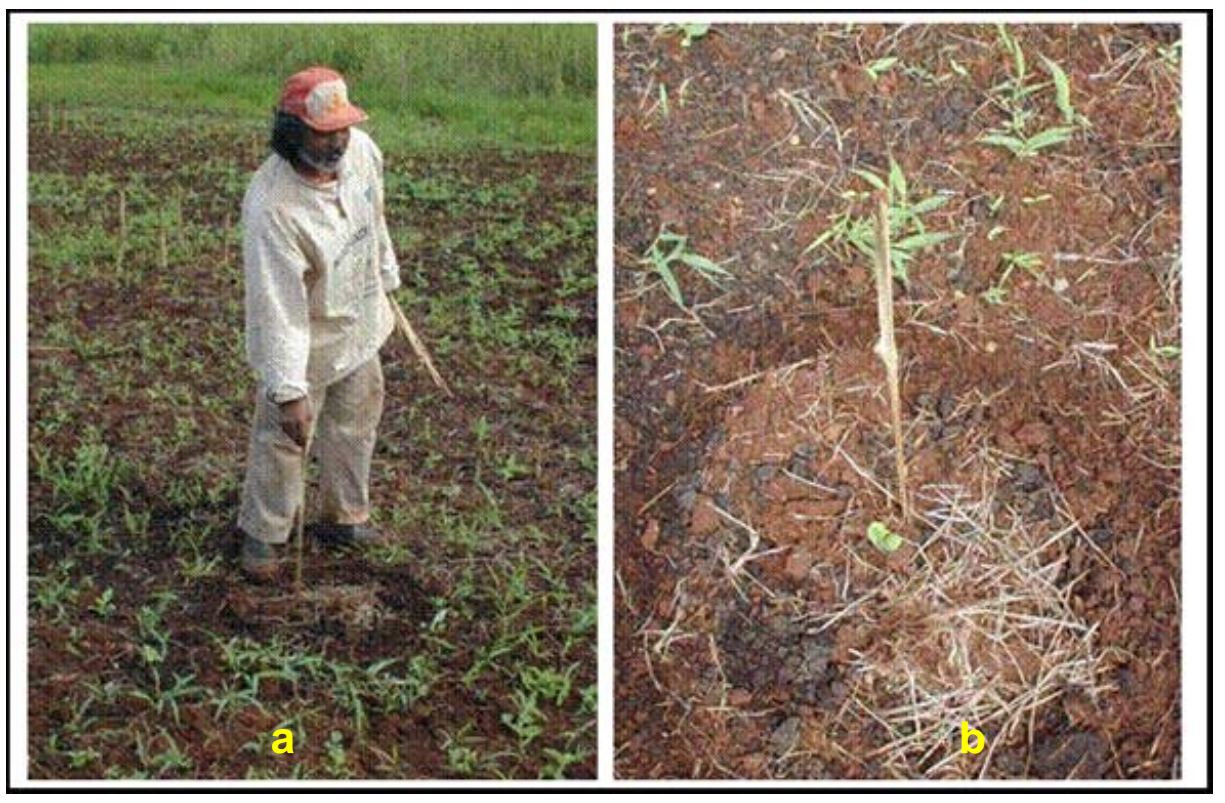

Figura 8 - a) Coroamento e estaqueamento de plântulas com estaca de bambu e b) Aspecto de uma plântula coroada e marcada, para facilitar o controle de competidores no experimento "A" do projeto de semeadura direta. Fazenda Paineiras, Morro Agudo, SP 


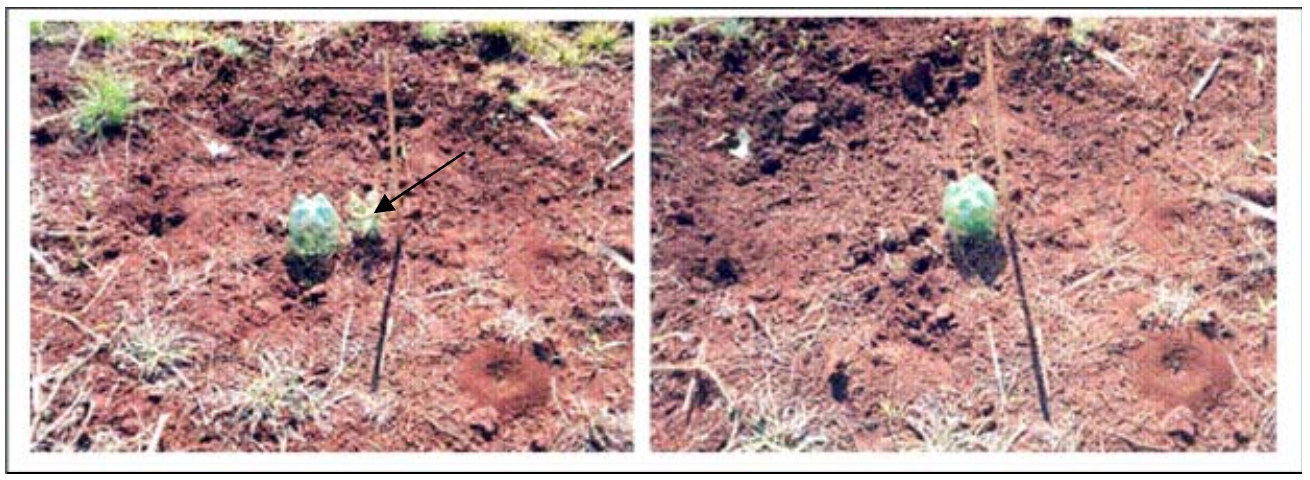

Figura 9 - Plântula protegida para aplicação do herbicida glifosate no experimento "A", em destaque o protetor físico (garrafa plástica), no projeto de semeadura direta. Fazenda Paineiras, Morro Agudo, SP

Nos primeiros quatro meses, após implantação do experimento, não foi realizada nenhuma irrigação artificial, sendo que neste período a área experimental foi favorecida com as chuvas que se estenderam até o mês de maio (Figura 10). A primeira irrigação artificial realizou-se aos 120 dias após a semeadura, utilizando um caminhão pipa com capacidade de 14.000 litros d'água onde foi irrigado 3,78mm em área total. Na Figura 11 pode-se observar a o acumulado de precipitação relativa a 12 meses após a implantação do experimento no campo. 


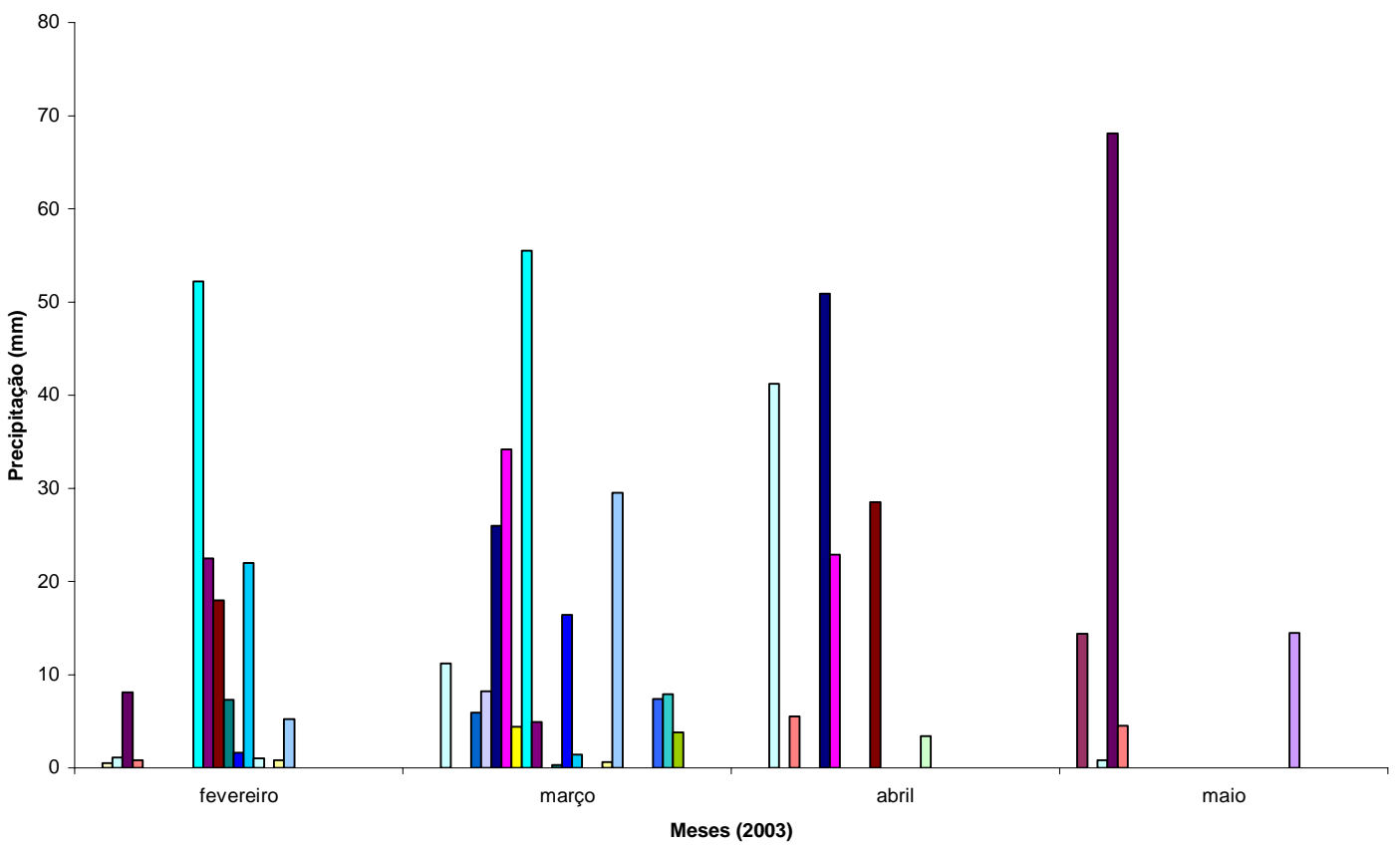

Figura 10 - Precipitação diária dos meses fevereiro, março, abril e maio do ano de 2003 emitida pelo pluviômetro instalado na Usina Vale do Rosário, Orlândia, SP, 8 km aproximado em linha reta da área experimental do projeto de semeadura direta 


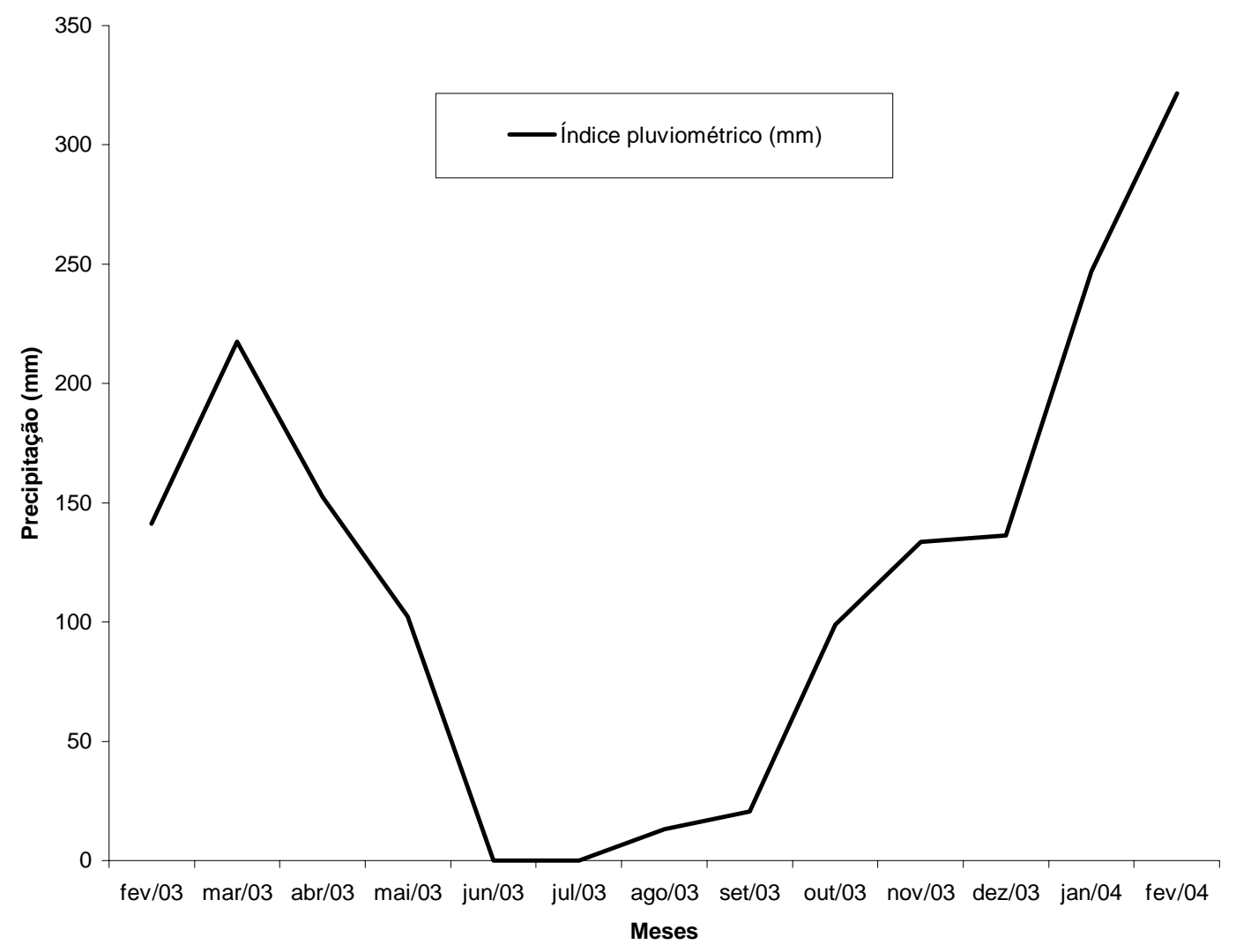

Figura 11 - Índice pluviométrico mensal relativo a 1 ano após a implantação do experimento em campo, emitido pelo pluviômetro instalado na Usina Vale do Rosário, Orlândia, SP, 8 km aproximado em linha reta da área experimental do projeto de semeadura direta

\subsubsection{Densidade de sementes por espécies}

Um número muito alto de sementes para uso na semeadura direta além de elevar o custo poderá também caracterizar um desperdício, por haver a necessidade na pós-emergência da realização de desbaste de plântulas. Deste modo, para a estipulação do número de sementes que foram semeadas neste experimento, considerou-se previamente os vários fatores que poderiam comprometer o sucesso da semeadura em campo já identificado por alguns 
autores como Smith (1986); Sun \& Dickinson (1996), Camargo et al. (2002), entre outros. Os fatores comprometedores citados na maioria das vezes são: 1Taxa de germinação das sementes (qualidade do lote), 2- Predação de sementes e plântulas (por fungos, insetos, aves, mamíferos, entre outros), 3competição com espécies invasoras e 4- disponibilidade de água no local do plantio.

Partindo deste princípio a densidade usada neste experimento foi definida baseando-se nas taxas de pegamento (teor de germinação) das espécies utilizadas neste experimento descritas por Lorenzi (1992), PinãRodrigues (1992), Carvalho (1994) e Barbosa et al. (1997a), considerando também uma taxa de predação de sementes pós-semeadura estipulada de 50\% para sementes grandes, 30\% para sementes médias e 20\% para sementes pequenas. Foi incrementada ainda uma margem de segurança com adição de $50 \%$ de sementes para todas as espécies (considerando predação e competição pós-emergência e indisponibilidade de água no solo pós-semeadura). Assim, como exemplo, espécies com teor de germinação de 60\% (40\% não germina) e $50 \%$ de predação (considerando sementes grandes) somando-se ainda com + $50 \%$ (margem de segurança) resultou-se em uma densidade de $140 \%$ a mais de sementes a serem semeadas. Esta estipulação foi feita por não existir ainda relatos em literatura sobre o número exato de sementes que deve ser utilizado em estudos de revegetação por meio da semeadura direta de espécies nativas de florestas tropicais.

Apesar das sementes das espécies florestais utilizadas neste experimento não terem sido avaliadas em laboratório quanto à viabilidade, as mesmas foram selecionadas no processo de contagem antes da semeadura em campo. Neste processo foram escolhidas sempre as sementes mais vigorosas.

Nas Tabelas 2 e 3 encontram-se descritas a relação das espécies e a densidade de sementes utilizadas neste experimento, com o total por parcela e por hectare. Uma descrição geral de todas as espécies utilizadas neste experimento pode ser encontrada no Anexo B. 
Tabela 2. Relação das espécies florestais e respectivas densidades de sementes do grupo de preenchimento utilizadas no experimento " $A$ " no projeto de semeadura direta. Fazenda Paineiras, Morro Agudo, SP

\begin{tabular}{|c|c|c|c|c|}
\hline Espécies & Nome vulgar & Família & $\begin{array}{c}\text { Qtde. } \\
\text { sementes/ } \\
\text { parcela }\end{array}$ & $\begin{array}{c}\text { Qtde. } \\
\text { sementes/ha }\end{array}$ \\
\hline Acacia polyphylla DC. & monjoleiro & Mimosaceae & 24 & 9.600 \\
\hline Albizia hasslerii (Chodat) Burr. & farinha - seca & Mimosaceae & 38 & 15.200 \\
\hline $\begin{array}{l}\text { Anadenanthera falcata Benth. } \\
\text { Spreng. }\end{array}$ & angico & Mimosaceae & 30 & 12.000 \\
\hline Bauhinia forficata Link & pata - de - vaca & Caesalpiniaceae & 40 & 16.000 \\
\hline Casearia sylvestris Sw. & guaçatonga & Flacourtiaceae & 66 & 26.400 \\
\hline Cecropia pachystachya Trec. & embaúba & Cecropiaceae & 66 & 26.400 \\
\hline Platypodium elegans Vog. & $\begin{array}{l}\text { jacarandá - do - } \\
\text { campo }\end{array}$ & Fabaceae & 39 & 15.600 \\
\hline Pterogyne nitens Tul. & $\begin{array}{l}\text { amendoim - } \\
\text { bravo }\end{array}$ & Fabaceae & 30 & 12.000 \\
\hline Solanum erianthum D. Don & fumo - bravo & Solanaceae & 30 & 12.000 \\
\hline Trema micrantha (L.) Blum. & pau - pólvora & Ulmaceae & 48 & 19.200 \\
\hline Totais & 10 & 7 & 411 & 164.400 \\
\hline
\end{tabular}

Tabela 3. Relação das espécies florestais e respectivas densidades de sementes do grupo de diversidade utilizadas no experimento " $A$ " no projeto de semeadura direta. Fazenda Paineiras, Morro Agudo, SP

\begin{tabular}{lcccc}
\hline \multicolumn{1}{c}{ Espécies } & Nome vulgar & Família & $\begin{array}{c}\text { Qtde. } \\
\text { sementes/ } \\
\text { parcela }\end{array}$ & $\begin{array}{c}\text { Qtde } \\
\text { sementes/ha }\end{array}$ \\
\hline Cedrella fissilis Vell. & cedro & Meliaceae & 48 & 19.200 \\
Croton floribundus Spreng. & capixingui & Euphorbiaceae & 42 & 16.800 \\
Citharexyllum myrianthum & pau-viola & Verbenaceae & 30 & 12.000 \\
Cham. & maria - pobre & Sapindaceae & 30 & 12.000 \\
Dilodendron bipinnatum Radkl. & jenipapo & Rubiaceae & 36 & 14.400 \\
Genipa americana L. & caroba & Bignoniaceae & 30 & 12.000 \\
Jacaranda cuspidifolia Mart. & aroeira - & Anacardiaceae & 30 & 12.000 \\
Myracrodruon urundeuva Fr. All. & verdadeira & - & 30 & 12.000 \\
Ormosia arborea (Vell.) Harms & olho - de - cabra & Fabaceae & 30 \\
Psidium guajava L. & goiabeira & Myrtaceae & 30 & 12.000 \\
Zanthoxylum rhoifolium Lam. & mamica - de - & Rutaceae & 32 & 12.800 \\
Totais & porca & 10 & 338 & 135.200 \\
\hline
\end{tabular}


3.5 Experimento "B"

\subsubsection{Experimento de campo}

A implantação do experimento "B" foi realizada em janeiro de 2004 . O delineamento utilizado neste experimento foi de blocos casualizados (DBC), em esquema fatorial $(2 \times 2)$, com 8 repetições. Como fator $A$ foram consideradas duas condições de preparo de solo (com e sem o uso de herbicida préemergente), como fator B duas condições de incorporação da semente (com e sem incorporação da semente ao solo). Cada parcela ocupou uma área de $25 \mathrm{~m}^{2}$ $(5 \times 5 \mathrm{~m})$, totalizando 6 parcelas (4 tratamentos e 2 tratamentos adicionais testemunhas) por bloco (totais de 32 parcelas tratamentos e 16 testemunhas). As parcelas foram demarcadas com estacas de bambu e espaçadas $1 \mathrm{~m}$ umas das outras, formando um corredor para viabilizar o manejo das mesmas e evitar possíveis interferências do herbicida pré-emergente sobre as parcelas que não receberam este tratamento. O experimento ocupou uma área de $2160 \mathrm{~m}^{2}$ e uma área útil de $1200 \mathrm{~m}^{2}$ (Figuras 12 e 13). Na figura 14 observa-se a precipitação diária dos 5 primeiros meses do ano 2004 na área experimental. 


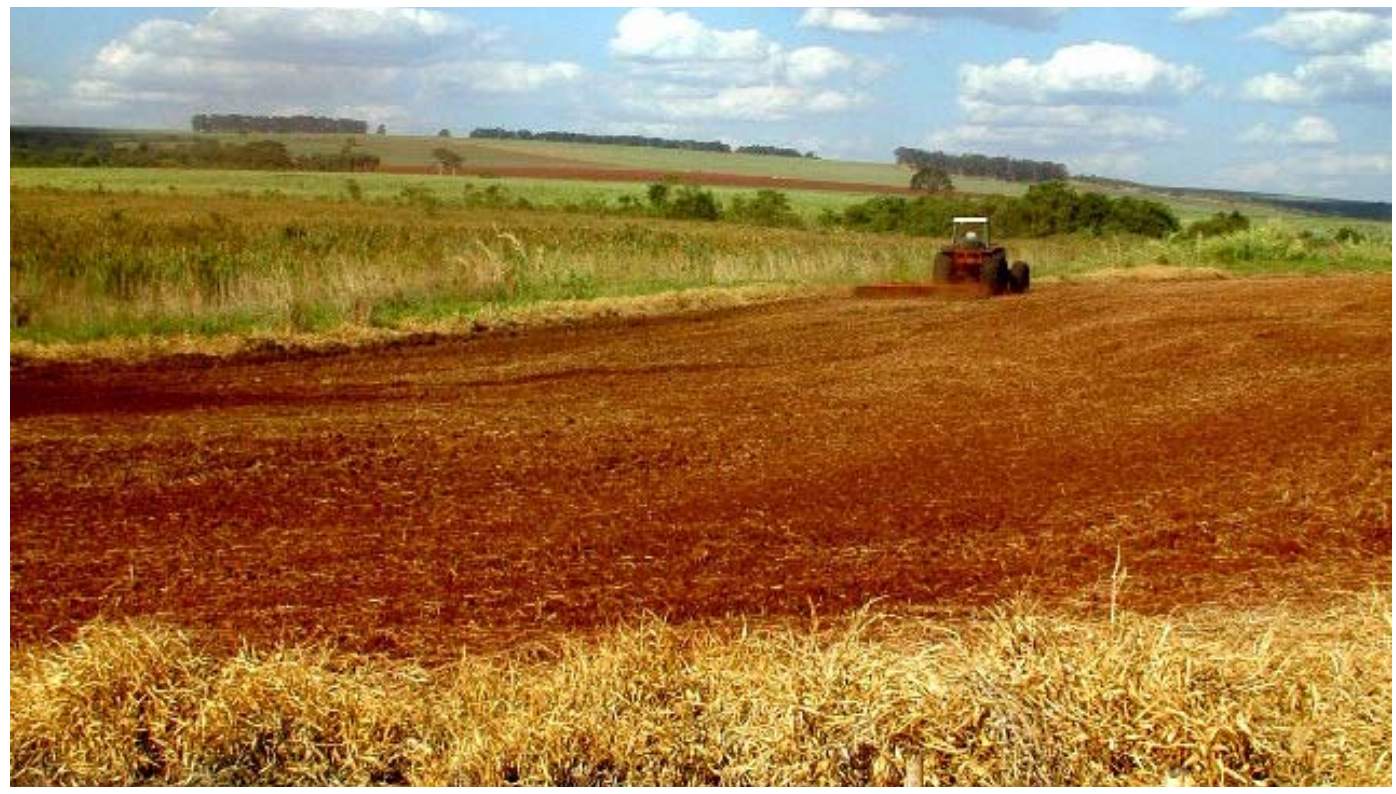

Figura 12 - Aspecto geral da área do experimento "B" do projeto de semeadura direta durante o preparo do solo com gradagem leve. Fazenda Paineiras, Morro Agudo, SP

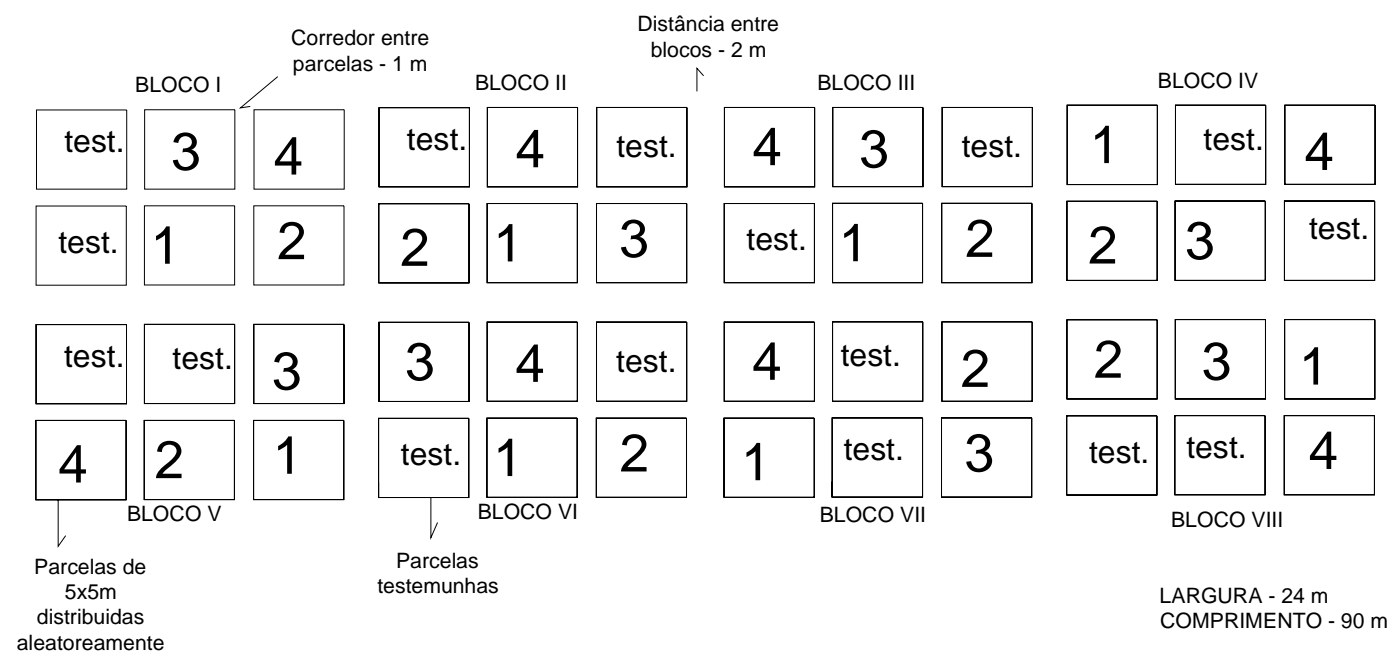

Figura 13 - Esquema de implantação dos tratamentos e testemunhas nas parcelas de acordo com o delineamento experimental de blocos casualizados, do experimento " $\mathrm{B}$ " do projeto de semeadura direta. Fazenda Paineiras, Morro Agudo, SP 


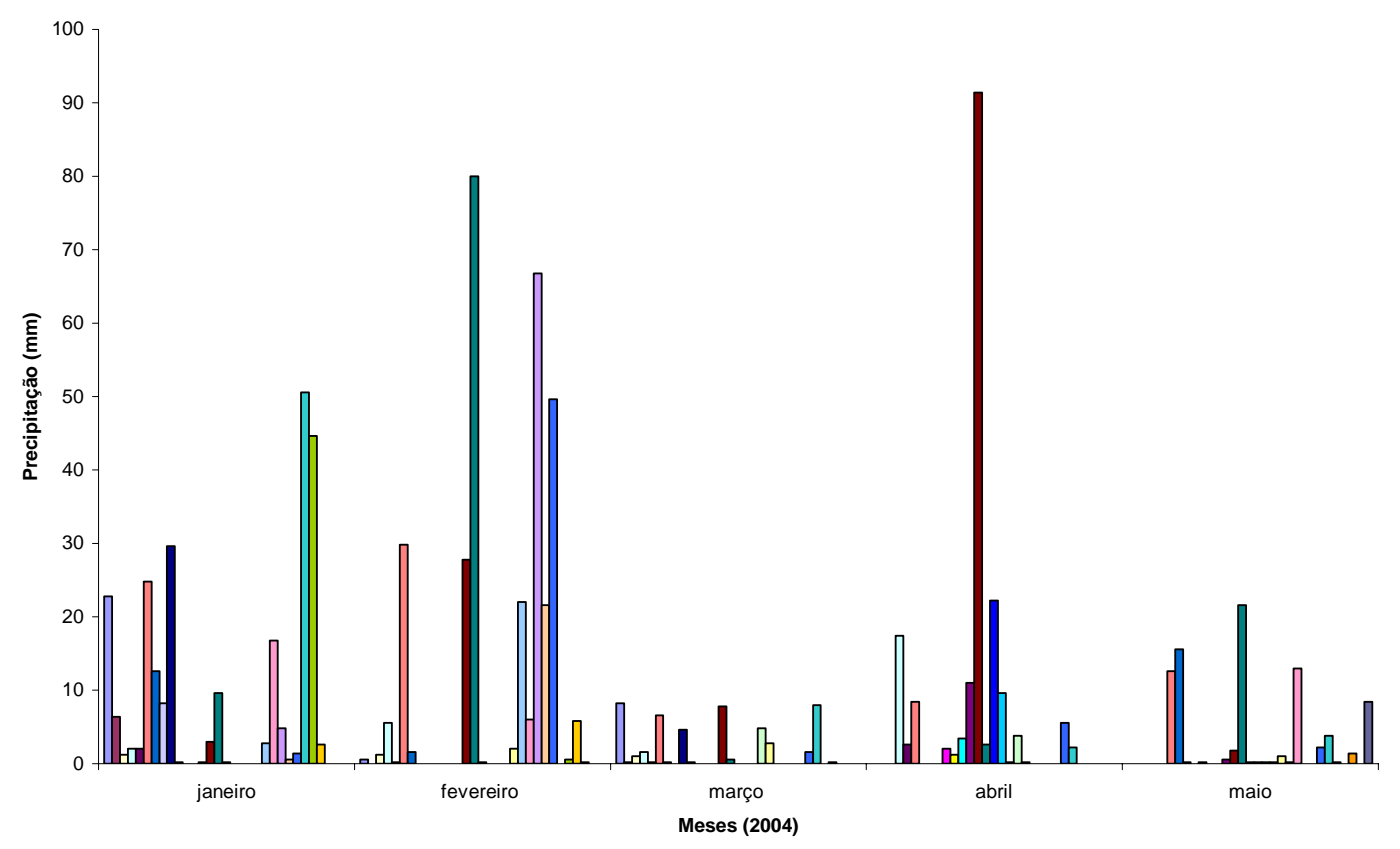

Figura 14 - Precipitação diária dos 5 primeiros meses do ano de 2004 emitida pelo pluviômetro instalado na Usina Vale do Rosário, Orlândia, SP, $8 \mathrm{~km}$ aproximado em linha reta da área experimental do projeto de semeadura direta

\subsubsection{Densidade de sementes por espécies}

$\mathrm{Na}$ tentativa de reduzir os custos com as sementes das espécies florestais aqui utilizadas, a densidade de sementes usadas neste experimento foi inferior a do experimento " $A$ ". No experimento " $A$ " foram gastos cerca de $R \$$ 1420,00/ha na aquisição de sementes de espécies do grupo de preenchimento (10 espécies florestais). Neste experimento ("B") os custos com sementes foram de $\mathrm{R} \$$ 158,54/ha com espécies do grupo de preenchimento (20 diferentes espécies florestais), sendo três delas (Platypodium elegans, Pterogyne nitens e Jacaranda cuspidifolia) as que previamente apresentaram as melhores taxas de emergência no experimento "A". 
Embora não tenha apresentado boa emergência de plântulas no experimento "A" a espécie Acacia polyphylla foi novamente inserida neste experimento ("B"), além de outras duas (Bauhinia forficata, Cecropia pachystachya) que foram testadas no primeiro experimento ("A") que não apresentaram nenhum indivíduo emergido até no período de implantação deste experimento ("B") - janeiro de 2004. Essas três espécies foram novamente inseridas neste experimento ("B") por serem típicas em programas de recuperação de áreas degradadas (Rodrigues et al., 2003).

Sendo assim para as espécies Acacia polyphylla DC. (monjoleiro), Bauhinia forficata Link (pata - de - vaca), Cecropia pachystachya Trec. (embaúba), Enterolobium contortisiliquum (Vell.) (orelha-de-negro), Erythryna speciosa Andrews (mulungu), Jacaranda cuspidifolia Mart. (caroba), Lafoensia pacari St. Hil. (dedaleiro), Lonchocarpus muehlbergianus (Tull.) Malme (embira de - sapo), Piptadenia gonoacantha (Mart.) J.F.Macbr. (pau-jacaré), Prunus myrtifolia (L.) Urb. (pessegueiro - bravo), Pterogyne nitens Tul. (amendoim bravo), Schizolobium parahyba (Vell) Blake (guapuruvu), Senna alata (L.) Roxb. (mata - pasto), Senna multijuga (Rich.) H.S. Irwin \& Barneby (pau - cigarra), Sesbania sesban (L.) Merr. (aleluiero), foram semeadas 3 sementes por parcela, para Aegiphilla sellowiana Cham (tamanqueira), Peltophorum dubium (Spreng.) Taub. (canafístula), Platypodium elegans Vog. (jacarandá - do - campo), Pterocarpus violaceus Vog. (aldrago), Schinus terebinthifolius Raddi (aroeira pimenteira) foram semeadas 6 sementes por parcela. Assim, em cada parcela, foram semeadas 75 sementes, totalizando 2.400 sementes em 32 parcelas (30.000 sementes/ha). Neste experimento calculou-se a densidade das sementes, esperando-se obter pelo menos uma semente germinada de cada espécie por parcela e, portanto um total de 20 indivíduos por parcela de $25 \mathrm{~m}^{2}$, ou seja, em cada 3 ou 6 sementes que foram semeadas, acreditava-se que pelo menos uma delas conseguiria germinar.

As sementes foram semeadas a lanço em cada parcela. Para incorporação das sementes ao solo nas parcelas com este tratamento, foi 
utilizado um rolete de metal (com aproximadamente $50 \mathrm{~kg}$ ) desenvolvido pela Usina Vale do Rosário, incorporando a semente 0,5 a $1 \mathrm{~cm}$ no solo (Figura 15).

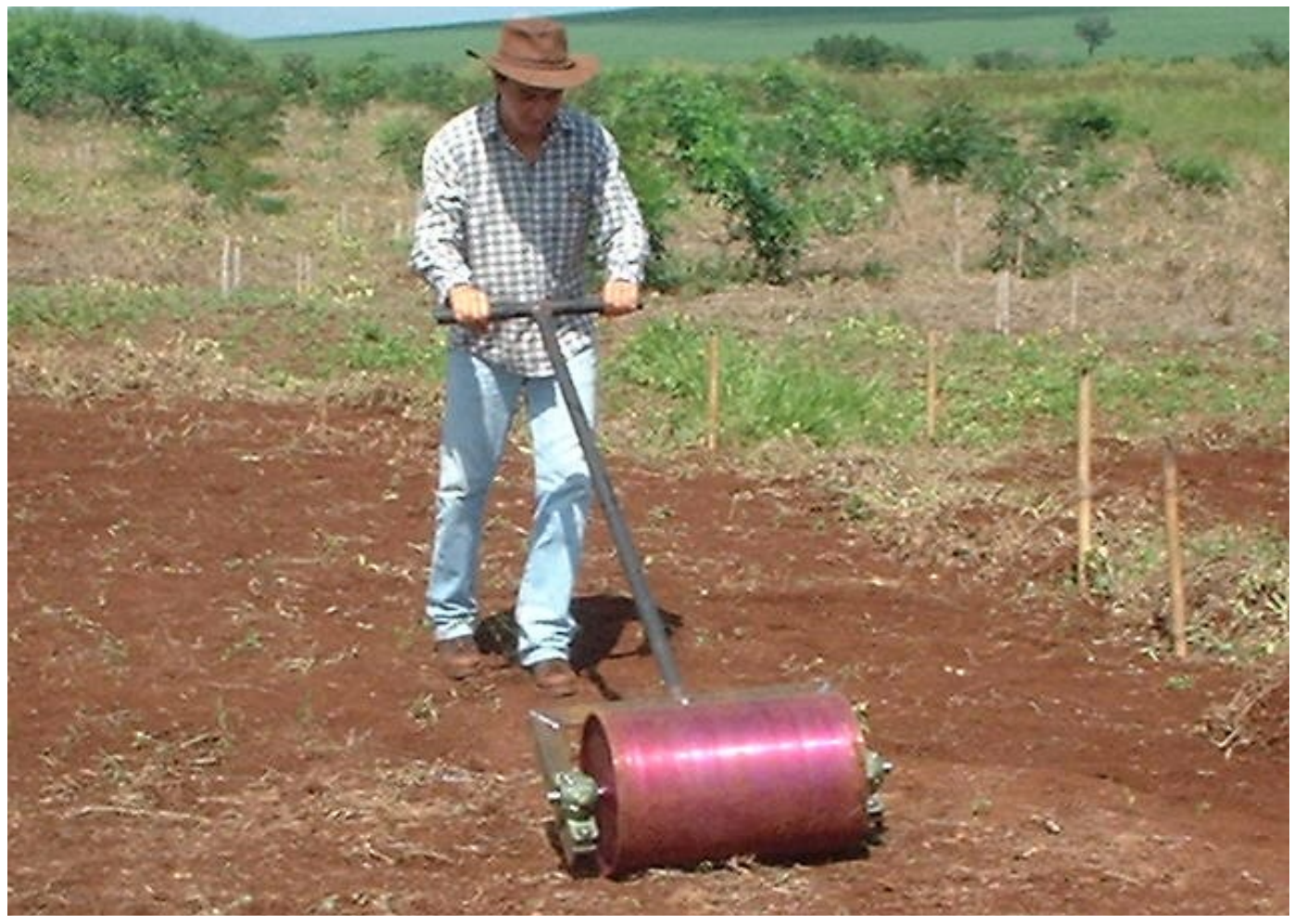

Figura 15 - Incorporação das sementes ao solo na parcela do experimento "B" do projeto de semeadura direta, em destaque o rolete de metal utilizado. Fazenda Paineiras. Morro Agudo, SP

\subsubsection{Preparo do sítio de plantio}

Este experimento foi instalado ao lado do experimento "A", também em uma área ciliar (Área de Preservação Permanente) nas margens de um campo úmido antrópico com as mesmas características da área do experimento "A". O preparo da área iniciou-se em outubro de 2003. A área foi preparada inicialmente com herbicida sistêmico glifosate (5I/ha), 15 dias após a aplicação e 
o solo foi gradeado e nivelado. Após um mês foi aplicado novamente o herbicida devido a uma nova infestação de braquiária e outras ervas daninhas (Figura 16).

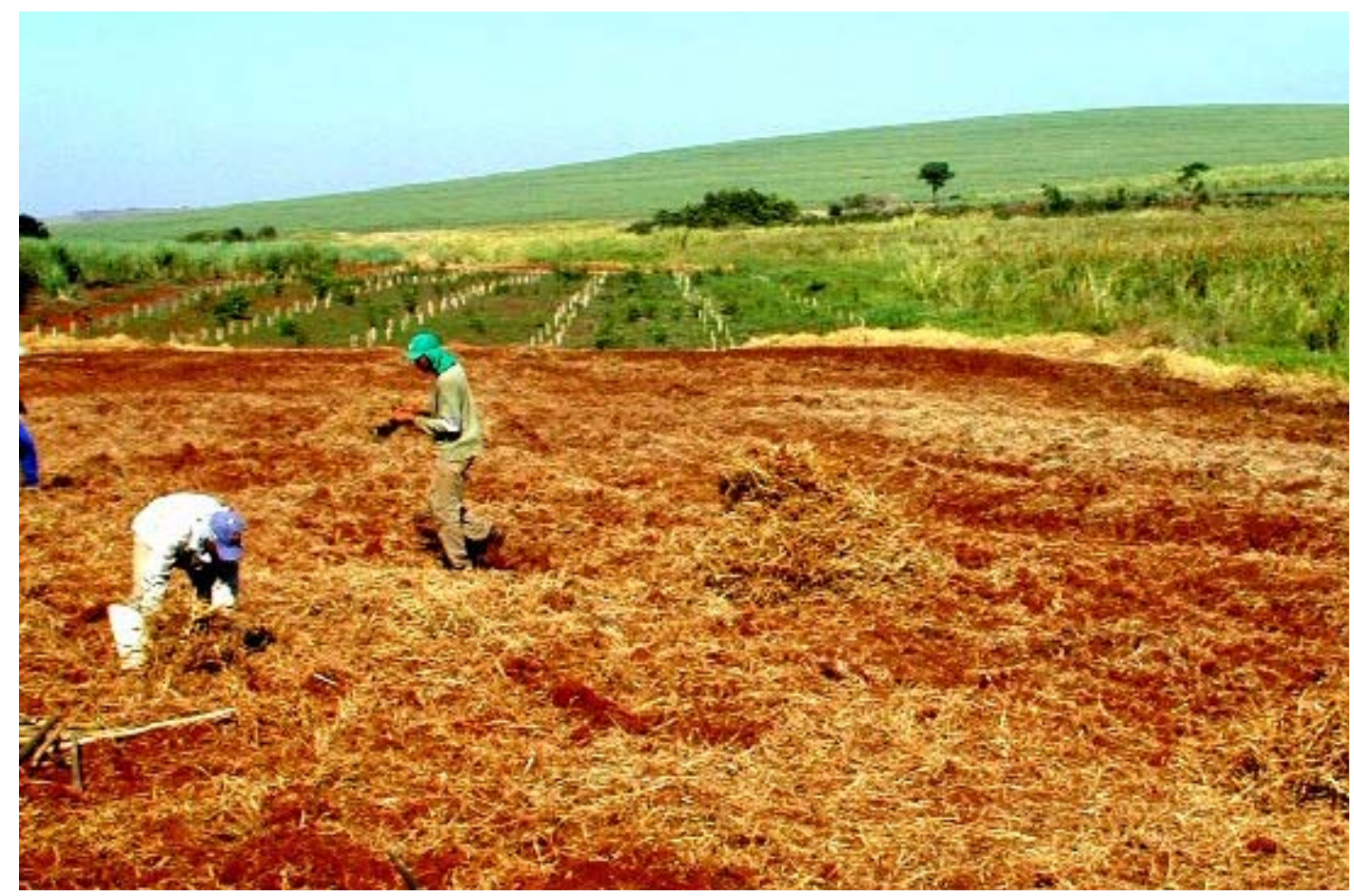

Figura 16 - Área do experimento "B" do projeto de semeadura direta sendo preparada para implantação, em destaque as parcelas do experimento "A" ao fundo. Fazenda Paineiras, Morro Agudo, SP

O herbicida pré-emergente utilizado foi à base de trifuralina $(600 \mathrm{~g} / \mathrm{l})$ numa proporção de 3 litros por hectare. O pré-emergente foi aplicado em novembro de 2003. Para a aplicação do produto, foi usada uma barra para pulverização aplicando-se $7,5 \mathrm{ml}$ em cada parcela com este tratamento (Figura 17). 


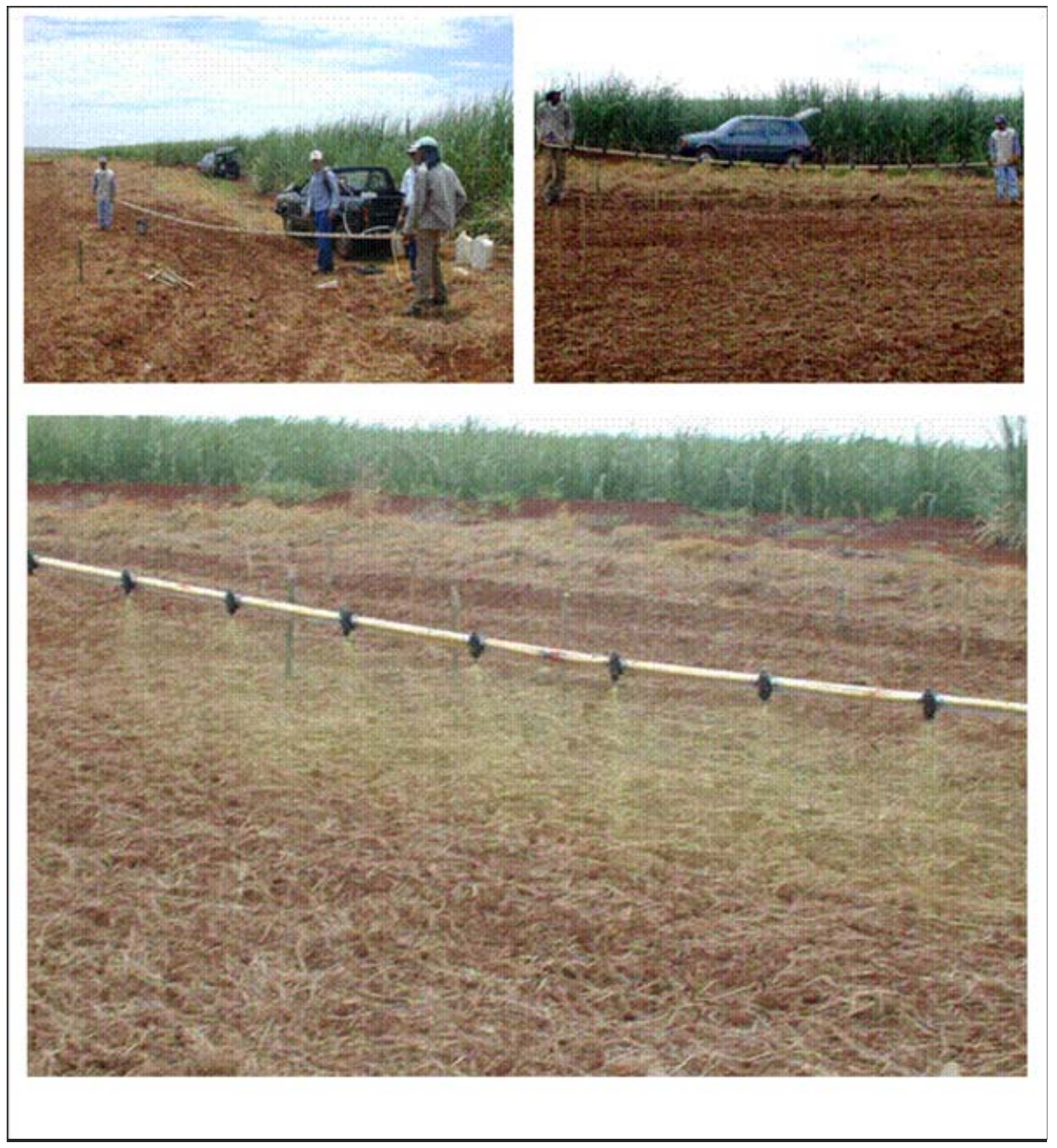

Figura 17 - Aplicação do herbicida pré-emergente nas parcelas do experimento "B", destacando-se a barra utilizada para a pulverização do produto, no projeto de semeadura direta. Fazenda Paineiras, Morro Agudo, SP

\subsubsection{Controle da germinação em sementeiras}

As sementes das espécies florestais nativas além de semeadas no campo tiveram também sua germinação testada em sementeiras no viveiro, para posterior comparação com a germinação das espécies em condições de campo. 
O experimento foi instalado na sementeira do viveiro de mudas nativas BioFlora, localizado no município de Piracicaba - SP. As sementes foram distribuídas em 4 sementeiras de $1 \times 1 \mathrm{~m}$ dividida em 20 baias de $5 \mathrm{~cm}$ separadas umas das outras por uma ripa de madeira (Figura 18). As sementeiras foram preparadas diretamente no solo usando areia peneirada com uma camada de aproximadamente $15 \mathrm{~cm}$ de espessura e uma camada de brita entre a areia e o solo. As condições de luminosidade foram de $40 \%$ (sombrite) com duas irrigações diárias realizadas pelo sistema de microaspersão.

Foram testadas 25 sementes por espécie (20 espécies, as mesmas utilizadas no experimento de campo, Anexo C) semeadas em linhas espaçadas $5 \mathrm{~cm}$ uma das outras e recobertas com uma fina camada de areia.

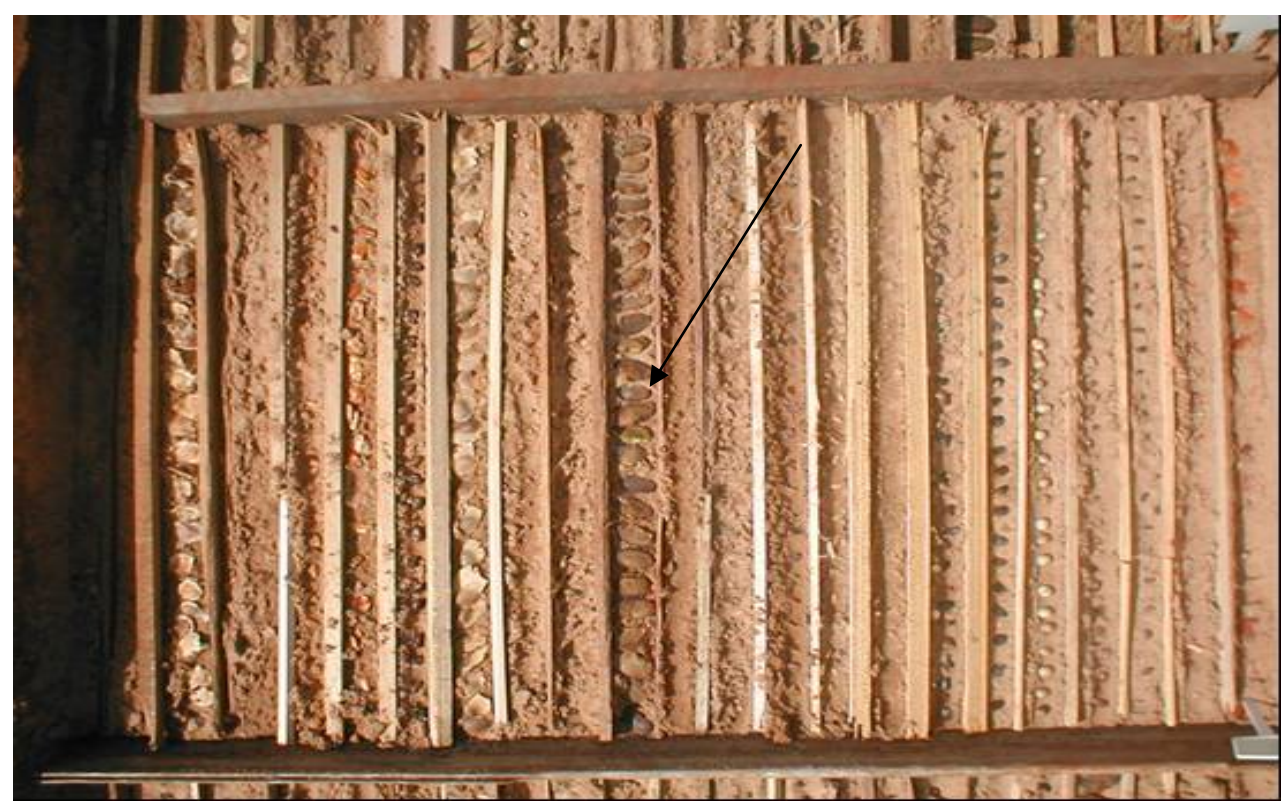

Figura 18 - Sementeira vista de cima com as sementes distribuídas, montada em viveiro para acompanhamento do experimento " $\mathrm{B}$ " do projeto de semeadura direta. Viveiro BioFlora, Piracicaba - SP 


\subsection{Avaliação da emergência e sobrevivência das espécies florestais}

\subsubsection{Experimento " $A$ "}

As coletas de dados do número de plantas estudadas no experimento "A", foram realizadas em 10 períodos, sendo aos 90, 120, 150, 180, 210, 240, 270, 300, 330, 360 dias após a semeadura (DAS) (um ano de avaliação póssemeadura). Porém para fins de análise estatística foram considerados os dados do primeiro (90 DAS) e último período (360 DAS).

Nas avaliações de número de plantas, todos os indivíduos foram contados dentro de cada parcela e identificados no campo. Aqueles que não puderam ser identificados foram classificados como morfo-espécie devido à insuficiência de material vegetativo até aquele momento sendo posteriormente identificados em avaliações futuras (Figuras 19, 20 e 21).

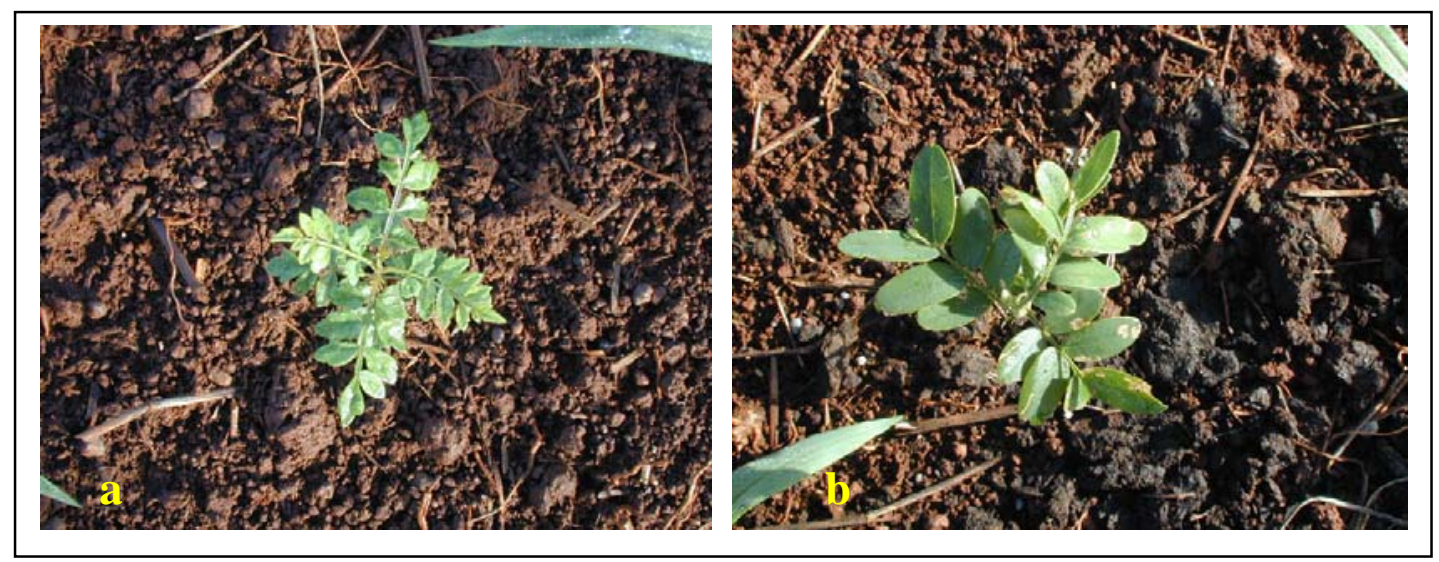

Figura 19 - Indivíduos emergentes (a) Jacaranda cuspidifolia Mart. e (b) Platypodium elegans Vog. vistos de cima na parcela do experimento " $A$ ", aos 90 dias após a semeadura no projeto de semeadura direta. Fazenda Paineiras, Morro Agudo, SP 


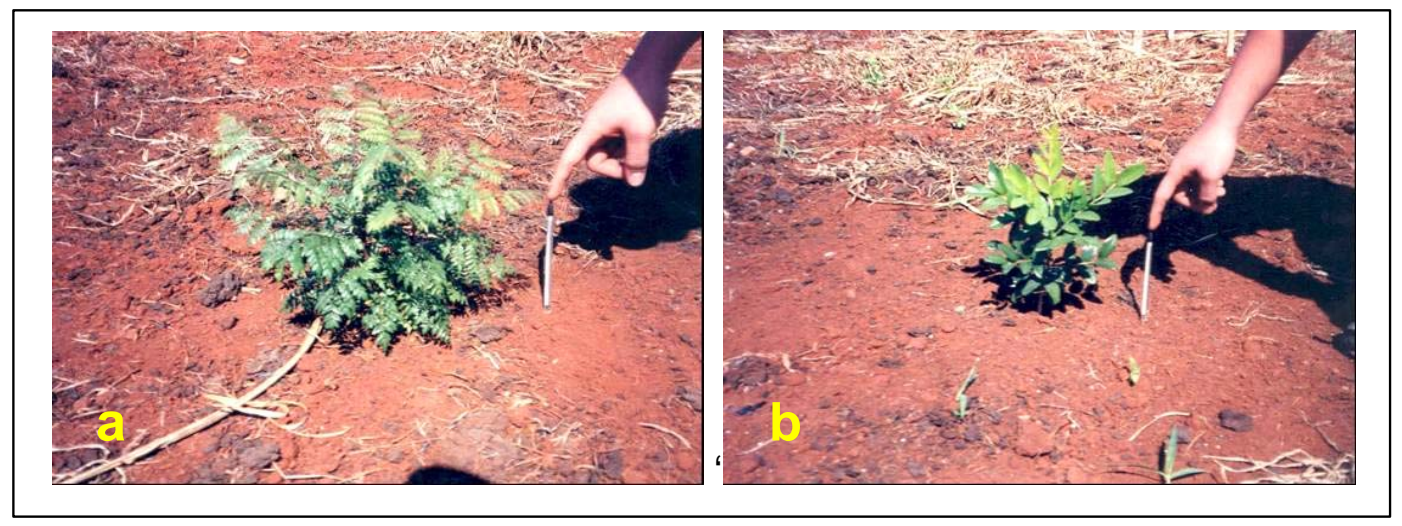

Figura 20 - Indivíduos emergentes (a) Jacaranda cuspidifolia Mart e (b) Pterogyne nitens Tul., na parcela do experimento "A" aos 120 dias após a semeadura, no projeto de semeadura direta. Fazenda Paineiras, Morro Agudo, SP

Ao final deste experimento, a normalidade dos dados de emergência das plântulas foi analisada utilizando-se o programa R. Através da análise exploratória de Box cox neste programa constatou-se a heterogeneidade de variância sugerindo transformação dos dados para $\sqrt{x}$. Assim os dados transformados (normalizados) foram tratados por meio da análise de variância e suas médias comparadas através do teste de Tukey a $5 \%$ de probabilidade, utilizando-se o programa ESTAT, obtido junto a UNESP de Jaboticabal. 


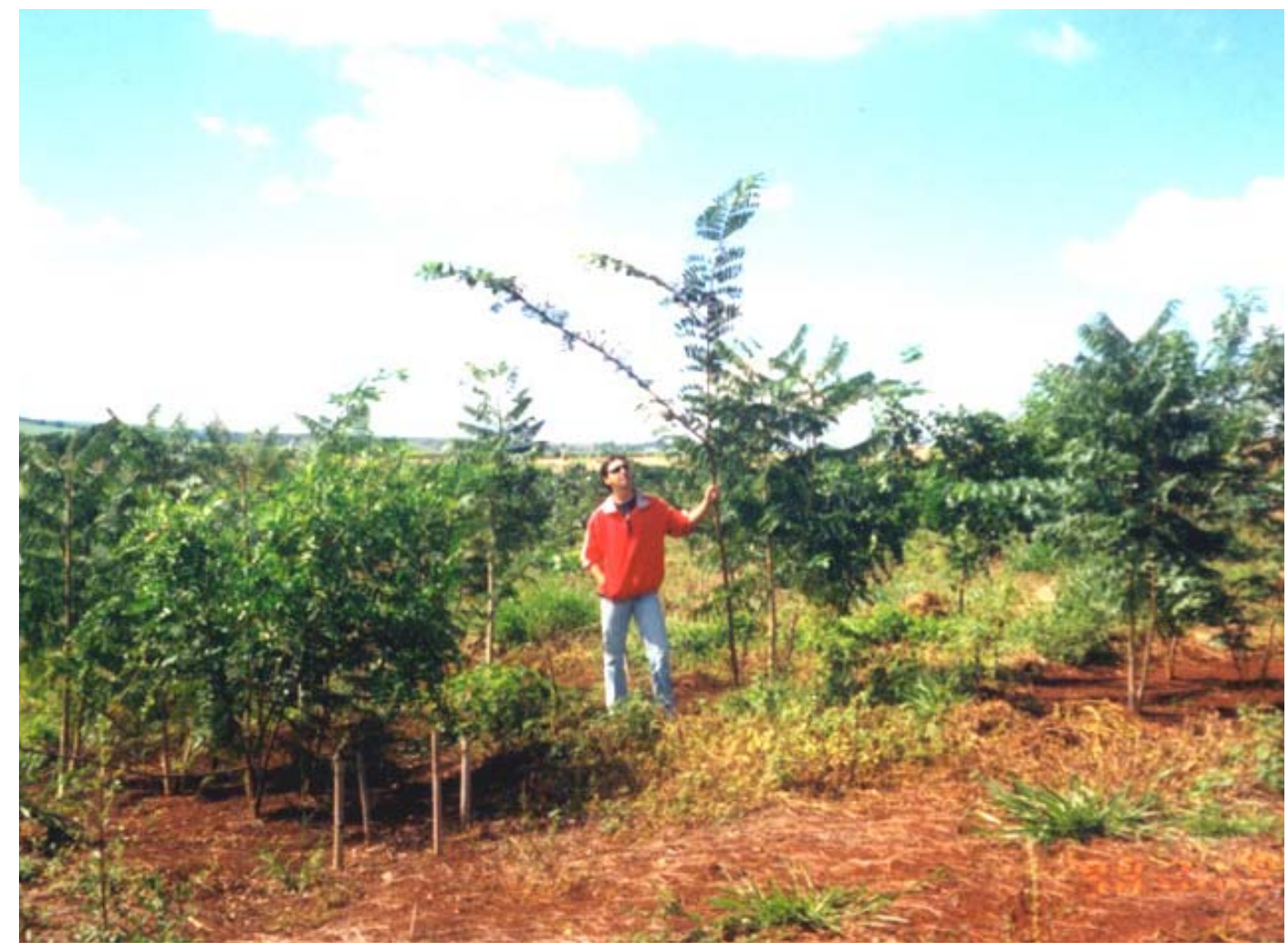

Figura 21 - Aspecto geral da área do experimento "A", um ano após a semeadura, no projeto de semeadura direta. Fazenda Paineiras, Morro Agudo, SP

\subsubsection{Experimento "B"}

\subsubsection{Experimento de campo e em viveiro}

Em ambos os experimentos (campo e viveiro) foram realizados somente avaliações quanto à emergência das espécies florestais semeadas, contando e identificando todos indivíduos emergidos.

Foram feitas seis avaliações concomitantes quinzenalmente após a semeadura (durante três meses pós-semeadura). 


\section{RESULTADOS E DISCUSSÃO}

\subsection{Experimento "A"}

Aqui serão apresentados e discutidos os resultados de emergência de plântulas das espécies estudadas aos 90 e 360 dias após a semeadura (DAS).

A população final destas será apresentada e discutida baseando-se na avaliação aos 360 DAS.

Embora o experimento tenha sido montado em esquema fatorial $3 \times 2 \times 3 \times 2$, para a análise de variância não foram considerados os valores das médias de porcentagem de emergência dos grupos (fator 1 com três níveis: pioneiras, pioneiras + secundárias e secundárias) devido a existência de extremas fontes de variações entre eles pelo fato das espécies neste grupo se comportarem diferentemente. Deste modo foram analisadas somente as porcentagens médias de emergência das espécies em cada grupo como experimento individual para preenchimento $(\mathbf{P})$, preenchimento + diversidade (P+D) e diversidade (D), assim o fatorial tornou-se $2 \times 3 \times 2$, sendo 12 tratamentos para cada espécie.

Foram consideradas neste experimento para o cálculo total de plantas por hectare todas as espécies que apresentavam no mínimo uma plântula (porcentagem média de 0,33) em uma das repetições (3 repetições). Porém para as análises estatísticas considerou-se somente aquelas com mais de uma plântula na média de emergência e que emergiram no mínimo seis tratamentos. 


\subsubsection{Emergência de plântulas}

Das 20 espécies florestais testadas (10 do grupo de preenchimento e 10 do grupo de diversidade) somente onze apresentaram emergência de plântulas aos 90 DAS em campo, sendo quatro delas pertencente ao grupo de preenchimento (Acacia polyphylla, Anadenanthera falcata, Platypodium elegans e Pterogyne nitens) e sete pertencente ao grupo de diversidade (Cedrella fissilis, Citharexyllum myrianthum, Croton floribundus, Dilodendron bipinnatum, Jacaranda cuspidifolia, Psidium guajava e Zanthoxylum rhoifolium), essas persistiram na área até os 360 DAS.

Das onze espécies emergidas, somente as do grupo de preenchimento $P$. elegans e $P$. nitens (nos grupos $P$ e $P+D$ ) e a do grupo de diversidade $J$. cuspidifolia (nos grupos D e P+D) apresentavam dados suficientes para a análise estatística.

As espécies do grupo de preenchimento $A$. polyphylla e $A$. falcata semeadas nos grupos $\mathrm{P}$ e $\mathrm{P}+\mathrm{D}$, e as grupo de diversidade $C$. fissilis, $C$. myrianthum, C. floribundus e Z. rhoifolium semeadas nos grupos D e P+D, apresentaram somente uma plântula emergida em uma das três repetições, portanto não foram incluídas nas análises estatísticas sendo somente incorporadas suas porcentagens de emergência na população final em cada grupo a que suas sementes foram semeadas.

A. polyphylla emergiu nos dois grupos $P$ e $P+D$ em que foi semeada, respectivamente nos tratamentos, sementes não peletizadas não incorporadas ao solo + matéria orgânica (M.O) + adubo e sementes não peletizadas incorporadas ao solo + M.O. A. falcata ocorreu somente no grupo $\mathrm{P}$ no tratamento: sementes não peletizadas incorporadas ao solo.

C. myrianthum emergiu em ambos os grupos em que foi semeada (D e $P+D)$, em dois tratamentos no grupo $D: 1$ ) sementes não peletizadas não incorporadas ao solo + M.O e 2) sementes peletizadas incorporadas ao solo e em dois tratamentos no grupo $\mathrm{P}+\mathrm{D}$ : 1) sementes não peletizadas incorporadas 
ao solo e 2) sementes não peletizadas + M.O + adubo. Para C. fissilis o tratamento onde houve emergência de plântulas em ambos os grupos ( $P$ e $P+D)$ foi: sementes não peletizadas incorporadas ao solo. C. floribundus e $Z$. rhoifolium apresentaram emergência somente no grupo $\mathrm{S}$, nos tratamentos respectivos, sementes não peletizadas incorporadas ao solo e sementes peletizadas incorporadas ao solo + M. O + adubo.

Para D. bipinnatum e $P$. guajava diferentemente das outras secundárias, apresentaram uma plântula na média entre os tratamentos que emergiram (uma plântula em cada uma das três repetições ou três plântulas em somente uma repetição). D. bipinnatum ocorreu somente no grupo $D$ nos seguintes tratamentos: sementes peletizadas incorporadas ao solo + M.O e sementes peletizadas incorporadas ao + M.O + adubo. Já $P$. guajava emergiu nos grupos $D$ e $P+D$, respectivamente nos tratamentos, sementes não peletizadas incorporadas ao solo e sementes peletizadas incorporadas ao solo + M.O + adubo. Essas duas espécies também não foram utilizadas nas análises estatísticas, porém suas porcentagens de emergência foram adicionadas na população total de cada grupo em que foram semeadas.

As espécies do grupo de preenchimento Albizia hasslerii, Bauhinia forficata, Casearia sylvestris, Cecropia pachystachya, Solanum erianthum e Trema micrantha e as do grupo de diversidade Genipa americana, Myracrodruon urundeuva e Ormosia arborea até os 360 DAS não apresentavam nenhuma plântula emergida nesse período.

O restante das espécies (3 espécies: Platypodium elegans, Pterogyne nitens e Jacaranda cuspidifolia), as quais apresentaram dados suficientes para análise estatística estão descritas a seguir com os valores de emergência de plântulas avaliados aos 90 DAS e 360 DAS para todas as condições testadas (condição da semente, substrato e incorporação), considerando as diferentes condições de combinações dos grupos funcionais (preenchimento e diversidade). 
As análise de variância para cada uma das três espécies emergidas nos grupos $P, P+D$ e D encontram-se em anexo (Anexo D ).

\subsubsection{População final}

Observa-se pela Tabela 4, que a população final aos 360 dias após a semeadura foi maior quando as espécies foram semeadas devidamente em seus grupos $D$ ou $P$ do que na mistura de todas juntas no grupo $P+D$. Tal fato afirma que a competição intra e interespecíficas das espécies são potencializadas quando se aumenta o número de plântulas na parcela.

Com base nos resultados apresentados na Tabela 4, considerando-se a média dos tratamentos utilizados da população final em relação à densidade inicial de sementes. Pode-se assegurar que o modelo empregado foi eficiente na forma como foi conduzido o experimento.

Tabela 4. População total das espécies florestais emergidas após 360 dias pós semeadura no experimento " $A$ " do projeto de semeadura direta ( $P=$ preenchimento, $\mathrm{D}=$ diversidade e $\mathrm{P}+\mathrm{D}=$ preenchimento + diversidade)

\begin{tabular}{cccc}
\hline Espécies/Grupos & P & D & P+D \\
\hline Platypodium elegans & 292 & & 259 \\
Pterogyne nitens & 318 & & 230 \\
$\begin{array}{c}\text { Jacaranda cuspidifolia } \\
\text { Outras espécies de } \\
\text { preenchimento (2) }\end{array}$ & 264 & 574 & 264 \\
$\begin{array}{c}\text { Outras espécies de } \\
\text { diversidade(6) }\end{array}$ & & & 132 \\
Totais (indivíduos/ha) & 874 & 1.328 & 532 \\
\hline
\end{tabular}


As outras espécies que foram incluídas na população final da Tabela 4 estão descritas no item anterior 4.1.1, bem como suas causas da não inclusão de seus dados nas análises estatísticas. As espécies que estão descritas na Tabela 4 como "outras espécies de preenchimento" são: $A$. polyphylla no grupo $\mathrm{P}$ e $\mathrm{P}+\mathrm{D}$ e $A$. falcata somente no grupo $\mathrm{P}$, com 132 indivíduos ha ${ }^{-1}$ para cada uma em cada grupo. As espécies descritas na Tabela 4 como "outras espécies de diversidade" são representadas por C. fissilis, C. floribundus e Z. rhoifolium, somente no grupo S e C. myrianthum, nos grupos D e $P+D$, com 132 ind./ha para cada uma das espécies em seus respectivos grupos. Ainda as espécies secundárias $D$. bipinnatum no grupo $D$ e $P$. guajava no grupo $D$ e $P+D$ representaram 400 ind./ha cada uma em seus grupos de ocorrência.

Nos modelos utilizados a partir do plantio de mudas à densidade varia de 1111 a 15.000 plantas/ha (Faria et al., 1994; Gandolfi \& Rodrigues, 1996; Pinã-Rodrigues et al., 1997; Barbosa, 2000; Davide et al., 2000).

Embora neste experimento tenha ocorrido uma baixa diversidade de espécies, o número de indivíduos por hectare é o suficiente para a ocupação de uma área desflorestada, em relação aos modelos propostos a partir de plantio de mudas como o de Botelho et al. (1995) que sugere uma combinação genérica, com $50 \%$ de espécies pioneiras, $40 \%$ de clímax exigentes de luz e $10 \%$ de clímax tolerantes à sombra. Barbosa (2000) sugere modelos de plantios utilizando 60\%, 30\% e 10\%, respectivamente, para pioneira, secundárias e clímax. Davide et al. (1994) utilizaram 50\% de Trema micrantha, mais 40\% de outras espécies de crescimento rápido e $10 \%$ de espécies de crescimento lento. Faria et al. (1994) utilizaram 50\% de espécies de crescimento rápido e 50\% de crescimento lento.

Rodrigues \& Gandolfi (2000) sugerem o enriquecimento de capoeiras e recomendam introduzir por semente ou muda nestes fragmentos, espécies que foram extintas localmente em função da degradação ou do processo sucessional em que se encontra o fragmento a ser recuperado. Esta seria uma alternativa futura na área deste experimento, visto que a área encontra-se 
recoberta, já fazendo o papel das espécies sombreadoras sugeridas pelos autores discutidos anteriormente. Neste processo, poderiam ser introduzidas espécies que Rodrigues et al. (2002) caracterizam como "diversidade" que são espécies não exigentes de luz e que na dinâmica sucessional viria a substituir estas pioneiras já estabelecidas na área experimental, ou "preenchimento" segundo os autores.

\subsubsection{Platypodium elegans}

Aos 90 DAS, com os dados apresentados na Tabela 5, foi verificado diferença significativa na emergência de plântulas de $P$. elegans no substrato onde as sementes foram semeadas com matéria orgânica e também quando incorporadas ao solo. Verificou-se que aos 360 DAS a única diferença significativa ocorreu quando às sementes foram incorporadas ao solo. Ambas as diferenças foram observadas quando as sementes de $P$. elegans foram semeadas no grupo $\mathrm{P}$ (Tabela 6). 
Tabela 5. Valores médios de porcentagem de emergência das plântulas da espécie Platypodium elegans estudada no grupo de preenchimento (P), aos 90 dias após a semeadura, nas diferentes condições testadas (NPel - sementes não peletizadas, Pel - sementes peletizadas, CIN - com incorporação da semente ao solo, SIN - sem incorporação da semente ao solo)

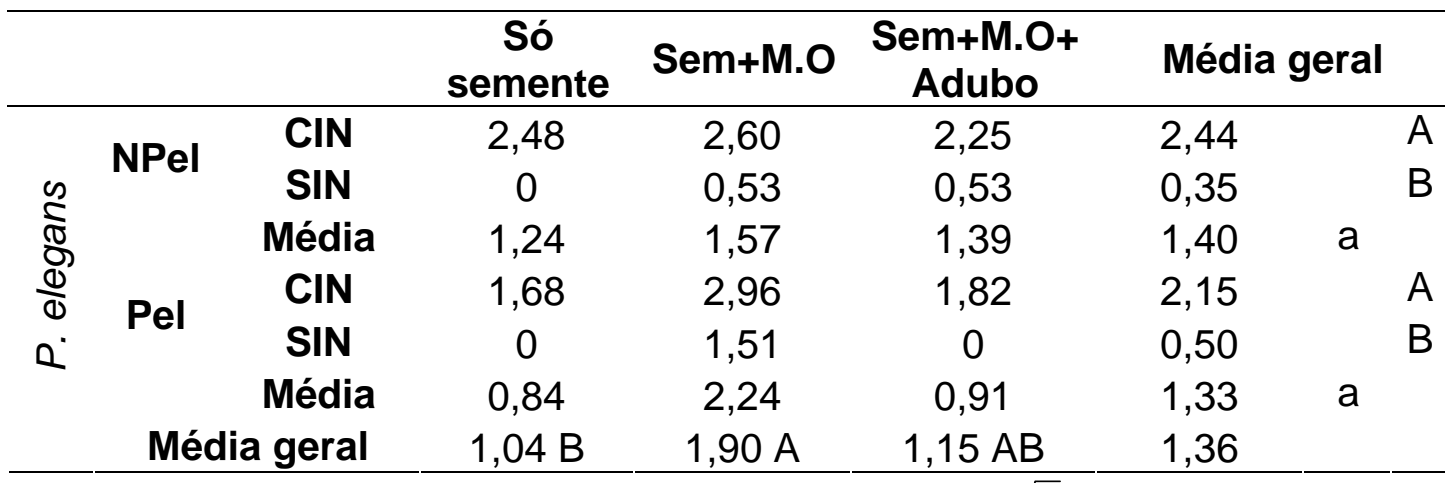

Obs.: Para análise estatística, os dados foram transformados em $\sqrt{x}$ e submetidos ao teste de Tukey.

Letras minúsculas na vertical comparam condição de sementes $\left(\Delta_{\text {Tukey }}=0,56\right)$

Letras maiúsculas na vertical comparam condição pós-semeadura, para cada condição de semente $\left(\Delta_{\text {Tukey }}=0,56\right)$

Letras maiúsculas na horizontal comparam os substratos $\left(\Delta_{\text {Tukey }}=0,83\right)$ 
Tabela 6. Valores médios de porcentagem de emergência das plântulas da espécie Platypodium elegans estudada no grupo de preenchimento $(\mathbf{P})$, aos $\mathbf{3 6 0}$ dias após a semeadura, nas diferentes condições testadas (NPel - sementes não peletizadas, Pel - sementes peletizadas, CIN - com incorporação da semente ao solo, SIN - sem incorporação da semente ao solo)

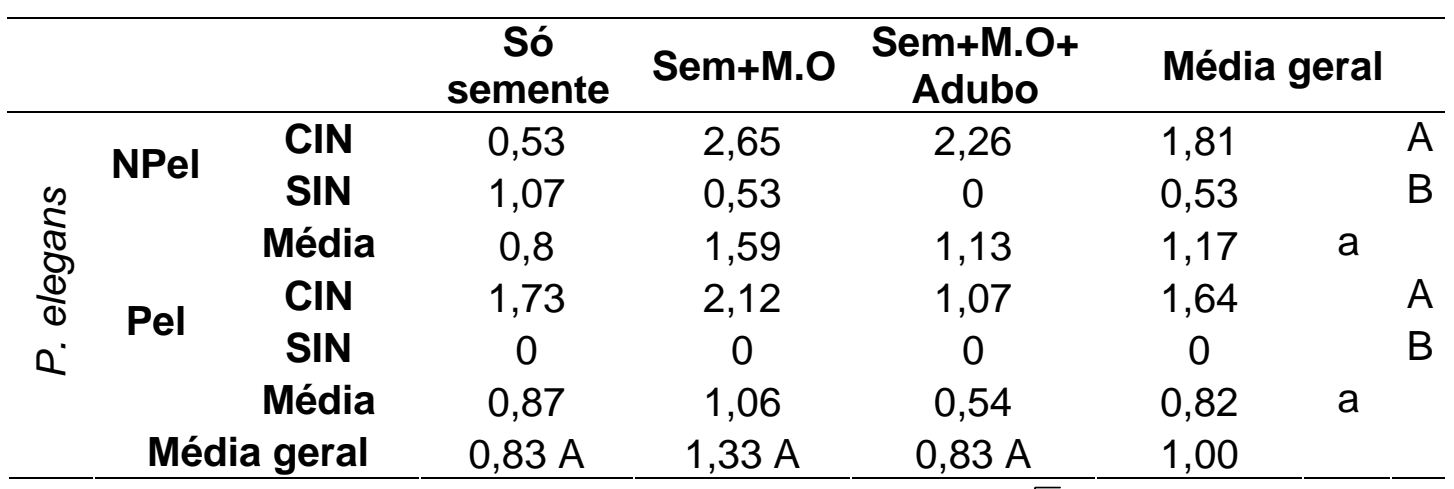

Obs.: Para análise estatística, os dados foram transformados em $\sqrt{x}$ e submetidos ao teste de Tukey.

Letras minúsculas na vertical comparam condição de sementes ( $\Delta_{\text {Tukey }}=0,67$ )

Letras maiúsculas na vertical comparam condição pós-semeadura, para cada condição de semente $\left(\Delta_{\text {Tukey }}=0,67\right)$

Letras maiúsculas na horizontal comparam os substratos $\left(\Delta_{\text {Tukey }}=1,00\right)$

Quando P. elegans foi semeada no grupo $P+D$ verificou-se efeito significativo somente com as sementes incorporadas ao solo, para os 90 DAS e 360 DAS (Tabela 7 e 8). 
Tabela 7. Valores médios de emergência das plântulas da espécie Platypodium elegans estudada no grupo preenchimento + diversidade (P+D), aos 90 dias após a semeadura, nas diferentes condições testadas (NPel - sementes não peletizadas, Pel - sementes peletizadas, CIN - com incorporação da semente ao solo, SIN - sem incorporação da semente ao solo)

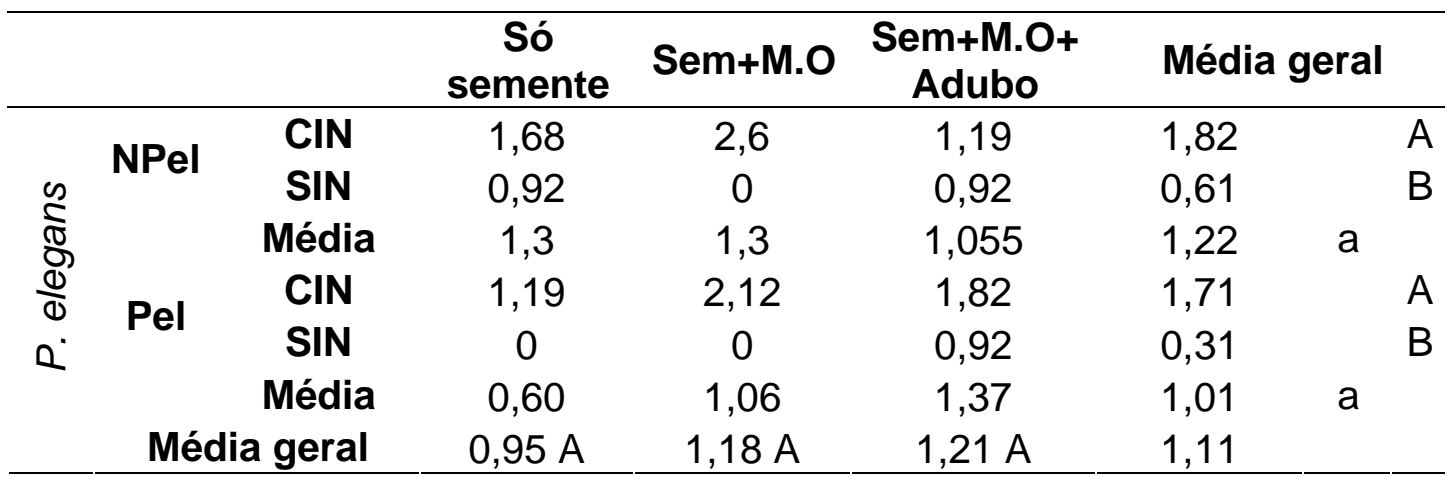

Obs.: Para análise estatística, os dados foram transformados em $\sqrt{x}$ e submetidos ao teste de Tukey.

Letras minúsculas na vertical comparam condição de sementes $\left(\Delta_{\text {Tukey }}=0,96\right)$

Letras maiúsculas na vertical comparam condição pós-semeadura, para cada condição de semente $\left(\Delta_{\text {Tukey }}=0,96\right)$

Letras maiúsculas na horizontal comparam os substratos $\left(\Delta_{\text {Tukey }}=1,42\right)$ 
Tabela 8. Valores médios de emergência das plântulas da espécie estudada Platypodium elegans no grupo preenchimento + diversidade (P+D), aos $\mathbf{3 6 0}$ dias após a semeadura, nas diferentes condições testadas (NPel - sementes não peletizadas, Pel - sementes peletizadas, CIN - com incorporação da semente ao solo, SIN - sem incorporação da semente ao solo)

\begin{tabular}{|c|c|c|c|c|c|c|c|c|}
\hline & & & $\begin{array}{c}\text { Só } \\
\text { semente }\end{array}$ & Sem+M.O & $\begin{array}{c}\text { Sem+M.O+ } \\
\text { Adubo }\end{array}$ & Médi & ral & \\
\hline & & CIN & 1,29 & 2,6 & 1,07 & 1,65 & & $\bar{A}$ \\
\hline 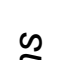 & NPel & SIN & 0,53 & 0,53 & 1,29 & 0,78 & & $B$ \\
\hline$\frac{\widetilde{\pi}}{\sigma}$ & & Média & 0,91 & 1,57 & 1,18 & 1,22 & $\mathrm{a}$ & \\
\hline$\frac{d}{d}$ & Pel & CIN & 1,99 & 1,29 & 1,6 & 1,63 & & A \\
\hline $0^{\circ}$ & Pel & SIN & 0 & 0 & 0 & 0 & & $B$ \\
\hline & & Média & 1,00 & 0,65 & 0,80 & 0,81 & $\mathrm{a}$ & \\
\hline & Mé & geral & $0,95 \mathrm{~A}$ & $1,11 \mathrm{~A}$ & $0,99 \mathrm{~A}$ & 1,02 & & \\
\hline
\end{tabular}

Obs.: Para análise estatística, os dados foram transformados em $\sqrt{x}$ e submetidos ao teste de Tukey.

Letras minúsculas na vertical comparam condição de sementes $\left(\Delta_{\text {Tukey }}=0,62\right)$

Letras maiúsculas na vertical comparam condição pós-semeadura, para cada condição de semente $\left(\Delta_{\text {Tukey }}=0,62\right)$

Letras maiúsculas na horizontal comparam os substratos $\left(\Delta_{\text {Tukey }}=0,92\right)$

Os dados sugerem que as sementes de $P$. elegans, quando incorporadas ao solo reduzem significantemente as taxas de predação (por insetos, aves, roedores, entre outros), além de uma maior disponibilidade hídrica na semente nessa condição de incorporação. Há também evidências de que a ação da luz solar direta afetou negativamente a germinação desta espécie pelo dessecamento das sementes. Tais fatos já foram comprovados pelos trabalhos com semeadura direta como os de Sun \& Dickinson (1995) na Austrália, Ammer et al. (2002) na Alemanha, Nilson \& Hjältén (2003) na Suécia e Woods \& Elliott (2004) no norte da Tailândia.

Acredita-se também que o uso de matéria orgânica (esterco bovino) contribuiu com a manutenção de maior umidade do solo, formando um microssítio favorável à germinação da semente. 
A porcentagem média de emergência de plântulas para $P$. elegans no grupo $\mathrm{P}$ entre os tratamentos aos 90 DAS em relação ao número de sementes semeadas inicialmente (39 sementes por parcela) foi de 2,98 o que representa 464 indivíduos ha ${ }^{-1}$. Aos 360 DAS a porcentagem média dos indivíduos estabelecidos foi de 1,87 ou 292 indivíduos ha ${ }^{-1}$. Houve neste período uma perda das plântulas emergidas de 37,06\% em relação à primeira avaliação aos 90 DAS quando $P$. elegans foi combinado com outras espécies do grupo de preenchimento (Figura 22).

$P$. elegans no grupo $\mathrm{P}+\mathrm{D}$ entre os tratamentos obteve uma porcentagem média de emergência aos 90 DAS de 1,90 ou 297 indivíduos ha ${ }^{-1}$. Aos 360 DAS a porcentagem média de indivíduos estabelecidos era de 1,66 o mesmo que 259 indivíduos ha ${ }^{-1}$. Este valor representa uma perda de 12,79\% das plântulas emergidas comparando com a porcentagem de emergência da primeira avaliação (90 DAS), quando $P$. elegans foi combinado com outras espécies do grupo de preenchimento e diversidade (Figura 22).

A diferença de emergência de plântulas de $P$. elegans entre os grupos $P$ e $P+D$ aos 90 DAS foi de 36\%. Já a diferença da população final (360 DAS) entre os grupos foi de $11,3 \%$. Por estes resultados, $P$. elegans demonstra sofrer influência da interação com outras espécies quando semeadas no grupo de preenchimento e diversidade $(P+D)$. Deste modo, $P$. elegans por estar sob condição de um número maior de sementes, apresenta menor capacidade competitiva no processo pós-germinativo. 


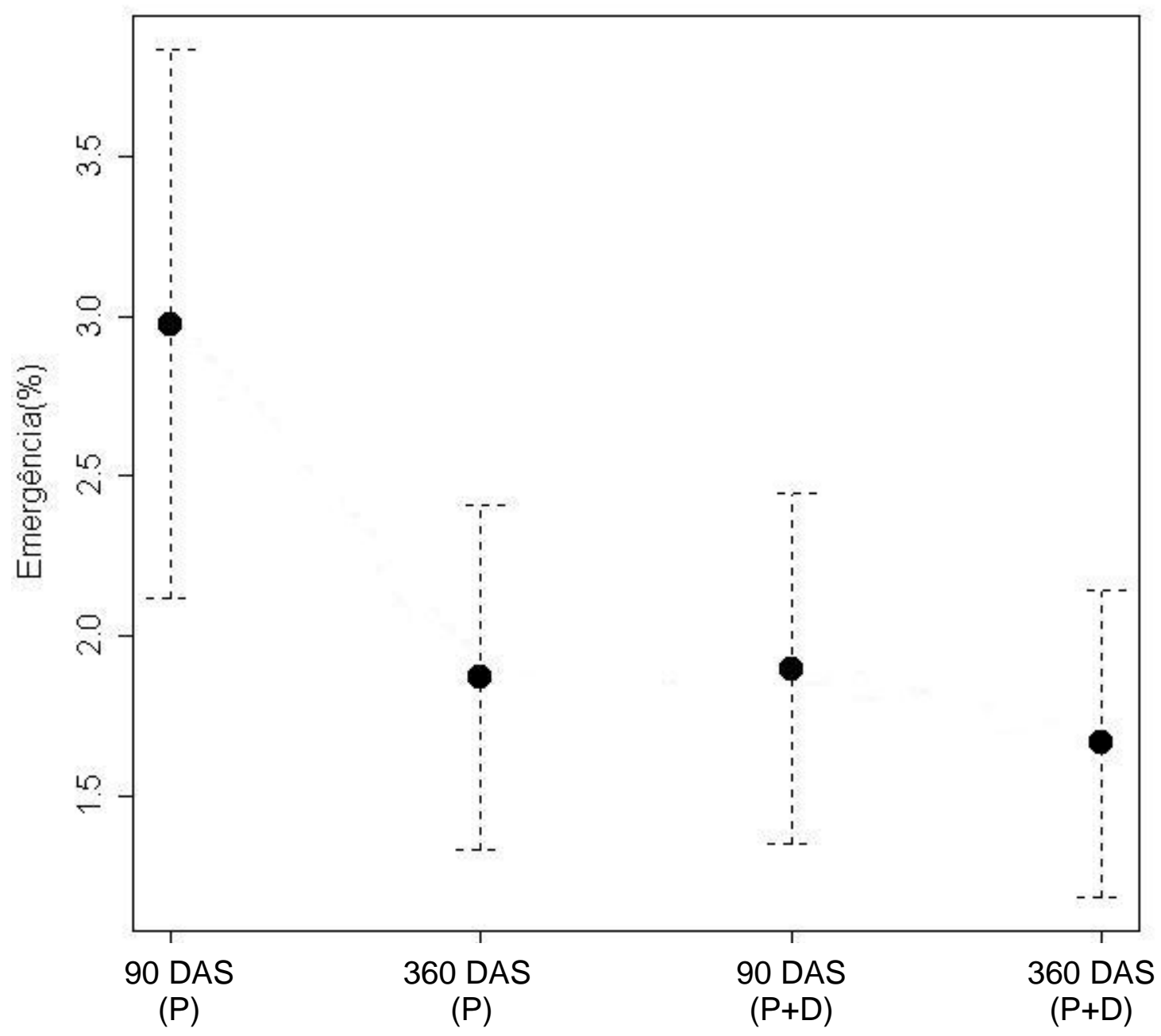

Figura 22 - Médias de porcentagens de emergência e erro padrão para $P$. elegans no grupo $P$ (preenchimento), no grupo $P+D$ (preenchimento e diversidade) aos 90 e 360 dias após a semeadura (DAS) do experimento "A" do projeto de semeadura direta 


\subsubsection{Pterogyne nitens}

A emergência de plântulas de $P$. nitens de acordo com os dados apresentados na Tabela 9 e 10 demonstrou ser indiferente aos tratamentos a que foi submetida aos 90 DAS e 360 DAS. Já quando semeada no grupo P+D de acordo com os dados da Tabela 11 aos 90 DAS verificou-se diferença significativa para emergência de plântulas com uso de sementes não peletizadas. Aos 360 DAS como apresentados na Tabela 12, no grupo P+D observa-se que as sementes incorporadas ao solo foram significantes na emergência de plântulas fato já discutido no item anterior para P.elegans em ambos os períodos (90 e 360 DAS) e grupos (P e P+D).

Tabela 9. Valores médios de porcentagem de emergência das plântulas da espécie Pterogyne nitens estudada no grupo de preenchimento (P), aos 90 dias após a semeadura, nas diferentes condições testadas (NPel - sementes não peletizadas, Pel - sementes peletizadas, CIN - com incorporação da semente ao solo, SIN - sem incorporação da semente ao solo)

\begin{tabular}{|c|c|c|c|c|c|c|c|c|}
\hline & & & $\begin{array}{c}\text { Só } \\
\text { semente }\end{array}$ & Sem+M.O & $\begin{array}{c}\text { Sem+M.O+ } \\
\text { Adubo }\end{array}$ & Médi & eral & \\
\hline & NPel & CIN & 1,05 & 2,33 & 1,72 & 1,70 & & $A$ \\
\hline & INPeI & SIN & 0 & 2,08 & 0 & 0,69 & & A \\
\hline ฮ & & Média & 0,525 & 2,21 & 0,86 & 1,20 & $\mathrm{a}$ & \\
\hline 芯 & Dol & CIN & 2,1 & 2,07 & 1,47 & 1,88 & & A \\
\hline $0^{\circ}$ & rei & SIN & 1,82 & 2,07 & 1,66 & 1,85 & & A \\
\hline & & Média & 1,96 & 2,07 & 1,57 & 1,87 & $\mathrm{a}$ & \\
\hline & Mé & a geral & $1,24 \mathrm{~A}$ & $2,14 \mathrm{~A}$ & $1,21 \mathrm{~A}$ & 1,53 & & \\
\hline
\end{tabular}

Obs.: Para análise estatística, os dados foram transformados em $\sqrt{x}$ e submetidos ao teste de Tukey.

Letras minúsculas na vertical comparam condição de sementes ( $\Delta_{\text {Tukey }}=0,81$ )

Letras maiúsculas na vertical comparam condição pós-semeadura, para cada condição de semente $\left(\Delta_{\text {Tukey }}=0,81\right)$

Letras maiúsculas na horizontal comparam os substratos $\left(\Delta_{\text {Tukey }}=1,20\right)$ 
Tabela 10. Valores médios de porcentagem de emergência das plântulas da espécie Pterogyne nitens estudada no grupo de preenchimento $(\mathbf{P})$, aos 360 dias após a semeadura, nas diferentes condições testadas (NPel - sementes não peletizadas, Pel - sementes peletizadas, CIN - com incorporação da semente ao solo, SIN - sem incorporação da semente ao solo)

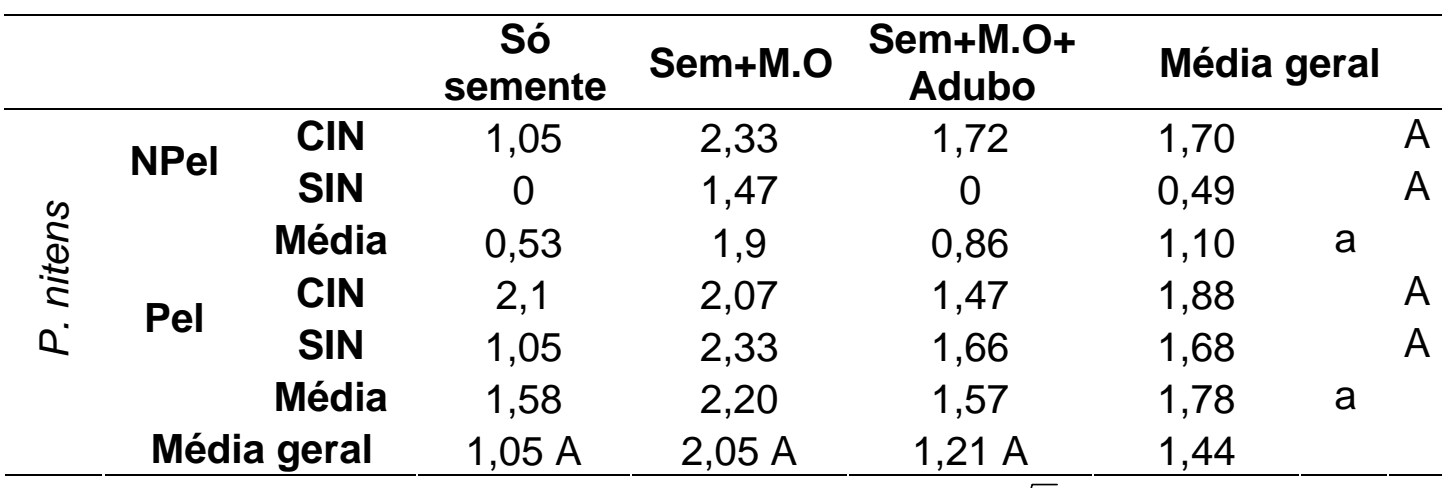

Obs.: Para análise estatística, os dados foram transformados em $\sqrt{x}$ e submetidos ao teste de Tukey.

Letras minúsculas na vertical comparam condição de sementes $\left(\Delta_{\text {Tukey }}=0,85\right)$

Letras maiúsculas na vertical comparam condição pós-semeadura, para cada condição de semente $\left(\Delta_{\text {Tukey }}=0,85\right)$

Letras maiúsculas na horizontal comparam os substratos $\left(\Delta_{\text {Tukey }}=1,26\right)$ 
Tabela 11. Valores médios de emergência das plântulas da espécie Pterogyne nitens estudada no grupo preenchimento + diversidade $(\mathbf{P}+\mathbf{D})$, aos 90 dias após a semeadura, nas diferentes condições testadas (NPel - sementes não peletizadas, Pel - sementes peletizadas, CIN - com incorporação da semente ao solo, SIN - sem incorporação da semente ao solo)

\begin{tabular}{|c|c|c|c|c|c|c|c|c|}
\hline & & & $\begin{array}{c}\text { Só } \\
\text { semente }\end{array}$ & Sem+M.O & $\begin{array}{c}\text { Sem+M.O+ } \\
\text { Adubo }\end{array}$ & Médi & eral & \\
\hline \multirow{7}{*}{ 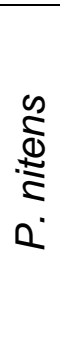 } & \multirow{2}{*}{ NPel } & CIN & 3,08 & 1,72 & 1,66 & 2,15 & & $A$ \\
\hline & & SIN & 1,22 & 1,05 & 1,82 & 1,36 & & A \\
\hline & \multirow{4}{*}{ Pel } & Média & 2,15 & 1,39 & 1,74 & 1,76 & $\mathrm{a}$ & \\
\hline & & CIN & 1,05 & 1,05 & 1,05 & 1,05 & & $A$ \\
\hline & & SIN & 1,05 & 0 & 0 & 0,35 & & $A$ \\
\hline & & Média & 1,05 & 0,53 & 0,53 & 0,70 & $b$ & \\
\hline & \multicolumn{2}{|c|}{ Média geral } & $1,60 \mathrm{~A}$ & $0,96 \mathrm{~A}$ & $1,13 \mathrm{~A}$ & 1,23 & & \\
\hline
\end{tabular}

Obs.: Para análise estatística, os dados foram transformados em $\sqrt{x}$ e submetidos ao teste de Tukey.

Letras minúsculas na vertical comparam condição de sementes $\left(\Delta_{\text {Tukey }}=1,05\right)$

Letras maiúsculas na vertical comparam condição pós-semeadura, para cada condição de semente $\left(\Delta_{\text {Tukey }}=1,05\right)$

Letras maiúsculas na horizontal comparam os substratos $\left(\Delta_{\text {Tukey }}=1,56\right)$ 
Tabela 12. Valores médios de emergência das plântulas da espécie estudada, Pterogyne nitens no grupo preenchimento + diversidade (P+D), aos 360 dias após a semeadura, nas diferentes condições testadas (NPel - sementes não peletizadas, Pel - sementes peletizadas, CIN - com incorporação da semente ao solo, SIN - sem incorporação da semente ao solo)

\begin{tabular}{|c|c|c|c|c|c|c|c|c|}
\hline & & & $\begin{array}{c}\text { Só } \\
\text { semente }\end{array}$ & Sem+M.O & $\begin{array}{c}\text { Sem+M.O+ } \\
\text { Adubo }\end{array}$ & Médi & eral & \\
\hline \multirow{7}{*}{ 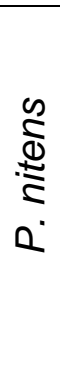 } & \multirow{2}{*}{ NPel } & CIN & 2,84 & 1,47 & 1,47 & 1,93 & & A \\
\hline & & SIN & 1,36 & 1,47 & 1,66 & 1,50 & & B \\
\hline & \multirow{4}{*}{ Pel } & Média & 2,10 & 1,47 & 1,57 & 1,71 & $\mathrm{a}$ & \\
\hline & & CIN & 0 & 1,66 & 0 & 0,55 & & $A$ \\
\hline & & SIN & 0,86 & 0,61 & 0 & 0,49 & & B \\
\hline & & Média & 0,43 & 1,14 & 0 & 0,52 & $\mathrm{a}$ & \\
\hline & \multicolumn{2}{|c|}{ Média geral } & $1,27 \mathrm{~A}$ & $1,30 \mathrm{~A}$ & $0,78 \mathrm{~A}$ & 1,12 & & \\
\hline
\end{tabular}

Obs.: Para análise estatística, os dados foram transformados em $\sqrt{x}$ e submetidos ao teste de Tukey.

Letras minúsculas na vertical comparam condição de sementes $\left(\Delta_{\text {Tukey }}=0,89\right)$

Letras maiúsculas na vertical comparam condição pós-semeadura, para cada condição de semente $\left(\Delta_{\text {Tukey }}=0,, 89\right)$

Letras maiúsculas na horizontal comparam os substratos $\left(\Delta_{\text {Tukey }}=1,32\right)$

Foi observado em campo que as sementes peletizadas com gel hidrofílico na maioria das vezes apresentavam visualmente a formação de fungos no pélete. Outra questão a ser levantada é que na indisponibilidade de água logo após a germinação da semente, o gel poderia estar fazendo o papel contrário a que foi submetido, ou seja, ao invés de reter a água que auxiliaria no desenvolvimento da plântula, este estaria "retirando" a água da semente germinada. Isto dificulta qualquer tipo de conclusão por estas variáveis acima apresentadas não terem sido mensuradas. Outro fator relevante é que a condição da semente peletizada teve efeito negativo somente na espécie $P$. nitens somente quando semeada no grupo $\mathrm{P}+\mathrm{D}$ e aos 90 DAS não tendo ocorrido aos 360 DAS e em nenhum período no grupo $P$. 
A porcentagem média de emergência de plântulas para $P$. nitens no grupo $P$ entre os tratamentos aos 90 DAS em relação ao número de sementes semeadas (30 sementes por parcela) foi de 2,92 o que representa 350 indivíduos ha ${ }^{-1}$. Aos 360 DAS a média de emergência foi de 2,65 ou 318 indivíduos ha ${ }^{-1}$. Houve neste período uma perda das plântulas emergidas de $9,14 \%$ em relação à primeira avaliação aos 90 DAS quando $P$. nitens foi combinado com outras espécies do grupo de preenchimento (Figura 23).

$P$. nitens no grupo $P+D$ entre os tratamentos teve uma porcentagem média de emergência aos 90 DAS de 2,13 ou 256 indivíduos ha ${ }^{-1}$. Aos 360 DAS a porcentagem de indivíduos estabelecidos era de 1,92 o mesmo que 230 indivíduos ha ${ }^{-1}$. Este valor representa uma perda das plântulas emergidas de $10,15 \%$ em relação à primeira avaliação aos 90 DAS quando $P$. nitens foi combinado com outras espécies do grupo de preenchimento e diversidade (Figura 23).

A diferença de emergência de plântulas de $P$. nitens entre os grupos $P$ e P+D aos 90 DAS foi de 26,85\%. Já a diferença da população final (360 DAS) entre os grupos $\mathrm{P}$ e P+D foi de $26,67 \%$. Destaca-se que a maior porcentagem de emergência ocorreu no grupo $P$. Por estes resultados, $P$. elegans demonstra sofrer influência da interação com outras espécies quando semeadas no grupo de preenchimento e diversidade $(P+D)$. Deste modo, $P$. nitens semelhantemente a $P$. elegans, por também estar sob condição de um número maior de sementes, apresenta menor capacidade competitiva no processo pós-germinativo. 


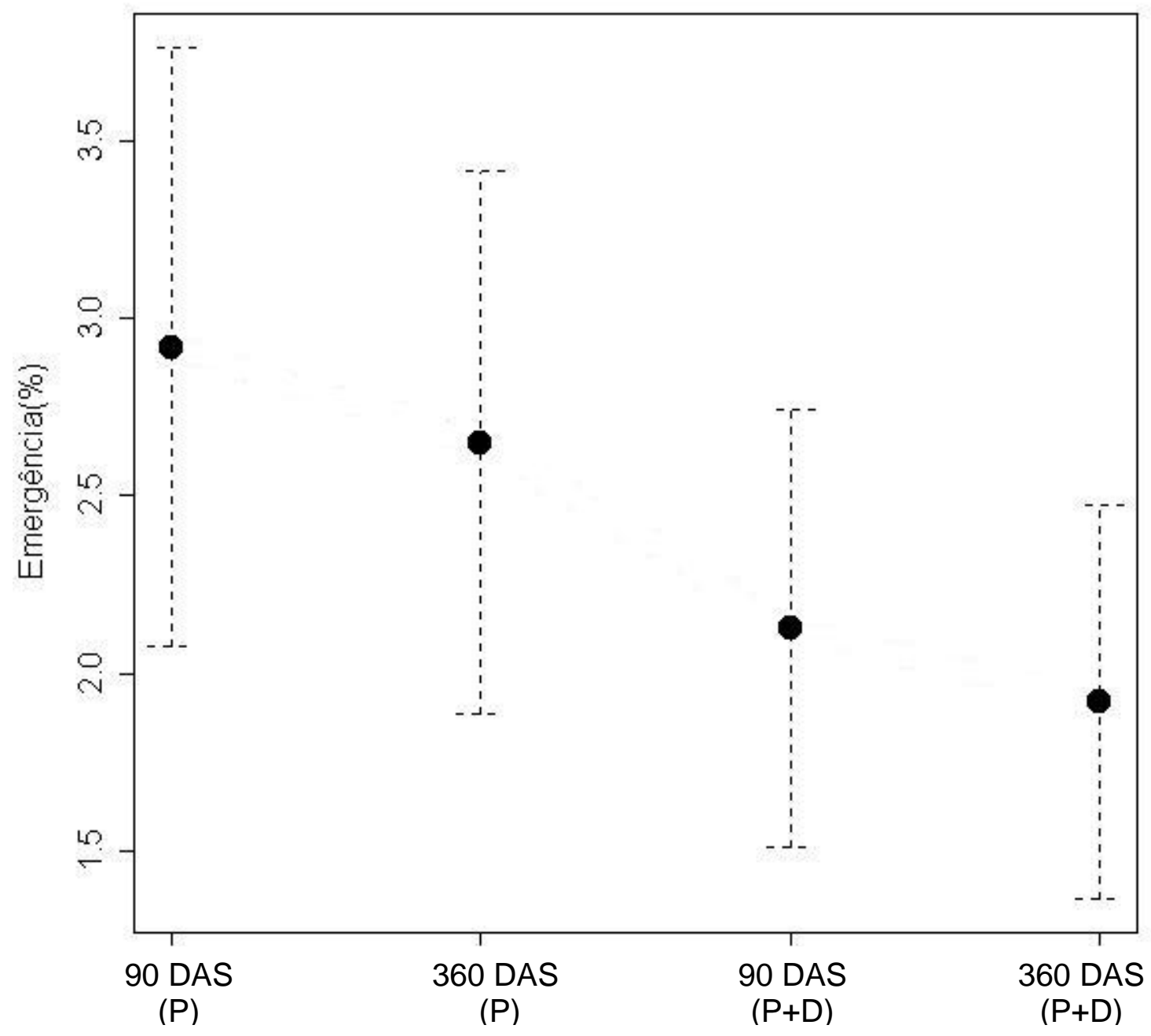

Figura 23 - Médias de porcentagens de emergência para $P$. nitens no grupo $P$ (preenchimento) e no grupo P+D (preenchimento e diversidade) aos 90 e 360 dias após a semeadura (DAS) do experimento "A" do projeto de semeadura direta

\subsubsection{Jacaranda cuspidifolia}

J. cuspidifolia quando semeada no grupo D aos 90 DAS demonstrou ser indiferente aos tratamentos a que foram submetidos (Tabela 13). Já aos 360 
DAS no grupo D a diferença significativa para emergência de plântulas novamente é encontrada na incorporação das sementes ao solo já discutida para a espécie $P$. elegans (Tabela 14). Somente o uso de sementes incorporadas ao solo demonstrou também para esta espécie ser eficiente na emergência de plântulas aos 90 e 360 DAS quando semeada no grupo $P+D$ (Tabelas 15 e 16).

Tabela 13. Valores médios de emergência das plântulas da espécie Jacaranda cuspidifolia estudada no grupo de diversidade (D), aos $\mathbf{9 0}$ dias após a semeadura, nas diferentes condições testadas (NPel - sementes não peletizadas, Pel - sementes peletizadas, CIN - com incorporação da semente ao solo, SIN - sem incorporação da semente ao solo)

\begin{tabular}{|c|c|c|c|c|c|c|c|c|}
\hline & & & $\begin{array}{c}\text { Só } \\
\text { semente }\end{array}$ & Sem+M.O & $\begin{array}{c}\text { Sem+M.O+ } \\
\text { Adubo }\end{array}$ & Médi & eral & \\
\hline \multirow{5}{*}{$\begin{array}{l}\frac{\pi}{\overline{0}} \\
\frac{0}{2} \\
\frac{0}{2} \\
\frac{0}{0} \\
0\end{array}$} & \multirow{2}{*}{ NPel } & CIN & 2,39 & 1,05 & 1,05 & 1,50 & & $\bar{A}$ \\
\hline & & SIN & 1,47 & 1,05 & 1,05 & 1,19 & & $A$ \\
\hline & \multirow{3}{*}{ Pel } & Média & 1,93 & 1,05 & 1,05 & 1,34 & $a$ & \\
\hline & & CIN & 2,18 & 2,22 & 1,05 & 1,82 & & $A$ \\
\hline & & SIN & 1,05 & 1,05 & 1,66 & 1,25 & & $A$ \\
\hline \multirow[t]{2}{*}{$i$} & & Média & 1,62 & 1,64 & 1,36 & 1,54 & $\mathrm{a}$ & \\
\hline & \multicolumn{2}{|c|}{ Média geral } & $1,77 \mathrm{~A}$ & $1,34 \mathrm{~A}$ & $1,20 \mathrm{~A}$ & 1,44 & & \\
\hline
\end{tabular}

Obs.: Para análise estatística, os dados foram transformados em $\sqrt{x}$ e submetidos ao teste de Tukey.

Letras minúsculas na vertical comparam condição de sementes $\left(\Delta_{\text {Tukey }}=1,34\right)$

Letras maiúsculas na vertical comparam condição pós-semeadura, para cada condição de semente $\left(\Delta_{\text {Tukey }}=1,34\right)$

Letras maiúsculas na horizontal comparam os substratos $\left(\Delta_{\text {Tukey }}=1,99\right)$ 
Tabela 14. Valores médios de emergência das plântulas da espécie estudada Jacaranda cuspidifolia no grupo de diversidade (D), aos 360 dias após a semeadura, nas diferentes condições testadas (NPel sementes não peletizadas, Pel - sementes peletizadas, CIN - com incorporação da semente ao solo, SIN - sem incorporação da semente ao solo)

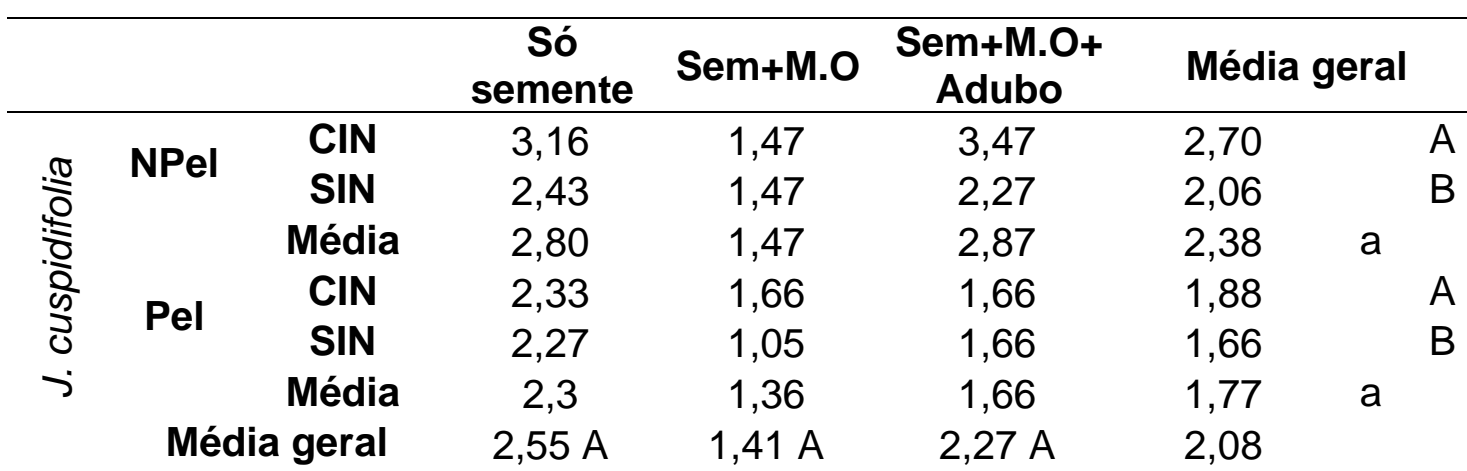

Obs.: Para análise estatística, os dados foram transformados em $\sqrt{x}$ e submetidos ao teste de Tukey.

Letras minúsculas na vertical comparam condição de sementes $\left(\Delta_{\text {Tukey }}=0,81\right)$

Letras maiúsculas na vertical comparam condição pós-semeadura, para cada condição de semente $\left(\Delta_{\text {Tukey }}=0,81\right)$

Letras maiúsculas na horizontal comparam os substratos $\left(\Delta_{\text {Tukey }}=1,21\right)$ 
Tabela 15. Valores médios de emergência das plântulas da espécie Jacaranda cuspidifolia estudada no grupo preenchimento + diversidade (P+D), aos 90 dias após a semeadura, nas diferentes condições testadas (NPel - sementes não peletizadas, Pel - sementes peletizadas, CIN - com incorporação da semente ao solo, SIN - sem incorporação da semente ao solo)

\begin{tabular}{|c|c|c|c|c|c|c|c|c|}
\hline & & & $\begin{array}{c}\text { Só } \\
\text { semente }\end{array}$ & Sem+M.O & $\begin{array}{c}\text { Sem+M.O+ } \\
\text { Adubo }\end{array}$ & Médi & eral & \\
\hline \multirow{5}{*}{ 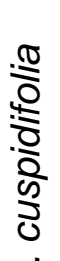 } & \multirow{3}{*}{ NPel } & CIN & 3,33 & 2,11 & 2,71 & 2,72 & & $\bar{A}$ \\
\hline & & SIN & 2,07 & 0 & 0 & 0,69 & & $B$ \\
\hline & & Média & 2,36 & 1,82 & 1,97 & 2,05 & $\mathrm{a}$ & \\
\hline & \multirow{2}{*}{ Pel } & CIN & 2,43 & 2,71 & 2,11 & 2,42 & & $A$ \\
\hline & & SIN & 1,82 & 2,11 & 0 & 1,31 & & $B$ \\
\hline \multirow[t]{2}{*}{$i$} & & Média & 2,13 & 2,41 & 1,06 & 1,86 & a & \\
\hline & \multicolumn{2}{|c|}{ Média geral } & $2,41 \mathrm{~A}$ & $1,73 \mathrm{~A}$ & $1,21 \mathrm{~A}$ & 1,78 & & \\
\hline
\end{tabular}

Obs.: Para análise estatística, os dados foram transformados em $\sqrt{x}$ e submetidos ao teste de Tukey.

Letras minúsculas na vertical comparam condição de sementes $\left(\Delta_{\text {Tukey }}=0,68\right)$

Letras maiúsculas na vertical comparam condição pós-semeadura, para cada condição de semente $\left(\Delta_{\text {Tukey }}=0,68\right)$

Letras maiúsculas na horizontal comparam os substratos $\left(\Delta_{\text {Tukey }}=1,02\right)$ 
Tabela 16. Valores médios de emergência das plântulas da espécie estudada Jacaranda cuspidifolia no grupo preenchimento + diversidade (P+D), aos $\mathbf{3 6 0}$ dias após a semeadura, nas diferentes condições testadas (NPel - sementes não peletizadas, Pel - sementes peletizadas, CIN - com incorporação da semente ao solo, SIN - sem incorporação da semente ao solo)

\begin{tabular}{|c|c|c|c|c|c|c|c|c|}
\hline & & & $\begin{array}{c}\text { Só } \\
\text { semente }\end{array}$ & Sem+M.O & $\begin{array}{c}\text { Sem+M.O+ } \\
\text { Adubo }\end{array}$ & Médi & eral & \\
\hline \multirow{5}{*}{$\begin{array}{l}\frac{\pi}{2} \\
\frac{0}{2} \\
\frac{0}{2} \\
\frac{2}{2} \\
0\end{array}$} & \multirow{2}{*}{ NPel } & CIN & 2,22 & 1,72 & 2,33 & 2,09 & & A \\
\hline & & SIN & 1,21 & 0 & 0 & 0,40 & & B \\
\hline & \multirow{3}{*}{ Pel } & Média & 1,72 & 0,86 & 1,17 & 1,25 & $a$ & \\
\hline & & CIN & 1,66 & 1,72 & 1,72 & 1,70 & & 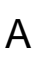 \\
\hline & & SIN & 1,21 & 1,21 & 0 & 0,81 & & B \\
\hline \multirow[t]{2}{*}{$i$} & & Média & 1,44 & 1,47 & 0,86 & 1,25 & $\mathrm{a}$ & \\
\hline & \multicolumn{2}{|c|}{ Média geral } & $1,58 \mathrm{~A}$ & $1,16 \mathrm{~A}$ & $1,01 \mathrm{~A}$ & 1,25 & & \\
\hline
\end{tabular}

Obs.: Para análise estatística, os dados foram transformados em $\sqrt{x}$ e submetidos ao teste de Tukey.

Letras minúsculas na vertical comparam condição de sementes $\left(\Delta_{\text {Tukey }}=0,75\right)$

Letras maiúsculas na vertical comparam condição pós-semeadura, para cada condição de semente $\left(\Delta_{\text {Tukey }}=0,75\right)$

Letras maiúsculas na horizontal comparam os substratos $\left(\Delta_{\text {Tukey }}=1,12\right)$

A porcentagem média de emergência de plântulas para J. cuspidifolia no grupo D entre os tratamentos aos 90 DAS em relação ao número de sementes semeadas inicialmente (30 sementes por parcela) foi de 2,34 o que representa 281 indivíduos ha $^{-1}$ (Tabela 13). Aos 360 DAS como pode ser observado na Tabela 14, a média de indivíduos estabelecidos foi de 4,78 ou 574 indivíduos ha ${ }^{-1}$. Houve um acréscimo na emergência de plântulas de $J$. cuspidifolia até aos 360 DAS quando combinada com outras espécies do grupo de diversidade, de 104,27\% comparando-se com os 90 DAS (Figura 24).

J. cuspidifolia no grupo $P+D$, entre os tratamentos a que foi submetida, obteve uma porcentagem média de emergência aos 90 DAS de 4,39 ou 523 indivíduos ha ${ }^{-1}$ (Tabela 15). Aos 360 DAS de acordo Tabela 16 a porcentagem de indivíduos estabelecidos até este período foi de 2,20 ou 264 indivíduos ha ${ }^{-1}$. 
Quando combinada com outras espécies do grupo de preenchimento e diversidade, J. cuspidifolia aos 360 DAS apresentou uma perda das plântulas emergidas de $49,52 \%$ em comparação com o primeiro período avaliado - 90 DAS (Figura 24).

A diferença de emergência de plântulas de J. cuspidifolia entre os grupos $\mathrm{P}$ e $\mathrm{P}+\mathrm{D}$ aos 90 DAS foi de $86,12 \%$. Vale destacar que nesse período, a maior porcentagem de emergência ocorreu quando a espécie foi semeada no grupo $P+D$. Esses resultados diferem daqueles apresentados para as espécies anteriores ( $P$. nitens e $P$. elegans), visto que a maior porcentagem de emergência para estas, ocorreram no grupo $P$.

J. cuspidifolia foi incrementada o número de plântulas emergidas entre o período 90 e 360 DAS no grupo P. Tal fato chama atenção por ter ocorrido somente com esta espécie. Pode-se inferir que no grupo $P+D$ a capacidade competitiva foi menor no processo pós-germinativo por estar sob condição de um número maior de sementes como já comentado para as espécies $P$. elegans e $P$. nitens. No grupo $P$ embora tenha emergido poucas plântulas inicialmente (90 DAS), no decorrer dos dias após a semeadura, J. cuspidifolia não apresentou interação negativa com outras espécies, pelo fato de estar condicionada com somente espécies de mesmo grupo (D). 


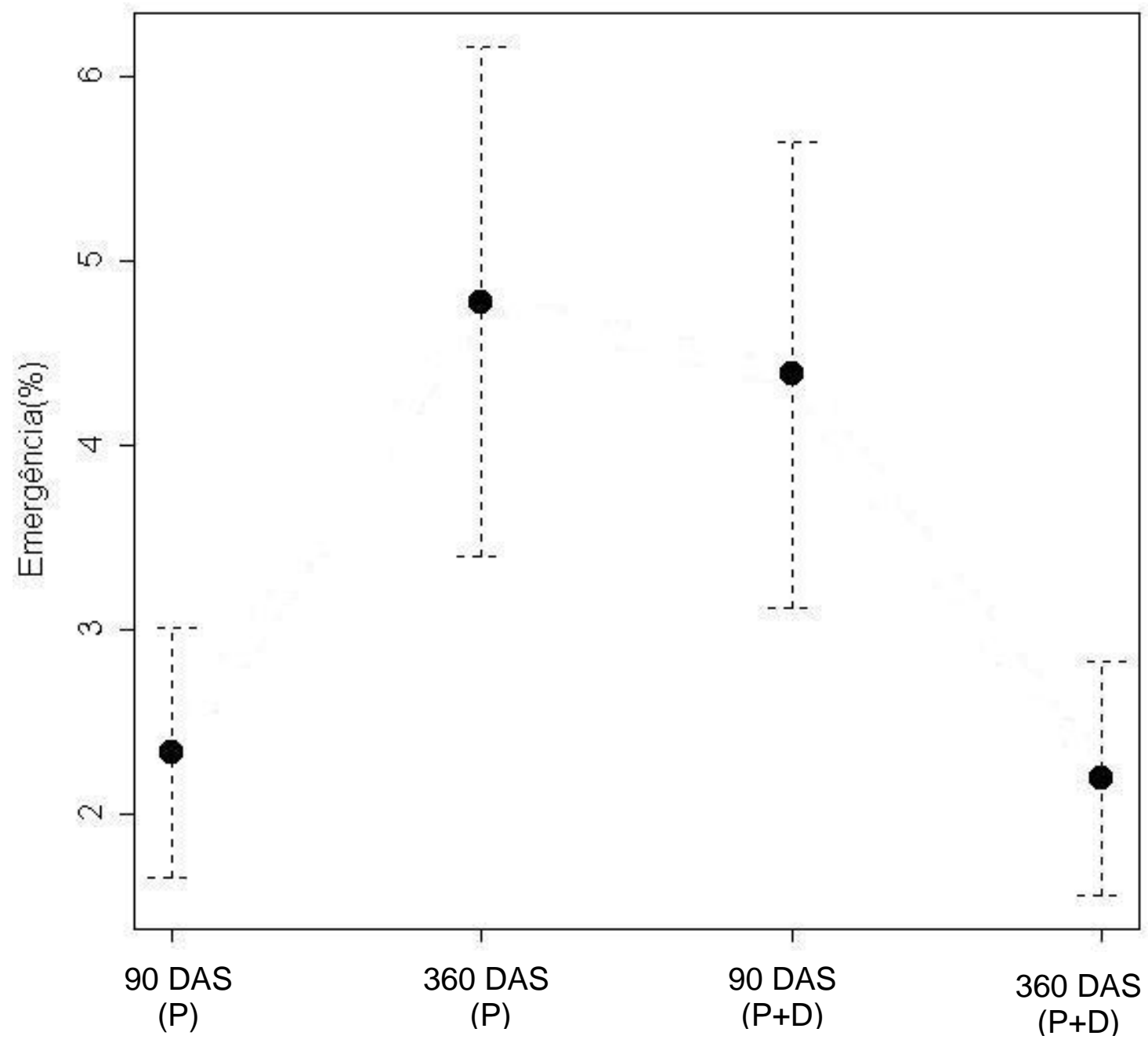

Figura 24 - Médias de porcentagens de emergência para J. cuspidifolia no grupo $\mathrm{P}$ (preenchimento) e no grupo $\mathrm{P}+\mathrm{D}$ (preenchimento $\mathrm{e}$ diversidade) aos 90 e 360 dias após a semeadura (DAS) do experimento " $A$ " do projeto de semeadura direta 


\subsubsection{Possíveis causas da não emergência das outras espécies florestais semeadas neste experimento}

Foi observado, porém não mensurado, uma intensa competição de Braquiária (Brachiaria decumbens) com as espécies florestais utilizadas neste experimento. A ocupação da área anteriormente a semeadura era de pastagem (20 anos), esta não foi tratada com herbicida pré-emergente. Isso ocorreu, por não haver na época (final de 2002), dados seguros em literatura, relatando sua aplicação no preparo de áreas destinadas ao plantio por semeadura direta de espécies nativas.

Toledo et al. (2001) estudaram em campo o efeito da densidade de plantas de Brachiaria decumbens no crescimento inicial de Eucalyptus grandis. Os autores verificaram que $B$. decumbens na densidade a partir de 4 plantas $/ \mathrm{m}^{2}$ interferiu negativamente sobre o crescimento inicial de E. grandis . Já o trabalho de Souza et al. (2003), evidencia um efeito alelopático de Brachiaria decumbens no desenvolvimento inicial de Eucalyptus grandis. Os autores ressaltam que a presença de substâncias aleloquímicas no sítio de plantio prejudica o desenvolvimento das espécies florestais em reflorestamentos.

Neste experimento observou-se que a braquiária é uma grande barreira na semeadura a lanço, visto que seu controle mecânico é inviabilizado pelo fato das espécies não estarem distribuídas uniformemente em linhas, sendo este controle feito somente por capina, o que aumentaria o custo deste método.

Como os lotes de sementes não foram estudados em laboratório ou casa de vegetação, se torna difícil tomar qualquer decisão em relação a este fator. Por outro lado, no processo de seleção das sementes, foram escolhidas somente as mais vigorosas. Vários autores lembram que a qualidade do lote de sementes e fundamental para o sucesso da semeadura (Mattei, 1996; FloresAylas, 1999, entre outros).

Apesar das espécies estudadas neste experimento serem características de programas de recuperação de áreas degradadas houve falhas 
na escolha das espécies. Dever-se-ia ter atentado para o tipo de formação florestal o que não foi possível devido à ausência de fragmentos na região.

A área experimental que é de domínio de Cerradão inicialmente foi caracterizada como domínio de Floresta Estacional Semidecidual, por estar em um ambiente ribeirinho próximo a um campo úmido. Somente quando as espécies deste experimento começaram a germinar é que foi possível identificar essa falha, que não era possível antes, pela carência de fragmentos na região. Fica evidente que na recuperação de uma área degradada a escolha de espécies regionais e de formação florestal específica é fundamental para o sucesso de reflorestamentos principalmente quando se faz o uso de semeadura direta.

Cooper $\left(2005^{1}\right)$, em estudos realizados comparando a dinâmica de água em duas formações florestais diferentes, uma de domínio de Cerradão na Estação ecológica de Assis (E.E de Assis) e outra de Floresta Estacional Semidecidual (FES) na Estação ecológica de Caetetus (E.E de Caetetus), relata que nos solos da E. E Caetetus (FES), ocorre maior retenção de água nos horizontes mais profundos ao longo de todo o ano. Isso ocorre devido às características físicas do solo nesses horizontes, inclusive micromorfologia e micromorfometria. Essas características definem uma dinâmica muito característica da água no solo dessa formação. A disponibilidade de água para plantas nesses solos está sempre na faixa de água disponível ou até em excesso, principalmente nos horizontes sub superficiais (em torno de 1 metro de profundidade) inclusive nos períodos mais secos do ano. Já na E. E de Assis onde o tipo de formação florestal é Cerradão em funções de suas características físicas, armazenam muito pouca água em seus vários horizontes, sem diferenças entre as estações do ano. As grandes variações da umidade do solo estão diretamente relacionadas com o evento chuvoso, voltando a sua condição de baixo armazenamento pouco depois de cessado o armazenamento da chuva. Essa falta d'água é mais acentuada nas camadas mais superficiais onde a disponibilidade de água para as plantas atinge o ponto de murcha em muitos

${ }^{1}$ Cooper, M. Comunicação Pessoal, 2005. 
momentos, principalmente nos períodos mais seco. $O$ autor relata que a disponibilidade da água no solo de Cerradão é muito menor que no solo da FES, principalmente considerando as camadas sub-superficiais e o tempo de residência da água no solo.

Para justificar a baixa taxa de emergência e a não emergência das espécies estudadas neste experimento, com base no trabalho acima descrito, deve ser sustentada a hipótese de que como as espécies de Cerrado são rústicas (Teixeira, 2003), suportam condições de estresse hídrico por períodos curtos. Assim, as espécies neste experimento, germinariam logo nos primeiros dias de chuva após a semeadura, mas como o solo da área é característico do cerradão, as flutuações na umidade superficial neste ambiente, são drásticas, selecionando assim, aquelas que toleram a estas condições. Possivelmente as espécies típicas da Floresta Estacional Semidecidual utilizadas neste experimento não obtiveram sucesso por estarem condicionadas a uma disponibilidade hídrica superficial muito menor do que em seu ambiente característico. Ressalva -se, que independentemente da formação florestal, a disponibilidade de água é crucial para o evento da germinação (Amaral et al., 2000). Por outro lado, para o desenvolvimento da plântula, as condições hídricas ideais dependerão da particularidade de cada espécie.

Vale ressaltar também que foi selecionado propositalmente o período 90 dias após a semeadura para realizar a primeira avaliação, pelo fato de que em alguns trabalhos realizados a partir de semeadura direta, as populações das plantas tendem a se estabelecerem neste período (Ferreira, 2002; Almeida, 2004, entre outros).

\subsection{Experimento "B"}

Nenhuma das vinte espécies semeadas neste experimento germinou em condições de campo. Provavelmente um dos fatores que impediu seu 
sucesso foi à extrema competição com a braquiária. Foi observado que em menos de um mês pós a semeadura, a braquiária, já havia tomado toda a área experimental com menor intensidade onde foi aplicado o herbicida préemergente. Almeida (2004) ressalta que a matocompetição principalmente por braquiária foi o que mais afetou a germinação e estabelecimento das espécies florestais utilizadas em seu experimento com semeadura direta.

Ferreira (2002) em experimentos testando 4 herbicidas pré-emergentes (imazapyr, atrazina, acetochlor e oxyfluorfen) relata que todas as espécies foram afetadas diretamente pelos herbicidas empregados, na altura diâmetro do colo e acúmulo de matéria seca. Na germinação das 4 espécies florestais (Senna multijuga, Senna macranthera, Trema micrantha e Solanum granulosoleprosum), o herbicida imazapyr afetou negativamente a maioria das espécies estudas com exceção de $T$. micrantha. Isso demonstra que o uso de herbicida pré-emergente deve ser cauteloso, uma vez que pode também afetar as sementes das espécies florestais semeadas.

Uma outra causa provável da não germinação das espécies florestais foi o uso de baixa densidade de sementes, visto que este experimento seria para suprir algumas dificuldades encontradas no experimento "A", principalmente em relação ao número de sementes, a fim de reduzir ainda mais o custo da recuperação, o que não foi possível.

Outro fator que vale ser destacado foi quanto à escolha das espécies utilizadas que foram praticamente em sua totalidade, características de Floresta Estacional Semidecidual (fato já comentado anteriormente para o experimento "A"), já que o ambiente é característico de Cerradão.

Por outro lado, no experimento de viveiro quase que a totalidade de espécies utilizadas germinaram.

A espécie Acacia polyphylla (monjoleiro) obteve $87 \%$ de germinação aos 90 DAS sendo a espécie com a maior taxa de germinação. Somente Cecropia pachystachya (embaúba) não apresentou nenhuma plântula. Ferreira (2003) trabalhando com semeadura direta, também não obteve sucesso com 
embaúba. O autor relata que a qualidade fisiológica (viabilidade e vigor) de lote das sementes não foram suficientemente adequada para promover a emergência de plântulas no campo.

Neste experimento, a apresentação das espécies emergidas em sementeiras no viveiro tem somente caráter informativo, e sua discussão não será levada adiante pelo fato de que não houve germinação destas no campo, já que esse era o objetivo principal deste experimento. Todavia, ressalta-se que pelos dados apresentados no experimento em sementeiras no viveiro, o lote das sementes estava viável.

Na Figura 25 estão apresentados os dados de germinação de todas as espécies testadas em sementeiras no viveiro em função de dias após a semeadura.

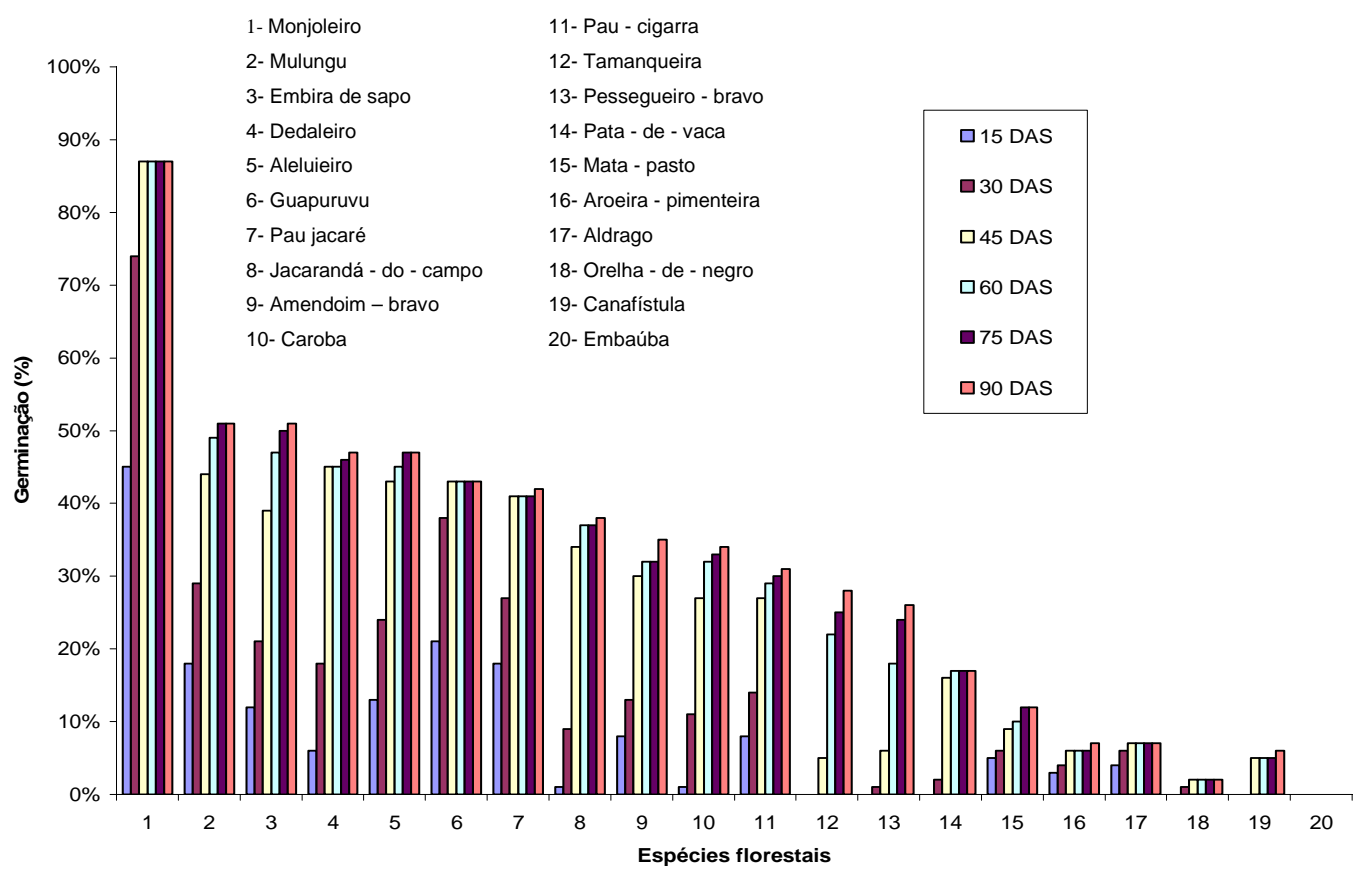

Figura 25 - Porcentagens de emergência para as espécies testadas no experimento "B" em condições de viveiro do projeto de semeadura direta 


\subsection{Consideração sobre a viabilidade metodológica e econômica da técnica} utilizada

Pelos dados apresentados anteriormente, a técnica de semeadura direta utilizada mostrou se metodologicamente viável, necessitando de apenas alguns ajustes e refinamento para potencializar seu uso. O aspecto econômico aliado ao metodológico pode tornar o ainda o método mais acessível. Para isso são necessárias algumas considerações e sugestões que serão apresentadas a seguir.

1) Em relação aos custos aplicados no experimento " $A$ ", em relação a sementes, o banco artificial foi composto por uma média de 20 sementes $/ \mathrm{m}^{2}$, com custo de sementes estimado por hectare de $R \$ 2395,00$. Ressalta-se, porém, que este custo teve como base o preço de mercado. Se houvesse coletada própria este custo poderia ser bastante reduzido.

2) Como não foi verificado efeito da adubação e uso da matéria orgânica no experimento "A", para maior parte das espécies emergidas, em solos com características semelhantes seus usos poderiam ser dispensados, não havendo neste caso, custos com adubação.

3) Devido ao fato de ter ocorrido repetidos controles de plantas competidoras, houve constantemente necessidade de custos com mão-de-obra braçal e com herbicidas pós-emergentes, principalmente no controle de braquiária no experimento "A". Este custo poderia ser reduzido se as espécies fossem semeadas em linhas, ao contrário deste experimento que foi a lanço. Isto possibilitaria uma manutenção mecânica da área que diminuiria em muito os gastos com mão-de-obra braçal. Ainda, vale destacar que em ambos os experimentos ("A" e "B") a competição com braquiária foi um fator limitante, devendo esta ser eliminada antes da semeadura das espécies florestais. Assim além de diminuir os custos com manutenção, aumentaria as chances das espécies se estabelecerem. Para isso são necessários mais estudos que avaliem os efeitos de herbicidas pré-emergentes seletivos para gramíneas 
(monocotiledôneas) sob as sementes de espécies florestais nativas dicotiledôneas, uma vez que no experimento "B" deste trabalho, parece ter sofrido influência do pré-emergente.

4) Em ambos os experimentos ("A" e "B") a semeadura foi realizada tardiamente, visto que as chuvas na região ocorrem entre outubro e março (experimento "A" semeadura em fevereiro; "B" semeadura em janeiro). Deve se atentar para realizar a semeadura no início do período chuvoso, permitindo assim, maiores condições hídricas para a germinação da semente, desenvolvimento e estabelecimento da plântula.

5) O que poderia ser testado em estudos futuros utilizando-se semeadura direta, além da incorporação das considerações já descritas anteriormente, seria usar sementes pré-germinadas ou pré-hidratadas. Para este uso é muito importante que a semeadura seja realizada na época chuvosa, pelo fato de que se não houver água suficientemente disponível logo após o plantio, certamente não resistirão dessecamento.

Com os dados apresentados neste trabalho, deve ficar claro que a semeadura direta de espécies florestais nativas é um processo que está em aprimoramento, e que ainda há muitas dificuldades a serem superadas para sua efetiva aplicabilidade, sendo necessários estudos complementares para potencializar seu uso. 


\section{CONCLUSÕES}

a) A incorporação das sementes foi efetiva para o incremento da emergência para as espécies $P$. elegans, $P$. nitens e J. cuspidifolia nos períodos avaliados (90 e 360 DAS);

b) As três espécies que emergiram $P$. elegans, $P$. nitens e J. cuspidifolia são indicadas para o sistema de semeadura a lanço já que apresentaram um bom número de indivíduos por hectare estabelecido no último período avaliado aos 360 DAS;

c) A ocupação florestal da área por espécies do início da sucessão ecológica por meio da semeadura a lanço foi efetivada, as espécies $P$. elegans, $P$. nitens e J. cuspidifolia emergiram plântulas o suficiente para cobertura florestal;

d) Embora as outras espécies testadas não foram tão expressivas quanto $P$. elegans, P. nitens e J. cuspidifolia não se descarta seu uso por meio de semeadura a lanço, havendo a necessidade de estudos complementares para identificar algumas dificuldades encontradas neste projeto;

e) O sistema de semeadura a lanço mostrou-se viável e promissor para ser utilizado para recuperação de áreas degradadas, conseguindo nesse experimento até 874 indivíduos ha ${ }^{-1}$ pertencentes o grupo de preenchimento e 1902 indivíduos ha ${ }^{-1}$ pertencentes ao grupo de diversidade; 
f) A semeadura a lanço em áreas não ocupadas com vegetação é um método adequado para ocupação de área com baixa diversidade, que deverão ser enriquecidas numa ação futura inclusive utilizando-se a semeadura direta. 
ANEXOS 
Anexo A

Análises de solo

Tabela 1. Característica do solo da área experimental (macronutrientes)

CARACTERÍSTICAS

\begin{tabular}{|c|c|c|c|c|c|c|c|c|c|c|c|c|c|}
\hline \multirow{2}{*}{$\begin{array}{l}\text { Profundidade } \\
\text { do solo }(\mathrm{cm})\end{array}$} & \multirow{2}{*}{$\begin{array}{c}\mathrm{pH} \\
\mathrm{CaCl} 2\end{array}$} & \multirow{2}{*}{$\begin{array}{c}\text { M.O } \\
\mathrm{g} \mathrm{dm}^{-3}\end{array}$} & $\mathrm{P}$ & $\mathrm{s}$ & $\mathrm{K}$ & $\mathrm{Ca}$ & $\mathrm{Mg}$ & Al & $\mathrm{H}+\mathrm{Al}$ & SB & $\mathrm{T}$ & $\mathrm{V}^{\mathrm{a}}$ & $\mathrm{M}^{\mathrm{b}}$ \\
\hline & & & \multicolumn{2}{|c|}{$\mathrm{mg} \mathrm{dm}^{-3}$} & \multicolumn{7}{|c|}{ mmolc dm ${ }^{-3}$} & \multicolumn{2}{|c|}{$\%$} \\
\hline $0-20$ & 5,2 & 38 & 23 & 6 & 1,9 & 51 & 21 & 0 & 42 & 73,9 & 115,9 & 64 & 0 \\
\hline $20-40$ & 5,0 & 28 & 20 & 5 & 0,5 & 41 & 18 & 0 & 42 & 59,5 & 101,5 & 59 & 0 \\
\hline
\end{tabular}

$\mathrm{a}-\mathrm{V}$ : porcentagem de saturação por bases

b - m: caráter álico

Tabela 2. Característica do solo da área experimental (micronutrientes)

CARACTERÍSTICAS

\begin{tabular}{cccccc}
\hline $\begin{array}{c}\text { Profundidade do } \\
\text { solo (cm) }\end{array}$ & $\mathrm{B}$ & $\mathrm{Cu}$ & $\mathrm{Fe}$ & $\mathrm{Mn}$ & $\mathrm{Zn}$ \\
\cline { 2 - 6 } & & \multicolumn{5}{c}{$\mathrm{mg} \mathrm{dm}^{-3}$} \\
\hline $0-20$ & 2,30 & 9,1 & 75 & 42,6 & 0,7 \\
$20-40$ & 2,13 & 7,8 & 59 & 31,4 & 0,5 \\
\hline
\end{tabular}


Anexo B

Descrição das espécies florestais do grupo de preenchimento, utilizadas no experimento " $A$ "

Acacia polyphylla DC.

A A. polyphylla (Família: Mimosaceae), também conhecida popularmente como monjoleiro, é uma espécie semidecídua ou decídua, seletiva xerófita, heliófita e pioneira de vasta e expressiva dispersão pelas florestas primárias do rio Paraná (Reitz, 1979; Lorenzi, 1992). A madeira é usada na marcenaria, torno e obras internas. Como espécie pioneira e rústica, é muito utilizada em reflorestamentos para recuperação de áreas degradadas (Lorenzi, 1992).

Albizia hasslerii (Chodat) Burr.

A A. hasslerii (Família: Mimosaceae), popularmente conhecida como farinha-seca é uma espécie decídua, heliófita, pioneira, característica da floresta latifoliada semidecídua da bacia do Paraná. Sua madeira é utilizada na fabricação de brinquedos, caixotaria, entre outras (Lorenzi, 1992). A farinhaseca é uma espécie excelente para plantios mistos destinados á recomposição de áreas degradadas não inundadas (Rodrigues et al., 2003).

Anadenanthera falcata Benth. Spreng.

A A. falcata (Família: Mimosaceae), popularmente conhecida como angico-do-cerrado é uma espécie decídua, heliófita, seletiva xerófita, pioneira a secundária inicial, característica do cerrado. Sua madeira é usada na construção civil, marcenaria e carpintaria, entre outras. O angico-do-cerrado é uma espécie recomendada para reflorestamento em áreas ciliares sujeita a inundações periódicas com encharcamento leve (Carvalho, 1994). 
Bauhinia forficata Link

A B. forficata (Família: Caesalpiniaceae), popularmente conhecida como pata-de-vaca é uma espécie decídua ou semidecídua, heliófita, pioneira, característica da floresta pluvial atlântica. Ocorre principalmente na floresta aluvial Atlântica (Lorenzi, 1992; Carvalho, 1994). Sua madeira é utilizada para caixotaria e obras leves e os ramos e troncos inteiros para lenha e carvão. Esta espécie é indicada para reflorestamentos em áreas ciliares sujeitas a inundações periódicas de rápida duração (Carvalho, 1994).

Casearia sylvestris Sw.

A C. sylvestris (Família: Flacourtiaceae), popularmente conhecida como guaçatonga é uma espécie heliófita, perenifólia, seletiva higrófita, pioneira. Ocorre em todo o território brasileiro, em quase todas formações florestais $A$ madeira é usada para construção civil, tábuas para assoalhos, marcenaria e carpintaria, lenha e carvão (Lorenzi, 1992). Os frutos e sementes da guaçatonga são dispersos por pássaros (Sanchotene, 1989). Esta espécie é indicada para reflorestamento em áreas degradadas pela capacidade de atração da avifauna (Rodrigues et al., 2003).

Cecropia pachystachya Trec.

A C. pachystachya (Família: Cecropiaceae), conhecida popularmente como embaúba, é uma espécie perenifólia, heliófita, pioneira e seletiva higrófita. Sua madeira é usada na confecção de caixotaria, lápis, compensados, brinquedos e polpa celulósica. Suas folhas são apreciadas por bicho-preguiça, e os frutos, produzidos anualmente em farta quantidade, são procurados por muitas espécies de aves. É uma espécie indispensável em reflorestamentos de áreas de preservação permanente, por ser atrativa da fauna e apresentar crescimento rápido (Lorenzi, 1992; Rodrigues et al., 2003). 
Platypodium elegans Vog.

A Platypodium elegans (Família: Fabaceae), popularmente conhecida como jacarandá-do-campo é uma espécie semidecídua, heliófita, seletiva xerófita, pioneira, característica do cerrado localizado em terrenos bem drenado e em sua transição para a floresta semidecídua. Sua madeira é usada na carpintaria e marcenaria, cabos de ferramentas, entre outras (Lorenzi, 1992). O jacarandá-do-campo é uma espécie indispensável nos reflorestamentos para restauração florestal por ser uma espécie rústica e de crescimento rápido (Lorenzi, 1992; Rodrigues et al., 2003).

Pterogyne nitens Tul.

A P. nitens (Família: Caesalpiniaceae), popularmente conhecida por amendoin-bravo é uma espécie decídua, heliófita, pioneira, característica da floresta latifoliada semidecídua, embora ocorra em algumas áreas úmidas com vegetação florestal na caatinga. Sua madeira é usada para fabricação de móveis finos, carpintaria em geral, assoalho, construção civil, interiores de vagões ferroviários e de embarcações, implementos agrícolas, entre outros (Lorenzi, 1992; Carvalho, 1994). O amendoin-bravo é uma espécie recomendada para reflorestamento em áreas ciliares, suportando encharcamento leve (Rodrigues et al., 2003). É também indicada para revegetação em áreas arenosas (Carvalho, 1994). Esta espécie corre risco de extinção no Estado de São Paulo, estando na "lista das espécies para conservação genética no Estado de São Paulo" (Siqueira \& Nogueira, 1992).

Solanum erianthum D. Don

A S. erianthum (Família: Solanaceae), popularmente conhecida por fumo-bravo é uma espécie perene, heliófita, arbustiva e pioneira que se desenvolve em variados tipos de solos (Reitz, 1966; Kissmann \& Groth, 1995). 
Ocorre em todo território brasileiro e é muito confundida com as espécies Solanum granuloso-leprosum e Solanum mauritianum. O fumo-bravo é uma espécie importantíssima na restauração florestal, pois seus frutos são muito apreciados e disseminados por algumas aves e morcegos (Kissmann \& Groth, 1995).

Trema micrantha (L.) Blume

A T. Micrantha (Família: Ulmaceae), também conhecida popularmente como pau-pólvora, é uma espécie pioneira, heliófita, de ocorrência natural desde o Estados Unidos até o Brasil (Carvalho, 1994). Ocorre em todos os tipos de ambientes, exceto nos muito úmidos, o que explica a sua vasta dispersão. Produz anualmente uma grande quantidade de sementes, amplamente disseminadas por pássaros (Lorenzi, 1992). Pode ser usada em plantios mistos para recuperação de ecossistemas degradados, junto a espécies secundárias e climácicas (Carvalho, 1994; Barbosa et al., 1997b) e para reflorestamentos em áreas ciliares, pois seus frutos são bastante apreciados por aves e peixes (Carvalho, 1994, Rodrigues et al., 2003). A sua madeira é usada para diversas finalidades, tendo como principais usos, esculturas, caixotaria, esquadrias, móveis rústicos, tabuado, palitos lenha, carvão e eventualmente para postes (Carvalho, 1994).

Descrição das espécies florestais do grupo de diversidade, utilizadas no experimento " $A$ "

Cedrella fissilis (vell)

A C. fissilis (Família: Meliaceae), popularmente conhecida como cedro é uma espécie decídua, heliófita, secundária inicial ou tardia, característico das florestas semidecíduas e menos freqüente na floresta ombrófila densa. Ocorre preferencialmente em solos úmidos e profundos como os encontrados nos vales 
e planícies aluviais, e desenvolvem-se no interior das florestas primárias, podendo ser igualmente encontrada com espécie pioneira na vegetação secundária. Sua madeira é usada em construção civil, naval, instrumentos musicais, entre outras. A casca do cedro possui substâncias tônicas e adstringentes que é muito usada na medicina popular na forma de chá para o tratamento de várias enfermidades. Esta espécie é recomendada para reflorestamentos em áreas degradadas sem inundação (Carvalho, 1994).

Croton floribundus Spreng.

A C. floribundus (Família: Euphorbiaceae), popularmente conhecida por capixingui é uma espécie decídua ou semidecídua, heliófita, secundária inicial, característica de matas secundárias da floresta semidecídua. Ocorre principalmente na floresta latifoliada semidecídua (Lorenzi, 1992). Sua madeira é usada na fabricação de tamancos, caixotaria leve, artefatos de madeira, brinquedos (Lorenzi, 1992; Carvalho, 1994). O capixingui possui propriedades medicinais, e o uso das cascas, folhas e ramos são usados na medicina humana e veterinária (Brandão, 1991). Esta espécie é muito utilizada na colonização de áreas degradadas por apresentar rápido crescimento e na reposição ciliar, é indicada para terrenos bem drenados (Carvalho, 1994).

Citharexyllum myrianthum Cham.

A C. myrianthum (Família: Verbenaceae), popularmente conhecida como pau-viola é uma espécie decídua, heliófita, seletiva higrófita, secundária característica das florestas de galeria e pluvial atlântica. Sua madeira é usada para caixotaria, embalagens leves, guitarras, violas entre outras. O pau-viola é uma espécie bastante comum nos reflorestamento para fins de restauração florestal, pois seus frutos são apreciados e disseminados pela avifauna silvestre (Lorenzi, 1992; Carvalho, 1994; Rodrigues et al., 2003). 
Dilodendron bipinnatum Radkl.

A D. bipinnatum (Família: Sapindaceae), popularmente conhecida como maria-pobre é uma espécie semidecídua, heliófita, secundária inicial, seletiva higrófita, característica e exclusiva de solos úmidos da floresta semidecídua do Brasil central. Sua madeira é usada para lenha. A maria-pobre é uma grande atrativa da avifauna, sendo indispensável em reflorestamento de áreas ciliares (Lorenzi, 1992).

Genipa americana L.

A G. americana (Família: Rubiaceae) popularmente conhecida por jenipapo é uma espécie secundária inicial, semidecídua, heliófita, seletiva higrófita, característica das florestas pluvial e semidecídua situada em várzeas úmidas e brejosas. Ocorre em todo o território brasileiro. Sua madeira é utilizada na construção civil, marcenaria, móveis, entre outras (Lorenzi, 1992). Seu uso medicinal é muito difundido na medicina popular. Das sementes, frutos, folhas, raízes, casca, são extraídos compostos medicinais para o tratamento de várias doenças. O jenipapo é também muito apreciado como alimento. Esta espécie é de grande valor ecológico em reflorestamento para recuperação de áreas degradadas, principalmente em áreas ciliares, por resistir a encharcamento de média e longa duração, além de ser fonte de alimento para diversas espécies de aves, mamíferos e peixes (Carvalho, 1994).

Jacaranda cuspidifolia Mart.

A J. cuspidifolia (Família: Bignoniaceae), popularmente conhecida como caroba, é uma espécie decídua, heliófita, secundária inicial, característica da floresta semidecídua de altitude. Sua madeira é muito usada na marcenaria (Lorenzi, 1992). Seus frutos quando secos são usados para fabricação de artesanatos como: brincos, colares, enfeites, etc. (observação pessoal). Por 
apresentar crescimento rápido é muito utilizada na recuperação de áreas ciliares (Rodrigues et al., 2003).

Myracrodruon urundeuva Fr. All.

A M. urundeuva (Família: Anacardiaceae), popularmente conhecida como aroeira-verdadeira é uma espécie decídua, heliófita, seletiva xerófita, secundária tardia e característica de terrenos secos e rochosos (Lorenzi, 1992). Sua madeira é usada para formação de cercas, seja como mourão, batente, estaca, palanque ou balancim; em construção civil, móveis e peças torneadas (Carvalho, 1994). Segundo Carvalho (1994), a casca, folha e raiz da aroeiraverdadeira são usadas tradicionalmente na medicina caseira em aguardente, como balsâmica e hemostática. Esta espécie está na "lista oficial de espécies da flora brasileira ameaçada de extinção", na categoria vulnerável (Portaria n. 006/92-N, 15 de janeiro de 1992).

Ormosia arborea (Vell.) Harms.

A O. arborea (Família: Fabaceae), popularmente conhecida como olhode-cabra é uma espécie semidecídua ou perenifólia, heliófita, secundária inicial, característica da floresta latifoliada semidecídua e pluvial atlântica. Sua madeira é utilizada na confecção de móveis, construção civil, entre outros (Lorenzi, 1992). As sementes e frutos do olho-de-cabra são usados para fabricação de artesanatos como: brincos, colares, pulseiras, etc. (observação pessoal). É uma espécie indicada para reflorestamento de áreas degradadas (Rodrigues et al., 2003). 
Psidium guajava L.

A P. guajava (Família: Myrtaceae), popularmente conhecida como goiabeira é uma espécie semidecídua, heliófita e seletiva higrófita e secundária inicial. Ocorre na floresta pluvial atlântica; espontaneamente em quase todo Brasil. Sua madeira é usada para esteios, moirões, cabos de ferramentas, cangas, entre outras. Seu fruto é muito apreciado e comum, sendo consumidos in natura, ou industrializados na forma de: doces, geléia, suco, etc (Lorenzi, 1992). A goiabeira é uma espécie importantíssima em reflorestamentos para recuperação de áreas degradadas por ser atrativa da avifauna (Rodrigues et al., 2003).

\section{Zanthoxylum rhoifolium L.}

A Z. rhoifolium (Família: Rutaceae), popularmente conhecida como mamica-de-porca é uma espécie semidecídua, secundária inicial, heliófita e seletiva xerófita até mesófita, característica da mata pluvial atlântica. Ocorre em todo país. Sua madeira é usada para construção civil, marcenaria, carpintaria, calçados (Lorenzi, 1992). A mamica-de-porca é uma espécie recomendada para a recuperação de áreas degradadas por ser atrativa de avifauna (Rodrigues et a., 2003) 
Anexo C

Descrição das espécies florestais do grupo preenchimento utilizadas no experimento "B"

Acacia polyphylla DC. (já descrita no Anexo B)

Aegiphila sellowiana Cham.

A A. sellowiana (Família: Verbenaceae), popularmente conhecida como tamanqueira é uma espécie decídua, heliófita, pioneira, indiferente às condições físicas do solo, características das formações florestais pluvial e semidecíduas. Sua madeira é usada para obras internas, caixotaria, confecção de tamancos, entre outras (Lorenzi, 1992). A tamanqueira é uma espécie muito importante na recomposição florestal e seus frutos são apreciados por diversas espécies da avifauna (Lorenzi, 1992; Rodrigues, 2003).

Bauhinia forficata Link (já descrita no Anexo B)

Cecropia pachystachya Trec. (já descrita no Anexo B)

Enterolobium contortisiliquum (Vell) Morong

A E. contortisiliquum (Família: Mimosaceae), popularmente conhecida como orelha-de-negro é uma decídua no inverno, heliófita, seletiva higrófita, espécie pioneira ou secundária inicial, dispersa em várias formações florestais. Sua madeira é utilizada na fabricação de brinquedos, construção naval e civil, canoa de tronco inteiro, entre outras. Seus frutos contêm saponina hemolítica, sendo muito comum na medicina popular. Esta espécie é indicada para reflorestamentos em áreas ciliares, sendo resistente a inundações periódicas de rápida duração e apresenta crescimento muito rápido no campo, além de ser 
uma fonte nutridora para várias espécies silvestres, como a paca e a cutia, que são seus principais dispersores de sementes (Carvalho, 1994). A orelha-denegro esta na lista de espécies que correm perigo de extinção no Estado de São Paulo (Siqueira \& Nogueira, 1992)

\section{Erythrina speciosa Andrews}

A E. speciosa (Família: Fabaceae), popularmente conhecida como mulungu é uma espécie decídua, heliófita, pioneira, seletiva higrófita. $\mathrm{O}$ mulungu é uma espécie muito importante nos reflorestamentos para recuperação de áreas degradadas, pois apresenta rápido crescimento e é bem adaptada a lugares úmidos ideal para áreas ciliares (Lorenzi, 1992).

Jacaranda cuspidifolia Mart. (já descrita no Anexo B)

\section{Lafoensia pacari St. Hil}

A L. pacari (Família: Lythraceae), popularmente conhecida como dedaleiro é uma espécie decídua, heliófita, indiferente às condições físicas do solo, pioneira, característica das florestas de altitude (latifoliada semidecídua e de pinhais), embora seja encontrada em outros ecossistemas como o Cerrado. Sua madeira é usada para construção civil, marcenaria, cabo de ferramentas, moirões entre outras. Os índios guaranis utilizam o dedaleiro para fabricação de flechas (Carvalho, 1994). Seu uso medicinal é bastante difundido na medicina popular; suas folhas têm usos diaforéticas, uso interno, em infusão (Brandão, 1991). É uma espécie recomendada para reflorestamento, e a interação com seu polinizador (morcegos grandes) é muito valiosa na recuperação ecossistemas degradados (Carvalho, 1994). 
Lonchocarpus muehlbergianus Hassl.

A L. muehlbergianus (Família: Fabaceae), popularmente conhecida por embira-de-sapo é uma espécie decídua, heliófita, pioneira, característica das florestas semidecíduas. Sua madeira é usada para carpintaria leve, cabos de ferramentas, caixotaria, entre outras. A embira-de-sapo é uma espécie pioneira e rústica indispensável em reflorestamentos em áreas degradadas (Lorenzi, 1992).

Peltophorum dubium (Spreng)Taub.

A P. dubium (Família: Caesalpiniaceae), popularmente conhecida como canafístula é uma espécie heliófita, pioneira, classificando-a como espécie com aptidão à regeneração artificial (Carvalho, 1994). Sua madeira é utilizada na construção civil, naval, em indústrias de móveis, carpintaria e marcenaria. As raízes, folhas, flores e frutos da canafístula possuem propriedades medicinais e é são muito utilizadas na medicina popular (Reitz, 1978; Carvalho, 1994).

Piptadenia gonoacantha (Mart.) J.F.Macbr

A P. gonoacantha (Família: Mimosaceae), conhecida popularmente por pau-jacaré, é uma espécie semidecídua, heliófita e seletiva higrófita, pioneira a secundária inicial. Ocorre principalmente na Floresta Pluvial da encosta Atlântica (Lorenzi, 1992). Sua madeira é utilizada na fabricação de brinquedos, acabamentos internos, obras não expostas, entre outras. O pau-jacaré é uma espécie indicada para a recuperação de ambientes degradados não inundados (Carvalho, 1994; Rodrigues et al., 2003). 
Platypodium elegans Vog. (já descrita no Anexo B)

Prunus myrtifolia (L.) Urb.

A P. myrtifolia (Família: Rosaceae) popularmente conhecida por pessegueiro-bravo é uma árvore perenifólia, secundária inicial, encontrada na Floresta Ombrófila Mista, Floresta Estacional Decidual, Floresta Estacional Baixo Montana, Floresta Ombrófila Densa, Campo rupestres ou de altitude em Minas Gerais e Restinga. Sua madeira é usada na construção civil, cabos de ferramentas, peças torneadas, entre outros. Também usado como medicinal, folhas do pessegueiro-bravo é um energético calmante para tosses e asma, porém sua semente é considerada venenosa. É uma espécie indispensável em reflorestamentos para recuperação florestal pela atratividade da avifauna (Carvalho, 1994).

Pterocarpus violaceus Vog.

A P. violaceus (Família: Fabaceae), popularmente conhecida por aldrago é uma espécie perenifólia, heliófita, pioneira, aparentemente indiferente às condições físicas do solo, característica da floresta pluvial de encosta atlântica. Sua madeira é utilizada para acabamentos internos, como guarnições, rodapés, molduras, para confecção de peças torneadas, entre outras. O aldrago é uma espécie bem adaptada à insolação direta e é de fácil multiplicação. Por estas características é indispensável em reflorestamentos para recuperação florestal (Lorenzi, 1992).

Pterogyne nitens Tul. (já descrita no Anexo B) 
Schinus terebinthifolius Raddi.

A S. terebenthifolius (Família: Anacardiaceae), também conhecida popularmente por aroeira-pimenteira, é uma espécie perenifólia, heliófita e pioneira, de ocorrência comum em beira de rios, córregos e várzeas úmidas de formações secundárias, desenvolvem também em terrenos secos e pobres. Seus frutos são apreciados por várias espécies de aves, e suas sementes são amplamente disseminadas, o que caracteriza sua importância em reflorestamentos para recuperação de áreas degradadas (Lorenzi, 1992; Rodrigues et al., 2003). A madeira é utilizada para moirões, esteios, lenha e carvão (Lorenzi, 1992; Carvalho, 1994). De suas folhas, ramos e cascas são extraídos produtos medicinais e as sementes são usadas como condimento alimentar.

Schizolobium parahyba (Vell.) Blake

A S. parahyba (Família: Caesalpiniaceae), popularmente conhecida como guapuruvu, é uma espécie decídua, heliófita, pioneira e seletiva higrófita e exclusiva da mata atlântica. Sua madeira é utilizada para fabricação de brinquedos, miolo de painéis e portas, saltos para calçados, compensados, caixotaria leve e pesada e formas para concreto (Lorenzi, 1992). Segundo Kuhlmann \& Kuhn (1947), os galhos do guapuruvu, são preferidos para a nidificação do pássaro “joão-de-barro". Por apresentar crescimento rápido, esta espécie é ideal para revegetação em áreas degradadas. Sua casca possui propriedades medicinais e é usada na medicina popular (Carvalho, 1994).

Senna alata (L.) Roxb.

A S. alata (Família: Fabaceae), popularmente conhecida por matapasto é uma espécie heliófita, arbustiva e pioneira. Ocorre em todo o país e como o próprio nome prediz é muito abundante em pastagens. O mata-pasto é 
uma espécie muito usada em reflorestamentos para recuperação de áreas degradadas por ser rústica e de crescimento rápido (Rodrigues, 2003).

Senna multijuga (Rich)Irwin et Barn.

A S Multijuga (Família: Mimosaceae), conhecida popularmente como pau-cigarra é uma espécie heliófita, pioneira de ocorrência principalmente na mata pluvial da costa atlântica (Carvalho, 1994). Devido a sua adaptação a diversos tipos de solos, própria para utilização em programas revegetação em áreas degradadas e matas ciliares, como também para arborização de ruas, parques e jardins (Lorenzi, 1992). As sementes são produzidas em grande quantidade e dispersadas por autocoria. As sementes apresentam dormência, formando banco de sementes (Carvalho, 1994). A sua madeira é utilizada para caixotaria leve, confecção de brinquedos, lenha e carvão (Lorenzi, 1992).

Sesbania sesban (L.) Merr.

A S. sesban (Família: Fabaceae), popularmente conhecida como aleluieiro, é uma espécie arbustiva, heliófita e pioneira que ocorre naturalmente no semi-árido até regiões subúmidas, com precipitação entre 500 e 2000mm. Adapta-se bem em locais com estações definidas (seca e chuvosa) e tolera o encharcamento. É uma espécie que cresce rapidamente até $8 \mathrm{~m}$ de altura, contêm ramificações e sua madeira é leve, sendo utilizada para forragem e adubação verde (Ferreira, 2002). O aleluieiro é uma espécie indicada para recuperação de áreas degradadas por recobrir rapidamente o solo e ser uma ótima fixadora de nitrogênio (Costa, 2001; Ferreira, 2002; Rodrigues, 2003). 
Anexo D

Tabela 1. Quadro de análise de variância para emergência de plântulas de $P$. elegans no grupo $\mathrm{P}$ do experimento " $A$ " do projeto de semeadura direta aos 90 dias após a semeadura. Morro Agudo - SP, 2005

\begin{tabular}{|c|c|c|c|c|c|}
\hline $\begin{array}{l}\text { CAUSA DE } \\
\text { VARIAÇÃO }\end{array}$ & G.L & S.Q & Q.M & $F$ & Interpr. \\
\hline SEM. & 1 & 0,0023 & 0,0023 & 0,0035 & ns \\
\hline SUBS. & 2 & 4,7188 & 2,3594 & 3,5729 & * \\
\hline COND. & 1 & 28,5334 & 28,5334 & 43,2097 & ** \\
\hline SEMxSUBS & 2 & 1,9558 & 0,9779 & 1,4809 & ns \\
\hline SEMXCOND & 1 & 0,8556 & 0,8556 & 1,2957 & ns \\
\hline SUBSXCOND & 2 & 0,4978 & 0,2489 & 0,3770 & ns \\
\hline SEMxSUBSXCOND & 2 & 0,0514 & 0,0257 & 0,0389 & ns \\
\hline TRATAMENTOS & 11 & 36,6152 & 3,3287 & & \\
\hline BLOCOS & 2 & 1,1964 & 0,5982 & & \\
\hline RESÍDUO & 22 & 14,5276 & 0,6603 & & \\
\hline
\end{tabular}

Tabela 2. Quadro de análise de variância para emergência de plântulas de $P$. elegans no grupo $\mathrm{P}$ do experimento " $\mathrm{A}$ " do projeto de semeadura direta aos 360 dias após a semeadura. Morro Agudo - SP, 2005

\begin{tabular}{|c|c|c|c|c|c|}
\hline $\begin{array}{l}\text { CAUSA DE } \\
\text { VARIAÇÃOO }\end{array}$ & G.L & S.Q & Q.M & $\mathrm{F}$ & Interpr \\
\hline SEM. & 1 & 1,1378 & 1,1378 & 1,1916 & ns \\
\hline SUBS. & 2 & 1,9470 & 0,9735 & 1,0196 & ns \\
\hline COND. & 1 & 19,1552 & 19,1552 & 20,0615 & ** \\
\hline SEMXSUBS & 2 & 0,7956 & 0,3978 & 0,4166 & ns \\
\hline SEMXCOND & 1 & 0,2844 & 0,2844 & 0,2979 & ns \\
\hline SUBSXCOND & 2 & 3,6537 & 1,8268 & 1,9133 & ns \\
\hline SEMxSUBSxCOND & 2 & 4,6143 & 2,3071 & 2,4163 & ns \\
\hline TRATAMENTOS & 11 & 31,5881 & 2,8716 & & \\
\hline BLOCOS & 2 & 3,8967 & 1,9484 & & \\
\hline RESÍDUO & 22 & 21,0061 & 0,9548 & & \\
\hline
\end{tabular}


Tabela 3. Quadro de análise de variância para emergência de plântulas de $P$. elegans no grupo $P+D$ do experimento " $A$ " do projeto de semeadura direta aos 90 dias após a semeadura. Morro Agudo - SP, 2005

\begin{tabular}{|c|c|c|c|c|c|}
\hline $\begin{array}{l}\text { CAUSA DE } \\
\text { VARIAÇÃO }\end{array}$ & G.L & S.Q & Q.M & $\mathrm{F}$ & Interpr. \\
\hline SEM. & 1 & 0,3990 & 0,3990 & 0,2069 & ns \\
\hline SUBS. & 2 & 0,5027 & 0,2514 & 0,1303 & ns \\
\hline COND. & 1 & 15,3272 & 15,3272 & 7,9468 & ** \\
\hline SEMXSUBS & 2 & 1,5548 & 0,7774 & 0,4031 & ns \\
\hline SEMXCOND & 1 & 0,0851 & 0,0851 & 0,0441 & ns \\
\hline SUBSxCOND & 2 & 5,2210 & 2,6105 & 1,3535 & ns \\
\hline SEMxSUBSxCOND & 2 & 0,5299 & 0,2649 & 0,1374 & ns \\
\hline TRATAMENTOS & 11 & 23,6196 & 2,1472 & & \\
\hline BLOCOS & 2 & 1,8617 & 0,9308 & & \\
\hline RESÍDUO & 22 & 42,4318 & 1,9287 & & \\
\hline
\end{tabular}

Tabela 4. Quadro de análise de variância para emergência de plântulas de P. elegans no grupo $P+D$ do experimento " $A$ " do projeto de semeadura direta aos 360 dias após a semeadura. Morro Agudo - SP, 2005

\begin{tabular}{|c|c|c|c|c|c|}
\hline $\begin{array}{l}\text { CAUSA DE } \\
\text { VARIAÇÃO }\end{array}$ & G.L & S.Q & Q.M & $\mathrm{F}$ & Interpr \\
\hline SEM. & 1 & 1,4762 & 1,4762 & 1,8177 & ns \\
\hline SUBS. & 2 & 0,1526 & 0,0763 & 0,0940 & ns \\
\hline COND. & 1 & 13,9751 & 13,9751 & 17,2074 & $\star *$ \\
\hline SEMXSUBS & 2 & 1,5287 & 0,7644 & 0,9411 & ns \\
\hline SEMXCOND & 1 & 1,2958 & 1,2958 & 1,5955 & ns \\
\hline SUBSXCOND & 2 & 1,5312 & 0,7656 & 0,9427 & ns \\
\hline SEMXSUBSxCOND & 2 & 2,7918 & 1,3959 & 1,7188 & ns \\
\hline TRATAMENTOS & 11 & 22,7515 & 2,0683 & & \\
\hline BLOCOS & 2 & 1,5617 & 0,7808 & & \\
\hline RESÍDUO & 22 & 17,8675 & 0,8122 & & \\
\hline
\end{tabular}


Tabela 5. Quadro de análise de variância para emergência de plântulas de $P$. nitens no grupo $\mathrm{P}$ do experimento " $\mathrm{A}$ " do projeto de semeadura direta aos 90 dias após a semeadura. Morro Agudo - SP, 2005

\begin{tabular}{|c|c|c|c|c|c|}
\hline $\begin{array}{l}\text { CAUSA DE } \\
\text { VARIAÇÃ̃O }\end{array}$ & G.L & S.Q & Q.M & $\mathrm{F}$ & Interpr. \\
\hline SEM. & 1 & 4,0267 & 4,0267 & 2,9397 & ns \\
\hline SUBS. & 2 & 6,6366 & 3,3183 & 2,4225 & ns \\
\hline COND. & 1 & 2,4128 & 2,4128 & 1,7615 & ns \\
\hline SEMXSUBS & 2 & 3,6557 & 1,8279 & 1,3344 & ns \\
\hline SEMXCOND & 1 & 2,1609 & 2,1609 & 1,5776 & ns \\
\hline SUBSxCOND & 2 & 0,7087 & 0,3544 & 0,2587 & ns \\
\hline SEMXSUBSXCOND & 2 & 1,0840 & 0,5420 & 0,3957 & ns \\
\hline TRATAMENTOS & 11 & 20,6855 & 1,8805 & & \\
\hline BLOCOS & 2 & 7,8084 & 3,9042 & & \\
\hline RESÍDUO & 22 & 30,1347 & 1,3698 & & \\
\hline
\end{tabular}

Tabela 6. Quadro de análise de variância para emergência de plântulas de $P$. nitens do grupo $\mathrm{P}$ experimento " $\mathrm{A}$ " do projeto de semeadura direta aos 360 dias após a semeadura. Morro Agudo - SP, 2005

\begin{tabular}{|c|c|c|c|c|c|}
\hline $\begin{array}{l}\text { CAUSA DE } \\
\text { VARIAÇÃO }\end{array}$ & G.L & S.Q & Q.M & $\mathrm{F}$ & Interpr. \\
\hline SEM. & 1 & 4,2230 & 4,2230 & 2,7734 & ns \\
\hline SUBS. & 2 & 6,8835 & 3,4418 & 2,2603 & ns \\
\hline COND. & 1 & 4,4732 & 4,4732 & 2,9377 & ns \\
\hline SEMXSUBS & 2 & 0,8340 & 0,4170 & 0,2739 & ns \\
\hline SEMXCOND & 1 & 2,3053 & 2,3053 & 1,5140 & ns \\
\hline SUBSXCOND & 2 & 0,8479 & 0,4239 & 0,2784 & ns \\
\hline SEMXSUBSXCOND & 2 & 1,3700 & 0,6850 & 0,4499 & ns \\
\hline TRATAMENTOS & 11 & 20,9370 & 1,9034 & & \\
\hline BLOCOS & 2 & 7,5754 & 3,7877 & & \\
\hline RESÍDUO & 22 & 33,4989 & 1,5227 & & \\
\hline
\end{tabular}


Tabela 7. Quadro de análise de variância para emergência de plântulas de $P$. nitens do grupo $P+D$ experimento "A" do projeto de semeadura direta aos 90 dias após a semeadura. Morro Agudo - SP, 2005

\begin{tabular}{|c|c|c|c|c|c|}
\hline $\begin{array}{l}\text { CAUSA DE } \\
\text { VARIAÇÃO }\end{array}$ & G.L & S.Q & Q.M & $\mathrm{F}$ & Interpr. \\
\hline SEM. & 1 & 10,0489 & 10,0489 & 4,3104 & * \\
\hline SUBS. & 2 & 2,6569 & 1,3285 & 0,5698 & ns \\
\hline COND. & 1 & 5,0027 & 5,0027 & 2,1459 & ns \\
\hline SEMXSUBS & 2 & 0,1956 & 0,0978 & 0,0420 & ns \\
\hline SEMXCOND & 1 & 0,169 & 0,0169 & 0,0072 & ns \\
\hline SUBSxCOND & 2 & 0,4142 & 0,2071 & 0,0888 & ns \\
\hline SEMxSUBSxCOND & 2 & 3,8095 & 1,9047 & 0,8170 & ns \\
\hline TRATAMENTOS & 11 & 22,1447 & 2,0132 & & \\
\hline BLOCOS & 2 & 8,5084 & 4,2542 & & \\
\hline RESÍDUO & 22 & 51,2887 & 2,3313 & & \\
\hline
\end{tabular}

Tabela 8. Quadro de análise de variância para emergência de plântulas de $P$. nitens do grupo $P+D$ experimento " $A$ " do projeto de semeadura direta aos 360 dias após a semeadura. Morro Agudo - SP, 2005

\begin{tabular}{|c|c|c|c|c|c|}
\hline $\begin{array}{l}\text { CAUSA DE } \\
\text { VARIAÇÃO }\end{array}$ & G.L & S.Q & Q.M & $\mathrm{F}$ & Interpr. \\
\hline SEM. & 1 & 12,7092 & 12,7092 & 7,6552 & * \\
\hline SUBS. & 2 & 2,0110 & 1,0055 & 0,6057 & ns \\
\hline COND. & 1 & 0,54551 & 0,5451 & 0,3284 & ns \\
\hline SEMXSUBS & 2 & 3,3062 & 1,6531 & 0,9957 & ns \\
\hline SEMXCOND & 1 & 0,2970 & 0,2970 & 0,1789 & ns \\
\hline SUBSxCOND & 2 & 0,6002 & 0,3001 & 0,1808 & ns \\
\hline SEMxSUBSxCOND & 2 & 4,6581 & 2,3291 & 1,4029 & ns \\
\hline TRATAMENTOS & 11 & 24,1270 & 2,1934 & & \\
\hline BLOCOS & 2 & 2,0024 & 1,0012 & & \\
\hline RESÍDUO & 22 & 36,5248 & 1,6602 & & \\
\hline
\end{tabular}


Tabela 9. Quadro de análise de variância para emergência de plântulas de $J$. cuspidifolia no grupo D do experimento "A" do projeto de semeadura direta aos 90 dias após a semeadura. Morro Agudo - SP, 2005

\begin{tabular}{|c|c|c|c|c|c|}
\hline $\begin{array}{l}\text { CAUSA DE } \\
\text { VARIAÇÃO }\end{array}$ & G.L & S.Q & Q.M & $F$ & Interpr. \\
\hline SEM. & 1 & 0,3268 & 0,3268 & 0,0867 & ns \\
\hline SUBS. & 2 & 2,0977 & 1,0488 & 0,2782 & ns \\
\hline COND. & 1 & 1,7030 & 1,7030 & 0,4518 & ns \\
\hline SEMXSUBS & 2 & 1,2677 & 0,6339 & 0,1681 & ns \\
\hline SEMXCOND & 1 & 0,1431 & 0,1431 & 0,0380 & ns \\
\hline SUBSXCOND & 2 & 2,7457 & 1,3729 & 0,3642 & ns \\
\hline SEMxSUBSxCOND & 2 & 1,1827 & 0,5914 & 0,1569 & ns \\
\hline TRATAMENTOS & 11 & 9,4668 & 0,8606 & & \\
\hline BLOCOS & 2 & 2,1904 & 1,0952 & & \\
\hline RESÍDUO & 22 & 82,9364 & 3,7698 & & \\
\hline
\end{tabular}

Tabela 10. Quadro de análise de variância para emergência de plântulas de $J$. cuspidifolia no grupo D do experimento "A" do projeto de semeadura direta aos 360 dias após a semeadura. Morro Agudo - SP, 2005

\begin{tabular}{lccccc}
\hline \multicolumn{1}{c}{ CAUSA DE } & G.L & S.Q & Q.M & F & Interpr. \\
\hline SEM. & 1 & 3,2942 & 3,2942 & 2,3742 & $\mathrm{~ns}$ \\
SUBS. & 2 & 8,3659 & 4,1830 & 3,0147 & $\mathrm{~ns}$ \\
COND. & 1 & 1,6857 & 1,6857 & 1,2149 & $\mathrm{~ns}$ \\
SEMxSUBS & 2 & 1,8552 & 0,9276 & 0,6685 & $\mathrm{~ns}$ \\
SEMxCOND & 1 & 0,3990 & 0,3990 & 0,2876 & $\mathrm{~ns}$ \\
SUBSxCOND & 2 & 0,1384 & 0,0692 & 0,0499 & $\mathrm{~ns}$ \\
SEMxSUBSxCOND & 2 & 1,2937 & 0,6469 & 0,4662 & $\mathrm{~ns}$ \\
TRATAMENTOS & 11 & 17,0322 & 1,5484 & & \\
BLOCOS & 2 & 3,8320 & 1,9160 & & \\
RESÍDUO & 22 & 30,5256 & 1,3875 & & \\
\hline
\end{tabular}


Tabela 11. Quadro de análise de variância para emergência de plântulas de J. cuspidifolia no grupo $P+D$ do experimento " $A$ " do projeto de semeadura direta aos 90 dias após a semeadura. Morro Agudo SP, 2005

\begin{tabular}{|c|c|c|c|c|c|}
\hline $\begin{array}{l}\text { CAUSA DE } \\
\text { VARIAÇÃO }\end{array}$ & G.L & S.Q & Q.M & $F$ & Interpr. \\
\hline SEM. & 1 & 1,8445 & 1,1845 & 1,2025 & ns \\
\hline SUBS. & 2 & 4,9325 & 2,4663 & 2,5038 & ns \\
\hline COND. & 1 & 16,7145 & 16,7145 & 16,9691 & ** \\
\hline SEMXSUBS & 2 & 4,6169 & 2,3084 & 2,3436 & ns \\
\hline SEMxCOND & 1 & 0,5852 & 0,5852 & 0,5941 & ns \\
\hline SUBSxCOND & 2 & 6,5419 & 3,2709 & 3,3208 & ns \\
\hline SEMxSUBSxCOND & 2 & 1,6277 & 0,8139 & 0,8263 & ns \\
\hline TRATAMENTOS & 11 & 36,2032 & 3,2912 & 3,2912 & \\
\hline BLOCOS & 2 & 9,9702 & 4,9851 & & \\
\hline RESÍDUO & 22 & 21,6699 & 0,9850 & & \\
\hline
\end{tabular}

Tabela 12. Quadro de análise de variância para emergência de plântulas de J. cuspidifolia no grupo $P+D$ do experimento " $A$ " do projeto de semeadura direta aos 360 dias após a semeadura. Morro Agudo SP, 2005

\begin{tabular}{|c|c|c|c|c|c|}
\hline $\begin{array}{l}\text { CAUSA DE } \\
\text { VARIAÇÃO }\end{array}$ & G.L & S.Q & Q.M & $\mathrm{F}$ & Interpr \\
\hline SEM. & 1 & 0,0747 & 0,0747 & 0,0629 & ns \\
\hline SUBS. & 2 & 1,1990 & 0,5995 & 0,5045 & ns \\
\hline COND. & 1 & 13,0562 & 13,0562 & 10,9872 & ** \\
\hline SEMxSUBS & 2 & 1,3082 & 0,6541 & 0,5504 & ns \\
\hline SEMXCOND & 1 & 0,8836 & 0,8836 & 0,7436 & ns \\
\hline SUBSxCOND & 2 & 32,6252 & 1,8128 & 1,5255 & ns \\
\hline SEMXSUBSXCOND & 2 & 0,4993 & 0,2496 & 0,2101 & ns \\
\hline TRATAMENTOS & 11 & 20,6465 & 1,8770 & & \\
\hline BLOCOS & 2 & 3,6487 & 1,8243 & & \\
\hline RESÍDUO & 22 & 26,1428 & 1,1883 & & \\
\hline
\end{tabular}




\section{REFERÊNCIAS BIBLIOGRÁFICAS}

ABRAHÃO, W.A.P.; MELLO, J.W.U. Fundamentos de pedologia e geologia de interesse no processo de Recuperação de uma área degradada. In: DIAS, L.E.; MELLO, J.W.U. (Ed.) Recuperação de áreas degradadas. Viçosa: Universidade Federal de Viçosa, 1998. p.15-26.

ALMEIDA, N.O. Implantação de matas ciliares por plantio direto utilizando-se sementes peletizadas. Lavras, 2004. 269p. Tese (Doutorado) - Universidade Federal de Lavras.

AMARAL, L.I.V.; PEREIRA, M. F. D. A.; CORTELAZZO, A. L. Germinação de sementes em desenvolvimento de Bixa orellana. Revista Brasileira de Fisiologia Vegetal, v.3, p.273-285, 2000

AMMER, C.; MOSANDL, R.; KATEB, H. E. Direct seeding of beech (Fagus sylvatica L.) in Norway spruce (Picea abies [L.] Karst.) stands-effects of canopy density and fine root biomass on seed germination Forest Ecology and Management. v.159, p.59-72, 2002.

ARONSON, J,; FlORET, C.; LE FlOC'H, E.; OVAlLE, C.; PONTANIER, R. Restauration et Réhabilitation des Écosystèmes Dégredés em Zone Arides et Semi-arides. Vocabulaire et le Concepts. In: PONTANIER, R.; HIRI, A.; AKRIMI, N.; ARONSON, J.; LE FLOC'H, E. L'Homme Peut - il Refaire ce qu’il a défait ? Paris: John Libbey Eurotext, 1995, p.11-29. 
BARBOSA, J.M.; SANTOS, M.R.O; PISCIOTTANO, W.A.; BARBOSA, L.M.; SANTOS, S.R.G. Estabelecimento de indivíduos de Inga uruguensis Hook. et Arn. a partir do plantio de sementes em uma área ciliar degradada, considerando diferentes condições de luz e umidade do solo. In: SIMPÓSIO INTERNACIONAL DE ECOSSISTEMAS FLORESTAIS, 2., Belo Horizonte. , 1996. Anais. Belo Horizonte: UFMG, 1996. p.291-293.

BARBOSA, J.M.; BARBOSA, L.M.; STROSS, S.R.; SILVA, T.S.; GATUZZO, E.H.; FREIRE, R.M. Recuperação de áreas degradadas a partir de sementes. In: CONGRESSO NACIONAL DE ESSÊNCIAS NATIVAS, 1., São Paulo, 1992. Anais. São Paulo: Instituto Florestal, 1992a, p.702-705.

BARBOSA, J.M.; BARBOSA, L.M.; STROSS, S.R; SILVA, T.S; GATUZZO, E.H.; FREIRE, R.M. Capacidade de estabelecimento de indivíduos de espécies da sucessão secundária a partir de sementes em sub-bosque de uma mata ciliar degradada do rio Moji Guaçu-SP. In: SIMPÓSIO NACIONAL DE RECUPERAÇÃO DE ÁREAS DEGRADADAS, Curitiba, 1992. Anais. Curitiba: UFPR, 1992b, p.400-406.

BARBOSA, L.M. Considerações gerais e modelos de implantação de recuperação de formações ciliares. RODRIGUES, R.R.; LEITÃO. FILHO, H. F. (Ed.) Matas ciliares (conservação e recuperação). São Paulo: EDUSP/FAPESP, 2000. p.209-312.

BARBOSA, L.M.; BARBOSA, J.M. Informações técnico-científicas sobre recuperação de áreas degradadas. Ecossistema, v.23, p.19-25, dez, 1998. 
BARBOSA, L. M.; MANTOVANI, W. Degradação Ambiental: Conceituação e bases para o repovoamento vegetal. In: RECUPERAÇÃO DE ÁREAS DEGRADADAS DA SERRA DO MAR E FORMAÇÕES FLORESTAIS LITORÂNEAS, São Paulo, 2000. p. 33-40. (Documentos Ambientais).

BARBOSA, L. M.; GISLER, C. V. T.; ASPERTI, L. M. Desenvolvimento inicial de oito espécies arbóreas em dois modelos de reflorestamento implantados em área de mata ciliar degradada em Santa Cruz das Palmeiras, SP. In: SIMPÓSIO NACIONAL DE RECUPERAÇÃO, 3., Ouro Preto, 1997b. Anais. Ouro Preto: SOBRADE, 1997b. p.437-445.

BARBOSA, L.M.; SERRA FILHO, R.; BARBOSA, J.M.; BARRETO, R.A.A.; ASPERTI, L.M.; MOURA, S.A.; CHITOLINA FILHO, R.; SEMACO, M. Desenvolvimento e implantação de modelos alternativos de recomposição vegetal com espécies nativas na Fazenda São Carlos Santa Cruz das Palmeiras - SP. São Paulo: Instituto de Botânica/SMA, 1993. 90p.

BARBOSA, L. M.; MACEDO, A. C.; DABUL, M. V.; BONOMI, V. L. R.; TRAPÉ, M. Z; KAGEYAMA, P. Y.; CATHARINO, E. L. M. Essências florestais Nativas de ocorrência no Estado de São Paulo, informações técnicas sobre: sementes, grupo ecológico, fenologia e produção de Mudas. MANUAL TÉCNICO, Unidade de Pesquisa e tecnologia de sementes do instituto de Botânica, São Paulo, 1997a. p? (Manual Técnico)

BARNETT, J.P.; BAKER, J.B. Regeneration methods. In: DURYEA, M.L.; DOUGHERTY, P.M. (Eds.). Forest regeneration manual. Dordrecht: Kluver Academic Publishers, 1991. cap. 3, p.35-50. 
BARRON, P.; DALTON, G. Direct seeding of native trees and shrubs in coastal environments. Journal of Coastal Research, v.12, n.4, p.1006-1008, 1996.

BARRON, P.; BISHOP, G.; DALTON, G. Regeneration of degraded mallee vegetation using direct seeding. Australian Journal of Soil and Water Conservation, v.9, p.40-44, 1996.

BAZZAZ, F.A.; PICKETT, S.T.A. Physiological ecology of tropical sucession: A comparative review. Annual Review Ecology System. v.11, p.287-310, 1980.

BERGSTEN, U. Pyramidal indentations as a micro site preparation for direct seeding of Pinus sylvestris L. Scandinavian Journal of Forest Research,. v.3, p.493-503, Jan., 1988.

BERTONCINI, A.P. Estrutura e dinâmica de uma área perturbada na terra indígena Araribá, Avaí (SP): Implicações para o manejo e a restauração florestal. Campinas, 2003. 162p. Tese (Doutorado) - Instituto de Biologia, Universidade Estadual de Campinas.

BOTELHO, S.A.; DAVIDE, A.C.; PRADO, N.S.; FONSECA, E.M.B. Implantação de mata ciliar. Belo Horizonte: CEMIG; Lavras: UFLA, 1995. 28p.

BRANDÃO, M. Plantas medicamentosas do Cerrado Mineiro. Informe Agropecuário, v.15, n.168, p.15-20, 1991.

BRENDER, E.V. Silviculture of Loblolly pine in the Georgia Piedmont Georgia: Forest Research Council, 1973. 74 p. (Report, 33). 
BROFAS, G.; KARETSOS, G. Revegetation of mining spoils by seeding of woody species on Ghiona Mountain, Central Greece. Land Degradation \& Development, v.13, n.6, p.461-467, Jul., 2002.

BRUM, E.S.; MATTEI, V.L.; MACHADO, A.A. Emergência e sobrevivência de Pinus taeda L. em semeadura direta a diferentes profundidades. Revista Brasileira de Agrociência, v.5, n.3. set.-dez p?, 1999.

BUDOWSKI, G. Distribution of tropical american rain forest species in the light of sucessional process. Turrialba, v.15, p.40-42, 1965.

BULLARD S.; HODGES J.D.; JOHNSON R.L.; STRAKA T.J. Economics of direct seeding and planting for establishing oak stands on old-field sites in the south. Southern Journal of Applied Forestry, v.16, p.34-40, 1992.

CABIN, R.J; WELLER, S.G.; LORENCE, D.H.; CORDELL, S.; HADWAY, L.J. Effects of microsite, water, weeding, and direct seeding on the regeneration of native and alien species within a Hawaiian dry forest preserve. Biological Conservation, v.104, p.181-190, Jul., 2002.

CAMARGO, J.L.C.; FERRAZ, I.D.K.; IMAKAWA, A.M. Rehabilitation of degraded areas of central Amazonia using direct sowing of forest tree seeds. Restoration Ecology, v.10, n.4, p.636-644, Dec., 2002.

CAMARGO, M.N.; KLAMT, E.; KAUFTMAN, J.H. Classificação de solos usada em levantamentos pedológicos no Brasil. Campinas. Sociedade Brasileira de Ciência do Solo, 1987. cap.12, p.11-33. (Boletim Informativo) 
CAMPBELL, T.E. Growth and development of loblolly and slash pines directseeded or planted on a cut-over site. Southern Journal of Applied Forestry, v.5, n.3, p.115-119, 1981.

CARPENEZZI, A.A.; COSTA, L.G.S.; KAGEYAMA, P.Y.; CASTRO, C.F.A. Espécies pioneiras para recuperação de áreas degradadas: a observação de laboratórios naturais. In: CONGRESSO FLORESTAL BRASILEIRO, 6., Campo do Jordão, 1990. Anais. São Paulo: SBS, 1990, p.216-221.

CARVALHO, P.E.R. Espécies florestais brasileiras: recomendações silviculturais, potencialidades e uso da madeira. Colombo: EMBRAPA-CNPF; Brasília: EMBRAPA-SPI, 1994. 640 p.

CLEMENS, J. Direct seeding of native woody plants. Landscape Australia, v.80, n.4, p.279-284, 1980.

COOPER, R.W.; SCHOPMEYER, C.S.; McGREGOR, W.H.D. Sand pine regeneration on the Ocala National Forest, (1959. 37p. USDA Forest Service, 30) (Research Paper).

COSTA, N. L.; PAULINO, V. T.; COSTA, R S. C.da. Efeito de micorrizas arbusculares e adubação com fosfato de rocha em Sesbania sesban. Ministério da Agricultura e do abastecimento. Rondônia: EMBRAPA-CPAF, Ago, 2001. p.1-4 (Circular Técnica, 194)

DAVIDE, A.C. Seleção de espécies vegetais para recuperação de áreas degradadas. In: SIMPÓSIO SUL-AMERICANO, 1, SIMPÓSIO NACIONAL DE RECUPERAÇÃO DE ÁREAS DEGRADADAS, 2., Foz do Iguaçu, 1994. Anais. Curitiba: FUPEF, 1994. p. 111-112. 
DAVIDE, A.C.; BOTELHO, S.A. Análise crítica dos programas de recomposição de matas ciliares em Minas Gerais. In: SIMPÓSIO MATA CILIAR: CIÊNCIA E TECNOLOGIA, Belo Horizonte, 1999. Anais. Lavras: UFLA/FAEPE/CEMIG, 1999. p.172-188.

DAVIDE, A.C.; FARIA, J.M.R.; PRADO, N.S. Recuperação de uma área ocupada por voçoroca, através do reflorestamento misto. In: SIMPÓSIO SUL-AMERICANO, 1, SIMPÓSIO NACIONAL RECUPERAÇÃO DE ÁREAS DEGRADADAS, 2, Foz do Iguaçu, 1994. Anais. Curitiba: FUPEF, 1994. p. 401-408.

DAVIDE, A.C.; FERREIRA, R.A.; FARIA, J.M.R., BOTELHO, S.A. Restauração de matas ciliares. Informe Agropecuário, v.21, n.207, p.65-74, nov.-dez. 2000

DAY, A. D.; LUDEKE, K. L. Direct seeding of tree species on copper mine wastes in the Southwestern United-States. Journal of Environmental Quality, v.9, n.2, p.304-306, 1980.

DALMACIO, M.V. BARANGAN, F. Direct seeding of Pinus keysia as affected by time of seeding, site preparation and seed coating. Forest Research Journal, v.1, p.215-222, 1976.

DERR, H.J; MANN Junior., W.F. Direct seeding pines in the South. Washington D.C.: U.S.D.A Forest Service, 1971. 68p.

DESLOW, J.S. Gap partioning among tropical rain forest trees. Biotropica, v.12, p.14-55, 1980. 
DIAS, L. E.; GRIFFITH, J. J. Conceituação e caracterização de áreas degradadas. In: DIAS, L.E.; MELLO, J.W.U. (Ed.) Recuperação de áreas degradadas. Viçosa: Universidade Federal de Viçosa, 1998. p. 1-7.

DOUGHERTY, P.M. A field investigation of the factors which control germination and establishment of loblolly pine seeds. Georgia: Brida, 1990. 5p. (Forestry Commission, 7).

DUNLAP, J.R.; BARNETT, J.P. Influence of seed size on germination and early development of loblolly pine (Pinus taeda L.) germinants. Canadian Journal of Forest Research, v.13, p.40-44, 1983.

DURINGAN, G.; NOGUEIRA, J.C.B. Recomposição de matas ciliares. IPEF, n.4, p.1-14, 1990.

ENGEL, V.L.; PARROTA, J.A. An evaluation of direct seeding for restoration of degraded lands in central São Paulo state, Brazil. Forest Ecology and Management. v.152, p.169-181, Sep., 2001.

ENGEL, V.L.; PARROTA, J.A. Definindo a restauração ecológica: tendências e perspectivas mundiais. In: KAGEYAMA, P.Y.; OLIVEIRA, R.E.; MORAES, L.F.D.; ENGEL, V.L.; GANDARA, F.B. (Ed.). Restauração ecológica de ecossistemas naturais. Botucatu: FEPAF, 2003. cap.1, p.3-26.

ENGEL, V.L.; MASSOCA, P.E.S.; PATRÍCIO, A.L; MUNHOZ, M.O. Implantação de espécies nativas em solos degradados através da semeadura direta. www.cemacufla.com.br/trabalhospdf/ (22 abr. 2004). 
FARAH, F.T. Favorecimento da regeneração de um trecho degradado de uma floresta estacional semidecidual. Campinas, 2003. 213p. Dissertação (Mestrado) - Instituto de Biologia, Universidade Estadual de Campinas.

FARIA, J.M.R. Comportamento de espécies florestais em diferentes sítios de plantios e adubações de plantio. Lavras, 1996. 108p. Dissertação (Mestrado) - Universidade Federal de Lavras.

FARIA, J.M.R.; DAVIDE, A.C.; BOTELHO, S.A. Comportamento do guapuruvu (Schizolobium parahyba Leguminosae-Caesalpinoideae) e cássia verrugosa (Senna multijuga Leguminosae-Caesalpinoideae) em área degradada, sob dois regimes de nutrição. In: SIMPÓSIO SUL-AMERICANO, 1.,SIMPÓSIO NACIONAL DE RECUPERAÇÃO DE ÁREAS DEGRADADAS, 2., Foz do Iguaçu, 1994. Anais. Curitiba: FUPEF, 1994. p. 499-508.

FERREIRA, R. A. Estudo da semeadura direta visando à implantação de Matas Ciliares. Lavras, 2002. 138p. Tese (Doutorado) - Universidade Federal de Lavras.

FERREIRA, C. A. G.; TAUK-TORNISIELO, S. M.; CHAVES, M. M. F. Behavior of bracatinga (Mimosa scabrella) and sesbania (Sesbania sesban) in degraded areas by disposal residue from bauxite processing. HOLOS Environment, v.2., n.2, p.156-173, 2002.

FINGER, C.A.G.; SCHNEIDER, P.R.; GARLET,A.; ELEOTÉRIO,J.R.; BERGER,R. Estabelecimento de povoamentos de Pinus elliottii Engelm pela semeadura direta a campo. Ciência Florestal, n.1, v.13, p.107-13, 2003. 
FLEMING, R.L.; MOSSA, D.S. Direct seeding of black spruce in northwestern Ontario: seedbed relationships. Forestry Chronicle, v.70, n.2, p.151-158, Mar.-Apr., 1994.

FLEMING, R. L. MOSSA, D. S. Direct seeding of black spruce in northwestern Ontario - temporal changes in seedbed coverage and receptivity. Forestry Chronicle, v.71, n.2, p.219-227, Mar.- Apr., 1995.

FLORES-AYLAS, W. W. Desenvolvimento inicial de espécies arbóreas em semeadura direta: efeito de micorriza e fósforo. Lavras, 1999. 81p. Dissertação (Mestrado) - Universidade Federal de Lavras.

FRANCO, A.A.; CAMPELLO, E.F.C.; SILVA; E.M.R.; FARIA, S.M. de; Revegetação de solos degradados: Seropédica, Brasília: EMBRAPACNPBS, 1992. 8p. (Comunicado Técnico).

FRASER, J.W. Operational direct seeding trials with black spruce on upland cutovers. Ontario: Guty ,1981. 34p. (Canadian Forest Science)

FOWLER, D.B. Seeding equipament: Winter wheat production manual. Yorkton: Ducks Unlimited Canada, 1995. p.601-621.

GANDOLFI, S.; RODRIGUES, R.R. Recomposição de florestas nativas: algumas perspectivas metodológicas para o Estado de São Paulo. In: CURSO DE RECUPERAÇÃo DE ÁREAS DEGRADADAS, 3., Curitiba, 1996. Anais. Curitiba: FUPEF, 1996. p.83-100.

GOMEZ-POMPA, A. Posible papel de la vegetación secundária en la evolución de la flora tropical. Biotrópica, v.3, p.125-135, 1971. 
GÓMEZ-POMPA, A.; VÁSQUES-YANES, C. Sucessional studies of a rain forest in México. In: WEST, D.C.; SHUGART, H.H.; BOTKIN, D.B. (Ed.) Forest succession. New York: Springer-Verlag, 1981. p.246-266.

GOOSEM, S.; TUCKER, N.I.J. Repairing the rain forest. Cairns: Wet Tropics Management Authory, 1995. 72p.

GRATZER, G.; RAI, P.B. Density-dependent mortality versus spatial segregation in early life stages of Abies densa and Rhododendron hodgsonii in Central Bhutan. Forest Ecology and Management. v.192, p.143-159, May., 2004.

GROOT, A. ADAMS, M. J. Direct seeding black spruce on Peatlands - 5th-year results. Forestry Chronicle, v.70, n.5, p.585-592, Sep., 1994.

GULDIN, R.W. Regeneration costs using container-grown southern pine seedlings. (Research Paper, 187 USDA Forest Service 187, 1983. 29p.)

HAZEL, D. W.; SMITH, M.D.; FRANKLIN, C. Direct-seeding of loblolly pine in the North Carolina Piedmont: four-year results. Southern Journal of Applied Forestry, v.13, n.2, p.91-93, May, 1989.

$\mathrm{HAU}, \mathrm{C}$. The establisment and survival of native trees on degraded hillside in Hong Kong. Hong Kong, 1999. 175p. Thesis (Ph.D) - Univerty of Hong Kong.

HAYWOOD, J.D.; GRELEN, H.E. Twenty years of prescribed burning influence the development of direct-seeded longleaf pine on a wet pine site in Louisiana. Southern Journalof Applied Forestry, v.24, n.2, p.86-92, 2000. 
HERRERA, M.A.; SALAMANCA, C.P.; BAREA, J.M. Inoculation of woody legumes with selected arbuscular mycorrhizal fungi and rhizobia to recover desertified Mediterranem ecosytems. Applied and Environmental Microbiology, v.59, p-129-133, 1993.

HETH, D. Spot sowing of mediterranean pines under shelter. Tree Planters' Notes, v.34, n.4, p.23-27, 1983.

HOBBS, R.J.; HARRIS, J.A. Restoration ecology: repairing the eath's ecosystems in the new millenium. Restoration ecology, n.2, v.9, p.239-246, June, 2001.

HODGKINS, E. J. A study of direct-seeding depths for loblolly pine. Journal of Forestry, v.64, n.5, p.317-322, Feb., 1966.

HULTÉN, H. Root deformation of forest seedlings. In: NORDIE SYMPOSIUM, Swedish, 1982 Proceedings Stocolmo Swedish University of Agricultural Science, 1982. p.11.

HUSS, E. On the quality of forest tree seed and other factors affecting the sowing result. Medd. Statens Skogsforskningsinstitut, v.46, p.15 1956.

IVANAUSKAS, N.M.; RODRIGUES, R.R.; NAVE, A.G. Aspectos ecológicos de uma mata de brejo em Itatinga - SP: florística, fitossociologia e seletividade de espécies. Revista brasileira de Botânica. n.2, v.20, p.139-153, 1997.

KAGEYAMA, P.Y.; CASTRO, C.F.A. Sucessão secundária, estrutura genética e plantações de espécies arbóreas nativas. IPEF, n.41/42, p.83-93, 1989. 
KAGEYAMA, P.Y.; MENDES, F.B.G. Revegetação de áreas degradadas - alta diversidade de espécies. In: SIMPÓSIO IPEF, 6., Piracicaba, 1996. Anais. Piracicaba: IPEF Universidade de São Paulo, 1996. p.21-29.

KAGEYAMA, P.Y.; GANDARA, F.B. Recuperação de áreas ciliares. In: RODRIGUES, R.R.; LEITÃO FILHO, H.F. (Ed.) 2000. Matas Ciliares (conservação e recuperação). São Paulo: EDUSP/FAPESP, p.249-269.

KAGEYAMA, P.Y.; GANDARA, F.B. Restauração e conservação de ecossistemas tropicais. In: CULLEN Junior., L.; RUDRAN, R.; VALLADARES-PADUA, C. (Ed.). Métodos de estudos em biologia da conservação \& manejo da vida silvestre. Curitiba: UFPR, cap. 14, 2003. p.383-395.

KAGEYAMA, P.Y.; CASTRO, C.F.A.; CARPANEZZI, A.A. Implantação de matas ciliares: estratégias para auxiliar à sucessão secundária. In: SIMPÓSIO SOBRE MATA CILIAR, São Paulo, 1989. Anais. Campinas: Fundação Cargil, p.130-143.

KAGEYAMA, P.Y.; BIELA, L.C.; PALERMO Junior., A. Plantações mistas com espécies nativas com fins de proteção a reservatório. In: SIMPÓSIO FLORESTAL BRASILEIRO, 6., Campos do Jordão, 1990. Anais. São Paulo: SBS, p.109-112.

KAGEYAMA, P.Y.; GANDARA, F.B.; OLIVEIRA, R.E. Biodiversidade e restauração da floresta tropical. In: KAGEYAMA, P.Y.; OLIVEIRA, R.E.; MORAES, L.F.D.; ENGEL, V.L.; GANDARA, F.B. (Ed.). Restauração ecológica de ecossistemas naturais. Botucatu: FEPAF, cap.2, 2003. p.2748. 
KAGEYAMA, P.Y.; FREIXADAS, V.M.; GERES, W.L.; DIAS, J.H.P.; BORGES, A.S. Consórcio de espécies nativas de diferentes grupos sucessionais em Teodoro Sampaio-SP. Revista do Instituo Florestal, v.4, p.527-533, 1992.

KAGEYAMA. P.Y.; SANTARELLI, E.; GANDARA, F.B.;GONÇALVEX, J.C.; SIMIONATO, J.L; ANTIQUERA, L.R.; GERES,W.L. Revegetação de áreas degradadas: modelos de consorciação com alta diversidade. In: SIMPÓSIO SUL - AMERICANO, 1., SIMPÓSIO NACIONAL DE RECUPERAÇÃO DE ÁREAS DEGRADADAS, 2., Foz do Iguaçu, 1994. Anais. Curitiba: FUPEF, 1994. p.569-576.

KINNUNEN, K. Scots pine sowing on barren mineral soils in western Finland. Folia Forestalia, n.531, p.1-24, 1982.

KINNUNEN, K. Effect of substratum, date and method on the post-sowing survival of Scots pine. Folia Forestalia, n.785, p.I-45, 1992.

KISSMANN, K. G.; GROTH, D. Plantas infestantes e nocivas. São Paulo: BASF, 1995. 683p. (Manual de Identificação)

KNIGHT, A.J.P.; BEALE, P.E.; DALTON, G.S. Direct seeding of native trees and shrubs in low rainfall areas and on non-wetting sands in South Australia. Agroforestry Systems, v.39, n.3, p.225-239, Apr., 1998.

KÖEPPEN, W. Climatologia. México, D.F: Fondo de cultura econômica, 1948. $478 p$.

KULMANN, Y.S.; KUHN, E. A flora do Distrito de Ibiti. São Paulo: Secretaria de Agricultura - Instituto Botânico, 1947, 221p. 
LÄHDE, E. The effect of seed-spot shelters and cold stratification on pine (Pinus sylvestris L.). Folia Forestalia, n. 196, p.1-16, 1974.

LAMB, D.; PARROTA, J.; KEENAM, R.; TUCKER, N. Rejoining habitats remmants: restoring degraded rainforest lands. In: LAURANCE, W.; BIERREGAARD Junior., R.O. (Ed.) Tropical forest remnants: ecology, management, and conservation of fragmented communities. Chicago: The University of Chicago Press, 1997. p.336-385.

LOHREY, R.E.; JONES Junior., E.P. Natural regeneration and direct seedingf. In: SYMPOSIUM THE MANAGED SLASH PINE ECOSSYSTEM, Florida, 1981: Proceedings. Florida: Bisa, 1981, p.183-193.

LONG, J.M. Roots system form and its relationship to growh in young planted conifers. In: ROOT FORM OF PLANTED TREES SYMPOSIUM, Victoria, 1978 Proceedings Victoria: MCR, 1978. v.8, p.222-234.

LORENZI, H. Árvores brasileiras: manual de identificação e cultivo de plantas arbóreas nativas do Brasil. Nova Odessa: Plantarum, 1992. 352p.

LUGO, A. Tree plantations for rehabilitating damaged forest lands in the tropics. In: WALI, M.K. (Ed.). Ecosystem rehabilitation: ecosystem analysis and synthesis. The Hague: SPB Academic Publishing, 1992. p.247-255.

MACEDO, A.C.; KAGEYAMA, P.Y.; COSTA, L.G.S. Revegetação : matas ciliares e de proteção ambiental. São Paulo: Fundação Florestal, SMA, 1993. $26 p$.

MANN Junior, W.F.; DERR, H.J. Guide for direct-seeding slash pine. (USDA Forest Service 12, 1964. 27p.). (Research Paper, 12) 
MANN Junior., W. F. 10 years experience with direct-seeding in south. Journal of Forestry, v.66, n.11, p.828-830, Jun.,1968.

MANDAL, T.; NIELSEN, N.E. An improved low-input method for establishing calliandra hedgerows on small-scale farms in western Kenya. Agroforestry System, v.60, p.227-231, 2004.

MARTINS, S.V. Recuperação de matas ciliares. Viçosa: Aprenda Fácil, 2001. 149p.

MARTINS, S.V.; RODRIGUES, R.R. Gap-phase regeneration in semideciduous mesophytic forest, southeastern Brazil. Plant Ecology, v.63, n.1, p.51-62, 2002.

MARTINEZ-RAMOS, M. Claros, ciclos vitales de los árboles tropicales y regeneración natural de las selvas altas perenifólias. In: GOMEZ-POMPA, A.; DEL AMO, R.S. (Ed.) Investigaciones sobre la regeneracion de selvas altas em Vera Cruz México. Alhambra Mexicana: INIRB, 1985. p.191-239.

MATTEI, V.M. Comparação entre semeadura direta e plantio de mudas produzidas em tubetes, na implantação de povoamentos de Pinus taeda L. Curitiba, 1993. 149p. Tese (Doutorado) - Universidade Federal do Paraná.

MATTEI, V.M. Preparo de solo e uso de protetor físico, na implantação de Cedrella fissilis Vell. e Pinus taeda L., por semeadura direta. Revista Brasileira de Agrociência, v.1, n.3, p.133-136, set.-dez.,1995.

MATTEI, V.M. Avaliação de protetores físicos em semeadura direta de Pinus taeda L. Ciência Florestal, v.7, n.1, 91-100, 1997. 
MATTEI, V.M. Materiais de cobertura em semeadura de Pinus elliottii Engelm e P. taeda L., diretamente no campo. Revista Brasileira de Agrociência, v.4, no 1, 64-68, jan.-abr., 1998.

MATTEI, V.M.; ROSENTHAL, M.D. Semeadura direta de canafístula (Peltophorum dubium (Spreng.)Taub.) no enriquecimento de capoeiras. Revista Árvore, v.26, n.6, p.649-654, 2002.

MATTEI, V.M.; ROMANO, C.M.; TEIXEIRA, M.C.C. Protetores físicos para semeadura direta de Pinus elliottii Engelm. Ciência Rural, v.31, n.5, p.775780, 2001.

MONTALVO, A.M.; McMILLAN, P.A.; ALLEN, E.B. The relative importance of seeding method, soil ripping, and soil variables on seeding success. Restoration Ecology, v.10, n.1, p.52-67, Mar., 2002.

MUZZI, E.; ROFFI, F.; SIROTTI, M.; BAGNARESI, U. Revegetation techniques on clay soil slopes in Northern Italy. Land Degradation \& Development. v.8, p.127-137, Jul., 1997.

NAVE, A. G. Banco de sementes autóctone e alóctone, resgate de plantas e plantio de vegetação nativa na fazenda Intermontes, Município De Ribeirão Grande, SP, Piracicaba, 2005. 231p. Tese (Doutorado) - Escola Superior de Agricultura"Luiz de Queiroz" - Universidade de São Paulo.

NILSON, M.E.; HJÄLTÉN, J. Covering pine-seeds immediately after seeding: effects on seedlings emergence and on mortality through seed-predation. Forest Ecology and Management. v.176, p.449-457, May, 2003. 
NOLTE, D.L. Efficacy of selected repellents to deter deer browsing on conifer seedlings. International Biodeterioration \& Biodegradation, v.42, p.101107, 1998.

NOLTE, D.L.; BARNETT, J.P. A repellent to reduce mouse damage to longleaf pine seed. International Biodeterioration \& Biodegradation, v.45, p.169$174,2000$.

OZÓRIO, T.F. Potencial de uso da serrapilheira na recuperação de áreas degradadas por mineração de ferro. Mariana-MG. Viçosa, 2000. 62p. Dissertação (M.S.) - Universidade Federal de Viçosa.

OWUOR, B. O.; GUDU, S.; NIANG, A. Direct seeding of Sesbania sesban for green manure in agroforestry systems - a short communication. Agroforestry Systems, v.152, n.1, p.23-25. Dec., 2001

PASCOAL, W.C.; NAKANO, J.A. Tecnologia e aplicação de herbicidas préemergentes em reflorestamento. In: SEMINÁRIO SOBRE PLANTAS DANINHAS E O USO DE HERBICIDAS EM REFLORESTAMENTO, Rio de Janeiro, 1988. Anais. Rio de Janeiro: ABRACAVE, 1988. p.1-11.

PARKER, V.T. The scale of sucessional model and restoration objetives. Restoration Ecology, n.4, v.5, p.301-306, 1997.

PARROTTA, J.A. Secondary forest regeneration on degraded tropical lands: the role of plantations as "foster ecosystems". In: LIETH, H.; LOHMANN, M. (Ed.). Restoration of tropical forest ecosystem. The Hague: Kluwer Academic Publishers, 1993. p.63-73. 
PARROTTA, J. A.; KNOWLES, O.H. Restoration of tropical Moist forest on bauxite-mined lands in Brazilian Amazon. Restoration Ecology, v.7, n.2, p.103-116, Jun., 1999.

PARROTTA, J. A.; KNOWLES, O.H. Restoring tropical forests on bauxite mined lands: lessons from the Brasilian Amazon. Ecological Engineering, v. 17, n.2/3, p.219-239, 2001.

PICKETT, S.T.A; PARKER, V.T.; FIEDLER, L. The new paradigm in ecology: Implications for conservation biology above the species level. In: FIEDLER, L.; JAIN, S.K. (Ed.). Conservation biology: the theory and practice of nature conservation, and management. New York: Chapman and Hall, 1992. p.65 68.

PIMM, S.L. Community stability and structure. In: SOULÉ, M.E. (Ed.), Conservation ecology: the science of scarcity and diversity. Massachusetts: Biology, 1986. 584p.

PINÃ RODRIGUES, F. C. M.; FIGIOLIA. M. B. Informações práticas sobre sementes de espécies arbóreas. 1992. 48p.

PITELLI, R.A.; KARAM, D. Ecologia das plantas daninhas e sua interferência em culturas florestais. In: SEMINÁRIO SOBRE PLANTAS DANINHAS E O USO DE HERBICIDAS EM REFLORESTAMENTO, Rio de Janeiro, 1988. Anais. Rio de Janeiro: ABRACAVE, 1988. p.1-20.

POMPÉIA, S. L.; PRADELLA, D. Z. A.; MARTINS, S. E.; SANTOS, R. C.; DINIZ, K. M. A semeadura aérea na Serra do Mar em Cubatão. Revista Ambiente, São Paulo, v.3, n.1, p.13-19, 1989. 
PUTMAN, W. E.; ZASADA, J. C. Direct seeding techniques to regenerate white spruce in interior Alaska. Canadian Journal of Forest Research, v.16, n.3, p.660-664, Jun., 1986.

REIS, A.; ZAMBONIM, R.M.; NAKAZONO, E.M. Recuperação de áreas florestais degradadas utilizando a sucessão e as interações plantaanimal. São Paulo: Conselho Nacional da Reserva da Biosfera, 1999. 42p.

REITZ, R. Flora Ilustrada Catarinense - Solanaceae. Itajaí: Herbário Barbosa Rodrigues, 1966. 321p.

REITZ, R. Flora Ilustrada Catarinense - Leguminosae-Mimosoidae. Itajaí: Herbário Barbosa Rodrigues, 1979. 304p.

RIBEIRO, G.T. Uso de herbicida pré-emergente em Eucalyptus spp. na região do Cerrado. In: SEMINÁRIO SOBRE PLANTAS DANINHAS E O USO DE HERBICIDAS EM REFLORESTAMENTO, Rio de Janeiro, 1988. Anais. Rio de Janeiro: ABRACAVE, 1998. p.1-12.

RODRIGUES, B.N.; ALMEIDA, F.S. Guia de herbicidas. 4.ed. Londrina: Londrina, 1998. 648p.

RODRIGUES, J.J.V.; COELHO, J.P.; KARAN, D.; ZANÚNCIO, I.; TAKADA, H.M Efeitos de doses crescentes de oxyfluorfen no controle de plantas daninhas na cultura do Eucalyptus. In: SEMINÁRIO SOBRE PLANTAS DANINHAS E O USO DE HERBICIDAS EM REFLORESTAMENTO, Rio de Janeiro, 1988. Anais. Rio de Janeiro: ABRACAVE, 1998. p.1-11. 
RODRIGUES, R.R. Colonização e enriquecimento de um fragmento florestal urbano após a ocorrência de fogo, Fazenda Santa Eliza, Campinas, SP: Avaliação temporal da Regeneração Natural (66 meses) e do crescimento (51 meses) de 30 espécies florestais plantadas em consórcios sucessionais. Piracicaba, 1999. 167p. Tese (livre docência) - Escola Superior de Agricultura "Luiz de Queiroz", Universidade de São Paulo.

RODRIGUES, R.R.; GANDOLFI, S. Recomposição de florestas nativas:princípios gerais e subsídios para uma definição metodológica. Revista Brasileira de Horticultura Ornamental, n.2, v.1, p.4-15, 1996.

RODRIGUES, R.R.; GANDOLFI, S. Restauração de Florestas Tropicais: Subsídios para uma definição metodológica e indicadores de avaliação e monitoramento. In: DIAS, L.E., MELLO, J. V. (Ed.) Recuperação de áreas degradadas. Viçosa: Universidade Federal de Viçosa, 1998. p. 204-215.

RODRIGUES, R.R.; GANDOLFI, S. Conceitos, tendências e ações para recuperação de florestas ciliares. In: RODRIGUES, R.R; LEITÃO. FILHO, H. F. (Ed.). Matas ciliares (conservação e recuperação), São Paulo: EDUSP/FAPESP, 2000. p. 235-247.

RODRIGUES, R.R.; NAVE, A.G. Heterogeneidade florística das matas ciliares. In: RODRIGUES, R.R; LEITÃO. FILHO, H. F. (Ed.). Matas ciliares (conservação e recuperação), São Paulo: EDUSP/FAPESP, 2000. p. 159167. 
RODRIGUES, R.R.; LEITÃO FILHO, H.F.; CRESTANA, M.S.M. Revegetação do entorno da represa de abastecimento de água do município de Iracemápolis, SP. In: SIMPÓSIO NACIONAL DE RECUPERAÇÃO DE ÁREAS

RODRIGUES, R. R.; GANDOLFI S.; NAVE. A. G. Programa de Adequação Ambiental das Propriedades Rurais da Jardest Açúcar e Álcool Ltda. Piracicaba: LERF/ESALQ/USP, 2004. 120p. (Relatório técnico ambiental)

RODRIGUES, R. R.; GANDOLFI S.; NAVE. A. G.; ARAKI, D. F. Programa de Adequação Ambiental das Propriedades Rurais da Fundação Sinhá Junqueira. Piracicaba: LERF/ESALQ/USP, 2003. 110p. (Relatório técnico ambiental)

RODRIGUES, R. R.; GANDOLFI S.; NAVE. A. G.; FARAH, F. T.; NOVAES, E.; PIROMAL, R. A. S.; ARAKI, D. F, BUFO, L. V .B. Programa de adequação ambiental das propriedades rurais da Cia. Açucareira Vale do Rosário Fase II. Piracicaba: LERF/ESALQ/USP, 2002. 110p. (Relatório técnico ambiental)

ROZZA, A.F. Manejo e regeneração de trecho degradado da floresta estacional semidecidual: Reserva Municipal de Santa Genebra, Campinas, SP. Campinas, 2003. 132p. Tese (Doutorado) -Instituto de Biologia, Universidade Estadual de Campinas.

SALVADOR, J.L.G. Considerações sobre as matas ciliares e a implantação de reflorestamentos mistos as margens de rios e reservatórios. São Paulo: CESP, 1989. 15p. 
SANCHOTENE, M. C. C. Frutíferas nativas úteis à fauna na arborização urbana. Sagra, Porto Alegre. 1989. p.?

SANTARELLI, E.G. Recuperação de mata ciliar: seleção de espécies e técnicas de plantio. In: CURSO DE RECUPERAÇÃO DE ÁREAS DEGRADADAS, 3. Curitiba, 1996. Anais. Curitiba: FEPEF, 1996. p.101-105.

SANTOS JUNIOR, N. A. Estabelecimento inicial de espécies florestais nativas em sistema de semeadura direta. Lavras, 2000. 96p. Dissertação (Mestrado) - Universidade Federal de Lavras.

SERPA, M.R. Avaliação de diferentes materiais de cobertura no estabelecimento de plantas de Pinus taeda, L. no sistema de semeadura direta. Pelotas, 1999. 49p. Dissertação (Mestrado) - Universidade Federal de Pelotas.

SETZER, J. Contribuição para o estudo do Clima do Estado de São Paulo. São Paulo: Escolas Profissionais Salesianas, 1946. 86p.

SIQUEIRA, A.C.M.F.; NOGUEIRA, J.C.B. Essências brasileiras e sua conservação genética no Instituto Florestal de São Paulo. In: CONGRESSO NACIONAL SOBRE ESSENCIAS NATIVAS, 2., São Paulo, 1992. Anais. São Paulo: Instituto Florestal, 1992. p.1187.

SIQUEIRA, L.P. Monitoramento de áreas restauradas no interior do Estado de São Paulo, Brasil. Piracicaba, 2002. 116p. Dissertação (Mestrado) - Escola Superior de Agricultura "Luiz de Queiroz", Universidade de São Paulo.

SMITH, D.M. The pratice of silviculture. 8.ed. New York: John wiley, 1986. $527 p$. 
SORREANO, M.C.M. Avaliação de aspectos da dinâmica de florestas restauradas, com diferentes idades. Piracicaba, 2002. 145p. Dissertação (Mestrado) - Escola Superior de Agricultura "Luiz de Queiroz", Universidade de São Paulo.

SOUZA, F.M; BATISTA, J.L.F. Restoration of seasonal semideciduous forests in Brazil: influence of age and restoration design on forest structure. Forest Ecology and Management, v.191, p.185-200, 2004.

SOUZA, L.S.; VELINI, E.D.; MAIOMONI-RODELLA, R.C.S. Efeito alelopático de plantas daninhas e concentrações de capim-braquiária (Brachiaria decumbens) no desenvolvimento inicial de eucalipto (Eucalyptus grandis). Planta Daninha, v.21, n.3, p.343-354, 2003.

SOUZA, S.C.P. M. Análise de alguns aspectos de dinâmica florestal em uma área degradada no interior do parque estadual do Jurupará, Ibiúna, São Paulo. Piracicaba, 2002. 88p. Dissertação (Mestrado) - Escola Superior de Agricultura "Luiz de Queiroz", Universidade de São Paulo.

STANTON, N. Herbivore pressure on two types of tropical forests. Biotropica. v.7, p.8-11, Abr. 1975.

SUN, D.; DICKINSON, G. R. Direct seeding for rehabilation of degraded lands in north-east Queensland. Australian Journal of Soil and Water Conservation, n.8, v.4, p.14-17, Dec.,1995.

SUN, D.; DICKINSON, G. R. The competition effect of Brachiaria decumbens on the early growth of direct-seeded trees of Alphitonia petriei in tropical north Australia. Biotropica, v.28, n.2, p.272-276, Jun., 1996. 
SUN, D.; DICKINSON, G.R.; BRAGG, A.L. Direct seeding of Alphitonia petriei (Rhamnaceae) for gully revegetation in tropical northern Australia. Forest Ecology and Management, v.73, n.1-3, p.249-257, May, 1995.

TEIXEIRA, M.I.J.G. Estudo fitossociológico de floresta estacional semidecidual e de cerrado no Município de Patrocínio Paulista, SP. Jaboticabal, 2003. 79p. Dissertação (Mestrado) - Faculdade de Ciências Agrárias e Veterinárias, "Universidade Estadual Paulista Julio de Mesquista Filho".

THOMAZ, S.K.; MAIA, S.M.; BORSSATO, I.; TERADA, M. A opção para o uso de pré-emergente em reflorestamento no Vale do Rio Doce. In: SEMINÁRIO SOBRE PLANTAS DANINHAS E O USO DE HERBICIDAS EM REFLORESTAMENTO, Rio de Janeiro, 1988. Anais. Rio de Janeiro: ABRACAVE, 1988. p.1-12.

TOLEDO, F.F.; MARCOS FILHO, J.M. Manual das sementes: tecnologia da produção. São Paulo: Ceres, 1977. 223p.

TOledo, R.E. B.; DINARDO, W.; BEZUTTE, A.J.; ALVES, P. L.C.A.; PITELLI, R.A. Efeito da densidade de plantas de Brachiaria decumbens Stapf sobre o crescimento inicial de mudas de Eucalyptus grandis W.Hill ex Maiden. Scientia Forestalis, n. 60, p. 109-117, dez. 2001.

TOUMEY, J.W.; KORSTIAN, C.F. Seeding and planting in the pratice of forestry. New York: John Wiley, 1967, pt.2, cap.6, p.205-218.

VALTANEN, J.; ENGBERG, M. The result from Kainuu and Pohjamaa the loughed-area reforestation experiment begun during 1970-1972. Folia Forestalia, v.686, p.5-42, Oct., 1987. 
VAN DAMME, L. Microsite soil compaction enhances establishment of directseeded Jack pine in Northwestern Onitario. Northwestern Journal Applied Forestry, v.9, n.3, p.107-112, 1992.

VAN DAMME, L.; BAX, H. The Development of Better Direct Seeding Techniques through Applied-Research. Forestry Chronicle, v.67, n.3, p.268270, 1991.

VARMOLA, M.; KOLSTROM, T.; MEHTATALO, E. The effect of release cutting on the growth and external quality of the dominant trees in a Pinus sylvestris stand established by spot sowing. Scandinavian Journal of Forest Research, v.13, n.5, p.151-159, 1998.

VENNING, J. Direct seeding: assessing its potential. Trees Nature Research, v.27, p.26-28, 1985.

WALDRON, R.M. Direct seeding in Canada 1900-1972. In: DIRECT SEEDING SYMPOSIUM, Ottawa, 1974 Proceeding. Ottawa: Canadian Forest Service, 1974. 178p.

WENNSTRÖM, U., BERGSTEN, U.; NILSSON, J-E. Mechanised microsite preparation and direct seeding of Pinus sylvestris in boreal forests - a way to create desired spacing at low cost. New Forests, v.18, n.2, p.179-198, 1999.

WENNSTRÖM, U.; BERGSTEN, U.; NILSSON, J-E. Early seedling growth of Pinus sylvestris (L.) after sowing with a mixture of stand and orchard seed in dense spacing. Canadian Journal of Forest Research ,v.31, n.7, p.11841194, 2001. 
WHITMORE, T.C. On pattern and process in forest. In: NEWMAN, F. I. (Ed.). Special publication 1. Series of the British Ecologycal Society. Oxford: Blackwell Scientific Publications, 1982. p.45-59.

WILLOUGHBY, I.; CLAY; D.; DIXON F. The effect of pre-emergent herbicides on germination and early growth of broadleaved species used for direct seeding. Forestry, v. 76, p.93-94, Nov., 2003

WINSA, $\mathrm{H}$. Influence of rain shelter and site preparation on seedling emergence of Pinus-Sylvestris L. after Direct Seedling. Scandinavian Journal of Forest Research, v.10, n.2, p.167-175, 1995.

WINSA, H.; BERGSTEN, U. Direct seeding of Pinus sylvestris using microsite preparation and invigorated seed lots of different quality: 2-year results. Canadian Journal of Forest Research, v.24, n.1, p.77-86, Jan., 1994.

WINSA, H.; SAHLÉN, K. Effects of seed invigoration and microsite preparation on seedling emergence and establishment after direct sowing of Pinus sylvestris L. at different dates. Scandinavian Journal of Forest Research, v.16, p.422-428, Sep., 2001.

WOODS, K.; ELLIOTT, S. Direct seeding for forest restoration on abandoned agricultural land in northern Thailand. Journal of Tropical Forest Science, v.16, 248-259, Apr., 2004.

YOUNG, T.P. Restoration ecology e conservation biology. Biological Conservation, v.92, p.73-83, 2000. 